\title{
Consumer 4.0 \\ on the food market
}

Edited by Ewa Jerzyk, Anna Rogala, Renata Nestorowicz

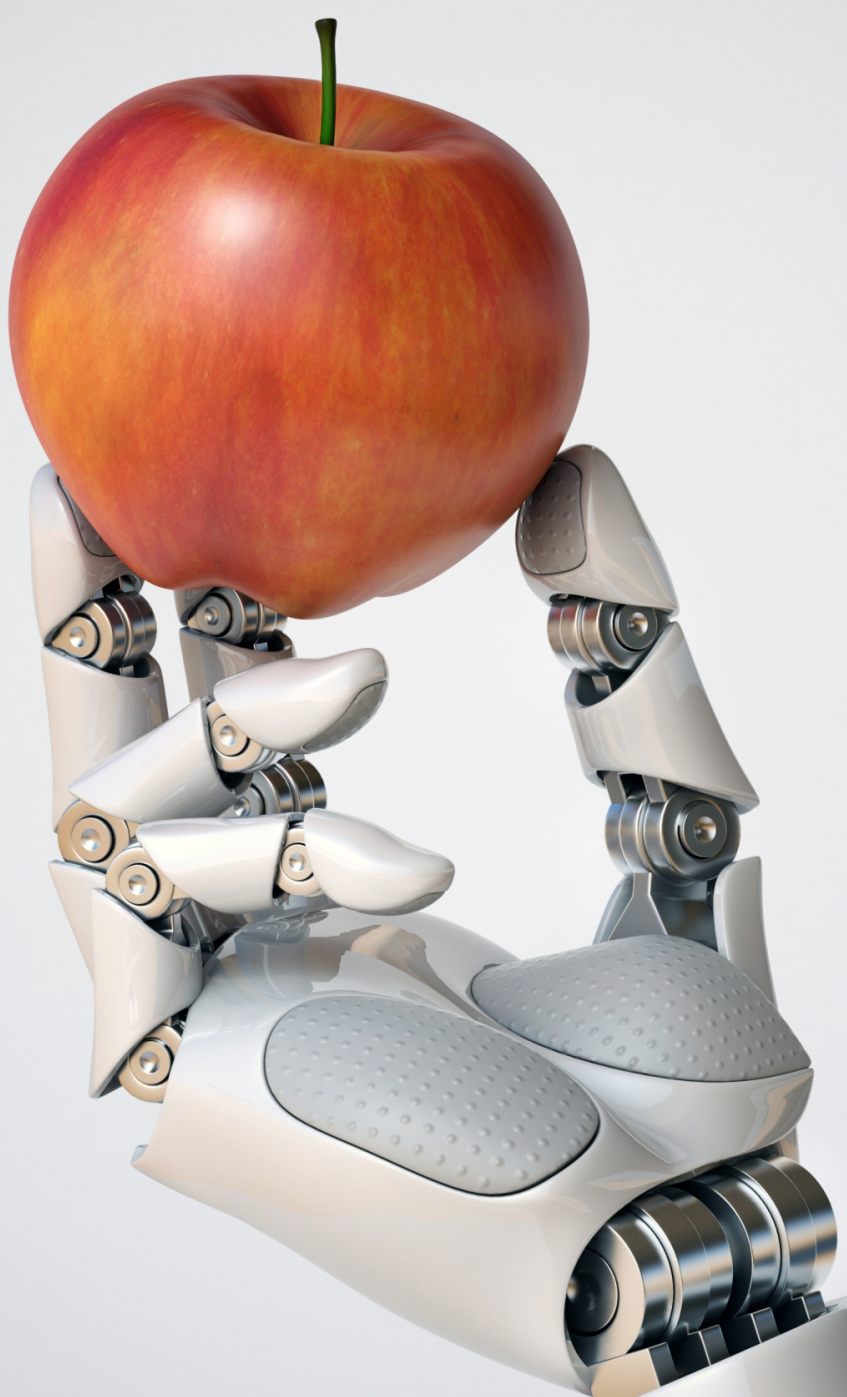


Consumer 4.0 on the food market 



\section{Consumer 4.0 on the food market}

Edited by Ewa Jerzyk, Anna Rogala, Renata Nestorowicz 
Reviewer: dr hab. Paweł Bryła, prof. UŁ

Ministry of Science and Higher Education Republic of Poland
Co-financed by the "Doskonała nauka" program of the Minister of Science and Higher Education

Copyright (c) by Poznań University of Economics and Business, Poznań 2021

Cover photo: Koya979/stock.adobe.com

ISBN 978-83-7986-399-0

https://doi.org/10.12657/9788379863990

Bogucki Wydawnictwo Naukowe

ul. Górna Wilda 90

61-576 Poznań

www.bogucki.com.pl

biuro@bogucki.com.pl

Printed in Poland by PerfektDruk 


\section{Contents}

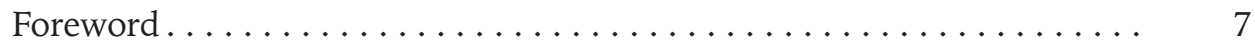

Henryk Mruk

Marketing challenges on the food market.............. 11

Anna Rogala, Ewa Jerzyk, Renata Nestorowicz

Opportunities and threats related to the use of the IoT in the food market from the consumer's perspective $\ldots \ldots \ldots \ldots \ldots \ldots \ldots \ldots \ldots \ldots \ldots \ldots \ldots$

Marcin Gurtatowski

Possibilities of the application of VR technology for shaping the awareness and pro-ecological attitudes of food consumers

(a case study of the Pollinator Park application) . . . . . . . . . .

Meletios I. Niros, Angelica I. Niros

Digital loyalty strategies during the pandemic that payoff:

empirical evidence from the Greek food market . . . . . . . . . . . . .

Mirosława Pluta-Olearnik

The role of social media influencers in building a brand's authority in the food market.

Marcin Adam Antoniak

Nutrition and health claims (2000-2020): a systematic literature review .

Sylwia Majcher

Consumer attitudes to health and nutrition claims $\ldots \ldots \ldots \ldots \ldots \ldots$

Mirosław Pacut

Consumers' preferences on the food market in selected European countries . 



\section{Foreword}

The behaviour patterns of modern consumers are dynamically changing, largely due to the fast development of technology and the appearance of solutions based on its application. The popularity of the Internet - not only as a medium of communication between food sellers and consumers or among consumers, but also as the space for seeking information, for the evaluation of products available on the market, and the place for shopping - has contributed to the gradual virtualization of life, which we observe particularly in developed countries. It has become increasingly common to include technological solutions, first, in consumers' decision-making processes and purchasing practices and, second, in food manufacturing and distribution processes. The food market, which until recently had been perceived in terms of the traditional trade formula and the application of standard communication forms, has been going through deep changes which are manifested in the ongoing process of digitalization.

Businesses operating in this sector at the different stages of the supply chain are becoming increasingly interested in the application of modern technologies. Solutions from the field of the Internet of Things (IoT), artificial intelligence and extended reality are being adopted by manufacturers and retailers, as well as by companies which deal with logistics process management. Not only do they facilitate managing production, transport and sales, but they also meet the expectations of consumers 4.0, who - thanks to such solutions - gain access to information concerning the details of the manufacturing process, carbon footprints, or the influence on the health or, more generally, well-being of an individual. We also observe the growing popularity of mobile apps, which collect, analyse and send information between the consumer and the manufacturer, and between the manufacturer and other entities involved in the whole supply chain. Consequently, digitalization in the food market is a dynamic process.

In this monograph, we attempt to identify phenomena that indicate the specific nature of modern consumer behaviour on the food market, taking into consideration how their activity is influenced by technology, on the one hand, and by trends related to concern about the wellbeing of individuals and the natural environment, on the other. The individual chapters of the monograph reveal the complexity of factors determining dietary patterns and the activities which help to shape desirable behaviours in the sphere of food consumption. The contents presented in eight chapters are based on the analysis of the authors' own sources, data obtained in the course of empirical research conducted by the authors, and case studies.

The monograph begins with a paper devoted to the determinants of the food market. A holistic analysis of the functioning of this market leads to the 
conclusion that it faces big changes arising from the necessity of ensuring sustainable development. The author recognizes the end of the traditionally defined economic growth, which was based on the use of natural resources. The text expresses the conviction that the pace of economic development cannot be more important than the choice of the way that leads to it. Sometimes, a slower journey means reaching home more safely. Climate change and the pandemic have led to irreversible transformations in the sphere of food buyers' behaviours; they disturbed supply chains, triggered social unrest and the migrations of populations, which may soon acquire a global character. The global plans for food market management devised by the EU or UN require bigger involvement on the part of state governments and local authorities. The pace of technological development is a great deal faster than the pace of changes occurring in people's minds. Thus, when planning the implementation of the Internet of Things, artificial intelligence or extended reality solutions, one should take this aspect in consideration.

The next chapter discusses the opportunities and threats related to the use of the IoT from the food consumer's perspective. In the introduction, the authors present changes occurring in consumer behaviour, which are a consequence of the development of modern technologies. Consumer 4.0, as the symbol of the Industry 4.0 revolution, uses modern technologies, such as digital, personalized communication, and adheres to certain values which are important from the point of view of his or her social identity. The IoT and the IoF (Internet of Food) are technologies which can support modern consumers in their eating habits, provide better access to information and encourage more responsible behaviours, including the reduction of food wastage. On the other hand, they create threats related to security, loss of privacy, costs, or vague principles associated with sharing information.

The next text presents a case study on the use of virtual reality for shaping the pro-ecological attitudes of consumers. The case of the VR application "Pollinator Park" concerns the reduction in the population of pollinating insects caused by environmental pollution. The shortage of pollinators results in the lower yields of main crops, an increase in their prices and limited food availability. Pollinating insects not only have a positive influence on the reproduction of arable plants, but they also affect biodiversity. To protect the population of insect pollinators, behavioural economics proposes solutions referring to experience marketing and appealing to consumers' emotions. One of these options is the presented interactive experience in the extended reality of the vision of the world in 2050.

The fourth chapter of the monograph has an empirical character and presents the example of the Greek food market, which - just like other markets - has gone through serious turbulence during the pandemic. The authors focus on the e-consumers of food, whose segment has significantly increased in these difficult times. The study focuses on e-consumers' purchasing intentions, moderated by openness to technological innovations (i.e., digital adoption) and the perceived risk of infection.

The issue of the influence of the digital world on consumers' dietary behaviours is also addressed in the next chapter, which includes an analysis of three 
cases of the use of influencer marketing for building a food brand image on social media. The study confirms the considerable degree to which influencer-experts affect consumers who follow healthy trends, and the pandemic even intensified this impact.

Health is an important motivating factor of consumers' nutritional choices. For a long time now, we have observed buyers' propensity to purchase food on the basis of information concerning the benefit of a specific nutrient (e.g., fibre, protein, vitamin C) or the impact on health. In recent years, we have witnessed fast growth in the number of food products including nutritional and health claims. This issue is addressed in the next two chapters of the book (chapters six and seven). The influence of such declarations on consumer buying behaviours is an interesting subject discussed by a number of researchers, which is confirmed by the presented literature review. In turn, the empirical verification of the effectiveness of these declarations does not always prove their positive impact on purchasing intentions.

The monograph ends with the chapter which diagnoses the strength of healthy trends in selected European countries (France, Germany, Poland, Russia, Italy and the United Kingdom). Natural ingredients, calorie content, reduced fat, sugar or salt content, and the recommendations of a health promotion organization are important priorities of consumer buying decisions. However, they are often only declared preferences, as demonstrated by the growing percentage of overweight and obese people and the increase in diet-related illnesses.

This monograph does not exhaust the subject of consumer behaviour on the food market 4.0. Such a study would require more in-depth and diverse analyses, based largely on the results of research conducted in interrelated subject areas. In this monograph, we attempted to outline the biggest challenges that enterprises operating in the market have to face as a consequence of the ongoing social, environmental and technological changes. 



\title{
Henryk Mruk
}

\section{Marketing challenges on the food market}

\begin{abstract}
Purpose: The aim of this paper is to provide a critical overview of the changes in relation to consumer behaviour, marketing activities and new trends concerning the food market. Design/methodology/approach: Source information is taken from other papers. Those papers include source literature, the opinions of people in charge of different companies, statistical information and direct observation. The research methodology includes logical reasoning, trend analysis, critical assessment of published concepts, and comparative analysis.

Findings: The fast pace of social and economic changes necessitates looking for some successful means of balancing the development of the food market. Both the coronavirus pandemic and threats to the climate are challenges connected with the research into consumer behaviour, modifying distribution channels and establishing efficient marketing communication. Advances in neuroscience and knowledge of human nature allow actions to be undertaken that will satisfy both the suppliers and buyers of food products. The global economy, including the food market, is facing new challenges. They concern some critical perception of the limits of economic growth and the care for sustainable development. They also involve looking for some instruments that would help to rationalise consumption. The coexistence of different generations of consumers increases the need to build successful marketing campaigns. Regardless of the actions taken by food suppliers, there is a solid ground for experimenting with actions undertaken on a state level.
\end{abstract}

Keywords: marketing on the food market, consumer behaviour, communication on the food market, food distribution

\section{Introduction}

In 2021, the world, including the food market, was faced with a lot of new problems. Their severity was highlighted by the results of the coronavirus pandemic and climate changes. For the first time in its history, the global economy suffered a shock on such a big scale as the result of the attack of a new virus. It slowed down economic growth, increased the pace of introducing new technologies and 
changed the level and the structure of countries' spending. At the same time, the awareness of societies regarding threats connected to ecological and climate changes has increased. The result of these and many other factors are changes to the customer's behaviours on the food market, disturbances in supply chains and the functioning of distribution channels, as well as increasing debt and social unrest, including migration.

The purpose of this paper is to provide a critical overview of the changes in relation to consumer behaviour, marketing activities, and new trends concerning the food market. The research is focused on individual consumers, households, and companies. Source information is taken from other papers. Those papers include source literature, opinions of people in charge of different companies, statistical information and direct observation. The research methodology applies logical reasoning, trend analysis, critical assessment of published concepts, and comparative analysis. Considerations focus on consumers, behaviours, and the most important elements of the food market.

\section{The dynamics of environmental changes}

Both the societies and economies of different countries, which are becoming increasingly interlinked, have to face constant changes. The pandemic made the VUCA model especially useful for adjusting business models to dynamic changes on the market (Kok J. van den Heuvel, 2019). VUCA is a term derived from the military, and it describes the specificity of war situations: volatility, uncertainty, complexity and ambiguity. On the one hand, a long-term, strategic view of the markets is of the utmost importance, while on the other it is necessary to improve business operations in terms of keeping the right level of current effectiveness (Mintzberg, 2019). Changes, insecurity and ambiguity demand flexibility and the right speed when making market decisions. Equally important is the implementation of the UN's 2030 Agenda and the concept of the 2050 European Green Deal. Making decisions is the responsibility of the managers of the entities operating on the market. Making decisions at the right time becomes key (Pink, 2018). The world has limited capacities to successfully manage the global economy and people. Different countries have their own resources and goals, and it is difficult to prepare and introduce one global plan for the development of the food market. There is no doubt that the world is becoming an increasingly global place. Nevertheless, at the same time there are more and more extremes. There are countries that are able to provide their citizens with sufficient food, but there are also countries where people are starving. The same applies to technology, education and medicine. We know that the world is developing, but we do not know how those differences between societies will increase. We have to face some paradoxes and there are still more questions than answers that are based on facts and the use of objective scientific methods (Hatalska, 2021). 


\section{The myth of unlimited economic growth}

Around the middle of the twentieth century, the methodology of determining the level of Gross Domestic Product was established. It has become a kind of a fetish for most countries. Previously, F. Taylor had improved the ways in which work performance was measured. This was also a fetish connected to the development of industry. Observations of the natural world can highlight some limitations. Trees, animals and people are not able to overcome many of them. Of course, we may live in a world of fiction, but only an objective approach will guarantee the correct observation of reality (Cedestrom and Spicer, 2016). A person who breaks the rules of proper nutrition loses the ability to function in the environment and shortens their life. Persuading governments and societies that we may increase the level and dynamics of GDP without limitations is a false assumption. Social and economic processes should be free from myths and stereotypes. Such theories appear in the critical approach to consumerism and are strengthened by the considerations based on some scientific methods and the techniques of logical reasoning (Hickel, 2021). Regardless of the development of theories, some countries have stopped using such indicators as the level and dynamics of GDP, as well as GDP per capita. They are being replaced by other indicators which show the level of people's happiness and the quality of life. In the face of the pandemic and climate issues, it may be right to prioritize qualitative goals instead of quantitative ones (Frankl, 2019). From the point of view of consumer behaviour, there is another myth which assumes that price is the only factor that influences the decision making process. In the economic sphere, price is usually the determinant of quality, although some wider context should also be taken into account on a global scale. An example may be an offer from a food products distributor concerning the possibility to import any food products for a consumer. Let's assume that a single food product will be imported from Australia to Poland. The high price of such a product may result from the costs of transport, the preservatives used, customs etc. At the same time, long transport times and distances, as well as protective measures, may significantly decrease the quality of the product. As a result it is increasingly in the consumer's interest to buy local products, since this shortens the way "from the field to the consumer".

\section{Household earnings and the food market}

According to Engel's law, as a household's income increases, the percentage spent on food products decreases. At the same time, the absolute amount spent on food consumption increases, as well as the amount in terms of quantity. The correlation between the level of spending on food products and the level of income is scientifically documented. Taking a wider approach, we should be aware of how complex the abovementioned correlation is. There are different factors, sometimes hard to measure, that influence consumer behaviour. Of course, of importance are the distribution of income and the share of the so-called middle 
class within it. It is worth mentioning two issues while considering the level and distribution of income. The first one is the likelihood of real income increase. This is influenced by the level of nominal income and inflation. At the turn of 2022, new challenges related to inflation arise. Both the pandemic and climate change are leading to a rise in the costs of energy. Also political factors should be taken into account. Nevertheless, a logical analysis, based on some forecasting methodologies, leads to detailed conclusions (Tetlock, 2017). It is very likely that the period of development of the world economy, based on past costs of energy and resources, has come to an end. At the end of 2021, we may see an increase in inflation. Poland has one of the highest inflation rates in Europe - about 7\% at the end of the year. In 2022 the costs of energy will also increase. The result of those changes will be a slower pace of real income growth and even its decrease for some households.

Another issue is concerned with the controversies associated with the middle class. H. Rosling states reasons for the growing importance of the middle class (Rosling, 2018). He highlights the improvement of the overall health of societies in most countries of the world, while comparing it to the changes in income distribution among different groups. This shows that the significance of the middle class is growing in most economies. Nevertheless, there is a theory which illustrates the distribution of household income with the use of the hourglass model. According to this theory, the purchasing potential of the middle class is decreasing (Peretti, 2019). The model assumes that the differences between people with high and low levels of income are increasing. In terms of absolute value, only a small percentage of the population holds half $(50 \%)$ of the world's wealth (the owners of the biggest companies). On the other end is the wealth of the rest of the world, consisting of people with only a slightly higher income than the social minimum. There is no doubt that both the global pandemic and the scale of migration will drive changes in the distribution of household income. It will translate into changes in the form and structure of expenditures on food products.

\section{Excess economy and consumer behaviour}

It is hard to estimate how long Homo sapiens has lived on our planet and to determine the changes in living conditions precisely. There is no doubt that most of that time was spent on looking for food, and subsequently on producing it. In Poland, until 1989 society lived in the conditions of a shortage economy. The proof of this was the introduction of food stamps at the end of the communist era. We may assume that the end of the twentieth century was the time when the shortage economy was replaced by the excess economy. Food products became more accessible. Improving technological trends translates into extending the shelf life of food products. Easier access to food and the safety of its storage in refrigerators allowed the level of consumption to be increased. One result of those changes is the larger number of people suffering from being overweight and obesity. The development of medicine allows the negative effects of the overconsumption of 
food to be reduced, but this seems to be a vicious circle, as it leads to both social and economic issues.

Let us turn to a simulation of the market of meat products and its development. In 2019, the average meat consumption per person worldwide was $33.7 \mathrm{~kg}$. In the same year, the level of meat consumption in the USA was $101.6 \mathrm{~kg}$. The overall consumption in the world was 225 million tons, as of 2019. For Africa, it was only $5 \mathrm{~kg}$ per person and in India $3.7 \mathrm{~kg}$. Our simulation concerns the assumption that the average worldwide meat consumption will achieve the same level as in the USA. That would mean an increase of $67.9 \mathrm{~kg}$ per person (101.6 minus 33.7). There are about 7.6 billion people in the world. This means that increasing the world's supply of meat to the level of $101.6 \mathrm{~kg}$ per person would demand another 516 million tons of meat. This would be twice the production of 2019. Such simplified simulations (we ignore the waste of meat in these calculations) show that it is necessary to introduce a lot of changes in order to provide the right conditions for living on our planet. The production of meat and the demand for water cause air pollution. We may doubt if it would be possible for our planet to produce, in an ecological manner, such a huge amount of meat. Calculations, although more scientific than real, show how big the threat is. The idea of development without any limitations is just a utopia. It is necessary to take actions that will introduce changes to the way the food market operates in the world. It is also worth noting that changes in human brains are incomparably slower than changes in production technology and food processing (Ohme, 2017).

\section{Rationality overshadowed by emotions}

The development of economics based on the homo oeconomicus paradigm - the rational approach to making market decisions - assumed that consumers behave in a rational manner. That supposition was called into question during the second part of the twentieth century. The breakthrough was the publication of a study by D. Kahneman and A. Tverski on the limited rationality of consumers' decisions (Kahneman, 2012). Further development of that research stream, sometimes called "behavioural economics", has turned the spotlight on human nature and decision-making processes. The idea that decisions are made on a rational basis has been revealed to be a fiction. It is legitimate to create different impulses that make consumers increase the rationality of their behaviour (Thaler, 2018). A special example that illustrates the gap between rational behaviour and emotions may be the reluctance to follow recommendations concerning the need to get vaccinated during the pandemic. Limited success has been achieved by appealing to the results of scientific research, information provided by doctors, and data about the death toll caused by the virus. In a world dominated by social media, rumour, conspiracy theories and other factors that are hard to identify, consumer behaviour is easily influenced (Shiller, 2021). This increases the information chaos and makes it more difficult to make decisions that could better serve single consumers, households and society as a whole. The demand side of the food market 
is becoming more and more complex, nuanced and less predictable. This poses more and more challenges for governments, food production companies, distributors and individual consumers. At the same time, the demand for research on the operation of the food market is increasing. On the one hand we need detailed research concerning producers, technology distributors, and logistics, but on the other we also need overall analysis - made from the perspective of our planet and people's well-being.

\section{The evolution of marketing theory}

Throughout the 100 years of its existence, marketing theory has changed in response to changes in its environment. The transition from the shortage to the excess economy inspired changes to the business model. Consumers' needs were prioritised over production capacities. This helped to develop the marketing approach to shaping the offer of products, pricing policy, distribution channels and means of communication with the market. Food producers and distributors enhanced the instruments of marketing management available to them. The gap between producers' knowledge and consumers' awareness increased. The growing level of asymmetric information raises some questions concerning the balance between buyers and sellers (Nestorowicz, 2017). Both the results of the research from behavioural economics and the need to optimize government spending have become incentives for applying the marketing concept on a macroeconomic scale. Marketing instruments may be successfully used by governments to limit the asymmetry of information between food consumers and suppliers. Using those marketing tools proves to be successful also in many other areas, which was presented in relation to the social sphere (Bregman, 2020). It is in the common interest of producers, suppliers, governments and consumers to use marketing instruments properly, so as to achieve sustainable development of the economy. On the producers' market, including the producers and distributors of food products, the rule called "caveat emptor" (Let the buyer beware) is supported by the rule caveat venditor (Let the seller beware) (Pink, 2014). An important catalyst of those changes are new technologies and the ability for every participant in the food producers' market to access information.

\section{Common responsibility for the development of the global food market}

The complexity of the food market results from the connection between producers, the industry, distributors, logistic companies, the authorities and consumers. The globalization of the economy also results in longer supply chains (Banaszyk and Kauf, 2021). It is a paradox that some subsidies are given to meat producers in order to make them limit the supply of their products and prevent excess on the market. On the other hand, there are places where people are starving. It is a big challenge on a global scale to constantly work on enhancing the operation 
of companies from the perspective of people's well-being. Technological advances allow the shelf life of many food products to be extended. The work on producing food in laboratories is also at an advanced level. The distributors improve their storage systems and food packaging to minimize losses. The responsibility for the effectiveness of the food market also has to be taken by countries and consumers. The governments may use many tools in order to change consumer behaviour and influence the decisions made by them. Knowledge about human nature allows them to use regulations that will be beneficial for all the subjects of the market. We may recall here both federal and local actions. Different non-profit organizations that support the sustainability of food products also have some positive influence. In some countries, government positions were created that are aimed at supporting the process of rationalizing consumers' decisions (Thaler, 2019). An example may be one experiment that focused on stacking meals on the shelves of school canteens, which helped to decrease the level of obesity among students (first, students could choose healthy dishes, and later, when they had trays full of healthy options, unhealthy meals were offered). It is also worth mentioning that some actions were taken by national institutions which helped to reduce the level of asymmetric information. For example, we may mention here The Institute for Food and Nutrition (Instytut Żywności i Żywienia) and The Institute of Public Health (Instytut Zdrowia Publicznego). In the era of social networking sites, influencers and celebrities, information concerning food and nutrition based on research and proof may be a point of reference for consumers. There is no way to totally eliminate risk, but we may restrict it by promoting institutions that are aimed at presenting information based on scientific research. Despite such actions, however, consumers should take responsibility for their decisions. It is also an area that requires their common involvement.

\section{The determinants of consumer behaviour}

There are a lot of papers that describe the factors that influence consumer behaviour. It is the focus of many research studies, both general and detailed. Knowledge of the determinants of the decision-making process changes over time, in accordance with the capabilities of performing different research (Bartosik-Purgat, 2018). It is hard to systematically write about this area, since it is very intricate and varied. But it is worth looking at some of those aspects from the point of view of the knowledge gained thanks to neuroscience. This mostly concerns conclusions from the research into brain activity that help us to learn more about human nature. It is also connected with the abovementioned area of behavioural economics. One of the myths that should be refuted is that consumers have well-developed willpower (Gazzaniga, 2013). Such solutions as a "smorgasbord" or "all you can eat for 5 dollars" decrease the rationality of behaviours. Artificial intelligence or the Internet of Things may help to improve consumers' nutrition standards. A fridge becomes a customer and may order as much food as is necessary for the consumer. Artificial intelligence may send some signal to inform 
a consumer that no more food should be eaten, because there are enough food products on his or her plate. A trolley that recognizes a consumer may be a guide with a list of proposed products (Lee, 2019). Artificial intelligence is able to recognize the freshness of bananas based on their colour and automatically decrease their price. Improving the rationality of actions may be built on knowledge of different thinking traps. Knowledge concerning the way that the left and right cerebral hemispheres function may be very useful. The more incentives there are that stimulate the brain, the higher the activity shown in its left hemisphere. In such cases, a less important role is played by intuition, which belongs to the right hemisphere. First thoughts, decisions, choices are usually beneficial for consumers. They also increase their level of satisfaction. But if we neglect our left hemisphere, which is responsible for analytical thinking (price, adverts, packaging, the place where products are stored), it may lower our ability to rationalise food consumption. Another trap is connected with sugar. Our brain likes it and increases our appetite for sweet products. It is a kind of non-logic loop - sweet products, becoming overweight, diabetes, insulin, shorter life. Another example of a trap are visual stimuli. To increase the rationality of consumers' decisions we may present a cooked piece of meat. It will be coloured in grey. At the same time different meat products (ham, sausage), tempt a consumer with their red colour, which comes from the use of different additives. Also the size of a plate in a "smorgasbord" restaurant will influence the amount of food placed on it. Moreover, we have to mention some fictions which have their roots in stereotypes. One of them is the tradition of leaving some food on one's plate, which leads to food waste.

\section{The evolution of the forms of food shopping}

The pandemic became a catalyst for changes in the place and form of food shopping. The first issue concerns the way we pay for goods. Cash will be eliminated at an increasingly fast rate. This is in the best interest of many subjects of the market. Paying by card, by smartphone or smartwatch eliminates the pain that our brain associates with paying in cash. Consumers have greater comfort when they pay by some electronic means. Some governments aim to eliminate cash from payments. This will increase the control over the economy, limit the number of thefts and the extent of the black market, but may also increase the level of spending on food products, which leads to food waste. The second change that accelerated during the pandemic was the focus on online shopping. Consumers have more and more incentives around them that may consume their time. People like entertainment, having fun, feeling emotions and gathering memories (Dukaj, 2019). Ordering food via the Internet allows them to save time. It also improves their security, especially during new waves of the virus. Broad possibilities to spend time in an attractive manner become an incentive to shorten the time spent on shopping. It has led to the elimination of some large area stores in favour of smaller shops (like Lidl, Dino). Even on the relatively traditional market 
of pharmacies, in 2021 Poland saw the highest dynamics of the OTC sales of medicines and medical products via the Internet.

Greater opportunities for consumers to spend time in an attractive way has led to an increasing demand for catering services. People are social beings and tend to spend their time in the company of other people. This was especially visible during the pandemic, when there were some social protests against restrictions concerning the freedom to meet in restaurants or coffee bars. It is also the part of the food market that is connected to the high growth dynamics. Connecting tourism and travelling to different places increases the demand for catering services (hotels, leisure centres etc.).

In relation to the distribution area and the forms of purchase, we may point to changes taking place on the institutional market, such as in the number of companies providing and ordering food in the form of lunch boxes or other readymade meals (HoReCa sector). Changes to the B2B sector are also interesting and worth mentioning. Traditional subjects that used to supply food products to independent stores (e.g. Selgros) are being replaced by some virtual platforms. This also changes the traditional borders between subjects - a retail shop becomes a subject of the B2C sector.

Notwithstanding the abovementioned trends, people are becoming more and more interested in preparing meals as a way of spending free time. An additional element is here consumers' possibility to educate one another in terms of the relations between consumption, quality of products, thermal processing and health. It also includes new segments of consumers. An example here may be people who identify themselves as vegetarians or vegans.

Establishing some good food consumption habits is easier when we get support from other people. There are new ways of supporting consumers on the market, in the form of dieticians, advisers and coaches who help consumers make decisions and change their habits.

\section{Communication and its role on the food market}

The fast pace of changes happening in the world demands an elastic approach to different aspects of management and marketing on the food market. We need an elastic approach to offers and creativity in making decisions, offering new products, building the brand's position or communication with partners and the environment. In the twenty-first century, in addition to the pandemic, we have to critically look at different opinions. A more precise look at the societies of Europe allows us to see many important differences in terms of consumer behaviour on the food market. The Greeks believe that the Mediterranean diet has a beneficial impact on their health and the quality of life. The Italians tend to eat abundant dinners. The Germans drink a lot of beer, and the French a lot of wine. In every European society, the average lifespan is relatively high. Maybe our bodies have the ability to adapt to different conditions. As a result, different countries have their own solutions, traditions and trends. One of them may be an 
increasing awareness of consumers, which may make the exchange processes the basis, in terms of the circular economy (Olejniczuk-Merta and Noga, 2020). In the decision-making process involving management decisions made by subjects of the food market, it is legitimate to develop the techniques of creative thinking (Garbarski, 2021). They may have a significant role to play in creating the value that plays and increasing role in satisfying consumers (Mazzuccato, 2021). We should maintain some distance when choosing marketing research as the way to get information on the market. It is worth developing experiments and drawing conclusions. A new approach to the business model is required. Installing parcel lockers close to groceries allows the effect of synergy to be achieved by different subjects. The Booksy platform allows people to remotely make appointments with subjects providing services on the food market. Consumers' experiences are more and more significant (Bova, 2018).

We should adopt a cautious attitude to McGregor's hierarchy of needs, also called Maslow's hierarchy of needs. To be sure, Maslow should be recognised for defining people's needs. But their grouping into a "pyramid" happened later. The pandemic shows that we should critically look at the concept of the pyramid. Homo sapiens creates harmony, not hierarchy when it comes to satisfying needs. A special place should be given to social needs. This was also proved in this paper. Trade, as a special form of goods exchange, is about relations between people. The common consumption of food is more important than eating alone. Receptions or business negotiations are elements of food consumption connected to the building of social relations. New technologies (e.g. Żappka) allow food products to be purchased without other people's presence. But the development of restaurants results from social needs. A value for consumers is also the ability to communicate with shop staff. Notwithstanding the development of discount chains, in Poland there is still a large number of small shops. The number of restaurants has also been increasing. Interpersonal social communication is built on the basis of consuming and purchasing food products.

Regardless of the direct communication with customers and relations that are present in teams of employees, it is necessary to invest in communication with the surrounding environment. Apart from information concerning offers, promotions, discounts and sales, it is also important to communicate some values. Consumers like having fun and that is why using different promotional methods is very important. Consumers value situations where they can save some money. Distributors use different methods to attract consumers' attention.

In the twenty-first century, more and more market subjects, including the food market, come from the area of Corporate Social Responsibility (CSR). Decreasing the amount of sugar in food products demands communication. The effectiveness of such actions demands adjusting the form and the content of communication to meet the needs of different generations. Traditional media (TV, radio, press) are more effective in the relation to Generation BB or Generation X (people born between 1945 and 1970). The situation is different when it comes to Generation Y or Z, where social networking sites, photos, short videos and podcasts are always more important. During the pandemic, information about 
safety and hygiene may be important for consumers. People favour messages that are easy to understand and familiar. It is a good idea to base them on context communication, which means providing information adjusted to the segment and consumers' generation. In Poland in 2021, notable success was attained by the communication concerning the "Ekipa" ice-cream brand, which was aimed at the youngest group in society. Consumers also like stories. They may be created by using different narratives which are focused on a brand or a shop. An important aspect of consumers' quality of life is attendance at different events. This is connected to the abovementioned emotions that are important for building relations with brands.

\section{Conclusion}

People that manage different subjects of the food market, as well as all managers, are interested in getting precise advice and guidelines in order to increase the effectiveness of their actions. In order to do achieve this aim, we have to understand that the right decisions are made in the right head. They are the effect of personal experiences, gained knowledge, talent or inspiration. The idea that we should wait for some ready-made conceptions and advice is a fiction that we should reject. It is worth investing in education or experiences.

Nevertheless, it is also worth behaving in accordance with one's rules and values. During the era of social networking sites, it is very easy to denounce false and non-ethical actions. Authenticity, transparency and simplicity are pillars on which we should build partner relations with our customers. The offer of local products and ecological food should be sincere. Also worth considering is building a strong brand of a product, retailer, wholesaler etc. The use of pictures, short videos and voice mail may also be useful. It is worth considering the use of different tools which are described as the tools of "marketing automation". They are connected to personalizing the offer - both for consumers and business partners.

The pandemic has caused many changes to the marketing environment. We may expect that the number of hybrid solutions will increase. It may increase the demand for online events and education. We should also take a close look at Generation Z, which widely uses TikTok to communicate. They expect short messages, provided through videos and micro-influencers. Cookies or celebrity endorsements are becoming less effective. Authenticity and creativity are areas that demand special attention, and the development of skills. In the marketing management process, it will be important to connect directed, strategic thinking with flexibility in making operational decisions on the quickly changing market.

\section{References}

Banaszyk P., Kauf S., Szołtysek J., 2021. Logistyka jako czynnik dobrostanu. PWE, Warszawa. 
Bova T., 2018. IQ wzrostu. MT Biznes, Warszawa.

Bregman R., 2020. Homo sapiens. Ludzie są lepsi, niż myślisz. Wydawnictwo Dolnośląskie, Wrocław.

Cederstrom C., Spicer A., 2016. Pętla dobrego samopoczucia. Wydawnictwo Naukowe PWN, Warszawa.

Dukaj J., 2019. Po piśmie. Wydawnictwo Literackie, Kraków.

Frankl V., 2019. Człowiek w poszukiwaniu sensu. Wydawnictwo Czarna Owca, Warszawa.

Gazzaniga M., 2013. Kto tu rządzi - ja czy mój mózg. Smak Słowa, Sopot.

Hatalska N., 2021. Wiek paradoksów. Znak, Kraków.

Hickel J., 2021. Mniej znaczy lepiej. Karakter, Kraków.

Garbarski L., 2021. Kreatywność w biznesie. Czego możemy się nauczyć od artystów? Poltext, Warszawa.

Olejniczuk-Merta A., Noga A. (eds), 2020. Inwestycyjny wymiar konsumpcji. Poltext, Warszawa.

Kahneman D., 2012. Pułapki myślenia. O myśleniu szybkim i wolnym. Rebis, Poznań.

Kok J., van den Heuvel S., 2019. Leading in a VUCA World. Springer Nature, Cham.

Lee K., 2019. Inteligencja sztuczna, rewolucja prawdziwa. Media Rodzina, Poznań.

Mazzucato M., 2021. Wartość wszystkiego. Heterodox, Poznań.

Mintzberg H., 2019. Zarządzanie. Wydawnictwo Nieoczywiste, Warszawa.

Nestorowicz R., 2017. Asymetria wiedzy a aktywność informacyjna konsumentów na rynku produktów żywnościowych. Wydawnictwo UEP, Poznań.

Niebauer C., 2021. Neuronauka a buddyzm. Realne życie czy jego iluzja. Studio Astropsychologii, Białystok.

Ohme R., 2017. Emo sapiens, Harmonia emocji i rozumu. Bukowy Las, Wrocław.

Olejniczuk-Merta A., Noga A., 2020. Inwestycyjny wymiar konsumpcji. Istota, formy, znaczenie. Wydawnictwo Poltext, Warszawa.

Peretti J., 2019. Zakulisowe umowy, które zmieniły świat. Rebis, Poznań.

Pink D., 2014. Jak być dobrym sprzedawcą. Zaskakująca prawda o wywieraniu wpływu na ludzi. Emka, Warszawa.

Pink D., 2018. Kiedy. Naukowe techniki doskonalenia wyczucia czasu. Emka, Warszawa.

Rosling H., Rosling O., Ronnlund A., 2018. Factfulness. Media Rodzina, Poznań.

Shiller R.J., 2019. Narrative Economics. Princeton University Press.

Tetlock P.E., Gardner D., 2017. Superprognozowanie. Sztuka i nauka prognozowania. CeDeWu, Warszawa.

Thaler R., 2018. Zachowania niepoprawne. Tworzenie ekonomii behawioralnej. Media Rodzina, Poznań.

Bartosik-Purgat M. (ed.), 2017. Zachowania konsumentów. Wydawnictwo Naukowe PWN, Warszawa 2017. 


\title{
Anna Rogala, Ewa Jerzyk, Renata Nestorowicz
}

\section{Opportunities and threats related to the use of the IoT in the food market from the consumer's perspective*}

\begin{abstract}
Purpose: The aim of the paper is to identify the opportunities and threats resulting from the implementation of the IoT solutions in the food market. In the analysis we adopted the consumer's perspective, indicating both the convenience of using modern technologies and the threats related to the protection of the consumer's interests.

Design/methodology/approach: In the paper, we did a critical review of the literature, referring to empirical studies on the IoT, the IoF, and contemporary trends in purchasing behaviours.

Findings: The analysis of bibliographic references revealed both barriers to and stimulators of the development of the IoT in the food market. The most important things from the consumer's perspective are access to information, security, and support in better nutritional choices. Undoubtedly, the downsides of and barriers to the development of the IoT include concern about losing privacy and control, about being observed, and the fear of technology based on machine-to-machine (M2M) communication.

Originality: In the paper, we identified the opportunities of and barriers to the development of the IoT from the consumer's perspective and attempted to evaluate them.
\end{abstract}

Keywords: Internet of Things, IoT, Internet of Food, IoF, consumer behaviour, food markets

\footnotetext{
* The study was conducted within the research project Economics in the face of the New Economy financed within the Regional Initiative for Excellence programme of the Minister of Science and Higher Education of Poland, years 2019-2022, grant no. 004/RID/ 2018/19, financing 3,000,000 PLN.

AR - Poznań University of Economics and Business, Institute of Marketing, Department of Marketing Strategies • anna.rogala@ue.poznan.pl • (1) https://orcid.org/0000-0003-0580-1838

EJ - Poznań University of Economics and Business, Institute of Marketing, Department of Marketing Strategies • ewa.jerzyk@ue.poznan.pl • (D) https://orcid.org/0000-0001-8474-3570

RN - Poznań University of Economics and Business, Institute of Marketing, Department of Marketing Strategies • renata.nestorowicz@ue.poznan.pl• (1) https://orcid.org/0000-0002-7510-3747
} 


\section{Introduction}

Food production and consumption constitute an unsustainable system due to the generated threats to the environment and the depletion of renewable resources. A chance for achieving a sustainable food system is offered by the application of an Internet technology called the Internet of Things, which is a platform enabling the creation of new business models aimed at the protection of natural resources, combatting poverty, improving food safety and health, and reducing waste.

The sustainable food system should protect natural resources, be technically feasible, economically viable and socially acceptable (Holden et al., 2018). An important role in this system is played by consumers. According to Mintel, modern consumers need more information about food to improve their dietary habits and safety, and to receive support in sustainable behaviours. What is more, conscious and competent consumers shape the activity of companies, somehow putting pressure on the other participants of the supply chain, stimulating them to absorb innovations, including the IoT.

In this chapter, we deal with food consumers' behaviours associated with the pace of the development of technology, particularly the IoT. We will attempt to identify opportunities and threats related to this process from the perspective of end users.

\section{Consumer 4.0 in the food market}

Changes occurring in food consumption are a consequence of social and demographic transformations and the dynamic negative climate changes that resulted from, among other things, excessive, unsustainable consumption. These factors have translated into new trends in consumption and the evolution of consumer behaviour. Just like we are observing an industrial revolution, the effect of which is Industry 4.0, we are also witnesses to the appearance of consumer 4.0 on the demand side - the consumer whose main characteristic is the use of modern technologies. The similarities between consumers 3.0 and 4.0 include the customization of the offer they expect, its consistency with the values they believe in, and their willingness to belong to a group. What distinguishes consumer 4.0 is the expectation of more digitalised communication and building online relations. This contributes to the broadening of the spectrum of principles that are important to the modern consumer since, along with classical values, they also attach importance to digital ones, such as accessibility, freedom of choice, a user-friendly environment, and the right to privacy (Baciu, 2020).

The customization of the product offer and communication requires access to data which most modern consumers share on social media, registering on Internet fora, wanting to obtain a price reduction or access to information. 95\% of Poles declare that they find online security important, but the reality is quite different. Only $1 / 3$ of Internet users declare they read regulations, while $2 / 3$ of them are aware that they make their personal data available online (UKE, 2020). 
It should be remembered, however, that these are declarations rather than actual behaviours.

When discussing the values that modern food consumers are driven by, we should refer to the trends identified by Mintel (2021b): well-being, values and identity. Consumers are increasingly often showing a holistic attitude to nutrition, taking heed not only of the condition of their body, but also of their mental and emotional well-being. This results in increased interest in functional food, which makes people feel better, and in more attention paid to eating (mindfulness). The values to which the contemporary consumer often refers include, among others, quality, ecology, ethics and trust. A growing number of consumers are paying attention to the quality of the product, its origin, environmental impact (carbon emissions, carbon footprint), leaning toward sustainable consumption as they are aware of the influence of their consumption decisions not only on their health, but also on the environment and their quality of life and of the generations to come. Such consumers tend to choose vegetable rather than meat products; they purchase products from local suppliers, seasonal vegetables and fruit, meat, fish and eggs from ethical farms, where the well-being of animals is a priority. At the same time, they take action to reduce food wastage. Consumption behaviours may manifest the consumer's identity and values and satisfy their need to belong to a group.

Consumers 4.0 find values and belonging to a group important, but the values they advocate and the reference groups are not identical. This is why they are not a homogeneous segment in this respect, but they do have a common denominator: the increasing scope of the use of technologies. Technology can improve access to reliable information; it helps to customize diet and shopping and enables monitoring the efficiency of the diet followed. It can also be applied in the process of motivating people to introduce and maintain healthy eating habits and more sustainable consumption, as well as facilitating the establishment of communities focused around certain ideas or values.

Discussing global consumer trends, Mintel (2021a) identifies technology as one of seven core drivers of consumer behaviour. This is confirmed by data on the application of state-of-the-art technological solutions. Almost $60 \%$ of the global population are active Internet users, with 92.6 percent of them accessing the Net via mobile devices (Statista, September 2021). In Poland, in October 2021 the number of Internet users was 29.6 million. On average, 24.7 million people used this medium on a daily basis (interaktywnie.com, 2021a). The consumer segment accounts for around $60 \%$ of all Internet of Things (IoT) connected devices in 2020 (Statista, October 2021). Almost 1/4 of Poles admit that they use some kind of Internet of Things devices; usually, they are smart watches, fitness bands, and other accessories (13\%). Appliances (robot vacuums, fridges, ovens, coffee machines) are used by $3 \%$ of Poles, and virtual assistants by $2 \%$. As compared to the European Union average, these are significantly lower indicators (Statista, March 2021). However, the number of users of electronic devices in Poland grew very fast in the years 2015-2020, especially with regard to: video playback devices, connected to the TV (+551\%), physical activity monitors $(+519 \%)$, and smart 
watches (+311). Lower levels of uptake have been observed in the case of smart Internet-connected home devices that can be controlled by an application $(+82 \%)$ (Statista, 2021). What is more, over $1 / 4$ of Poles declare their willingness to use robots for household work, autonomous cars or self-checkout shops. Poles have a very positive attitude to modern technologies; $95 \%$ of Polish consumers find them to make their life easier and have a positive influence on everyday activity (Payback, 2021).

Mobile applications are also growing in popularity at a very fast pace. According to Kemp (2021), in 2020 the annual growth in the number of mobile apps downloads was $7 \%$, and the annual growth in the value of consumer spending on mobile apps: $20 \%$. At present, $69.4 \%$ of Internet users aged 16-64 use shopping apps, while $29.4 \%$ - health, fitness and nutrition apps (Kemp, 2021). In 2020, the share of internet users that use shopping apps each month in Poland in 2020 was $80.7 \%$, while health and fitness apps $-33.7 \%$ (Statista, 2021). The pandemic has sped up some changes in the market, increasing not only people's readiness to use applications and digital services, but also consumers' expectations regarding their reliability. According to a study by Cisco AppDynamics, people now use about $30 \%$ more applications than they did before the pandemic. Digital services have become an indispensable element of everyday pandemic life for $85 \%$ of the respondents, and $73 \%$ of them intend to continue the use of proven digital solutions even after the pandemic is over. What is interesting is that $3 / 4$ of consumers declare that their expectations concerning digital services grew from the beginning of 2020 , and $2 / 3$ of them believe that offering poor quality digital services is a sign of disrespect to customers (interaktywnie.com, 2021).

An interesting measure of the use of technologies for shopping is the Digital Influence Factor (DIF), which informs us what percentage of visits to traditional stores involve the use of digital devices at any stage of the path to purchase (before, during or after shopping). In 2021, its level in Poland was 61\%, while in $2019-60 \%$. Although the overall indicator did not increase a lot, the most significant change in this respect was observed with regard to food shopping: a growth of 4 percentage points, to the level of 54\% in 2021. Similarly, the Mobile Influence Factor (the measure of digital influence restricted to mobile phones) for food rose by 5 percentage points in the period under analysis, reaching $52 \%$. What is striking is that food was one of the few product categories for which the DIF increased over two years at all stages of the path to purchase, reaching - in 2021 - the level of $76 \%$ (at the pre-shopping phase), 39\% (during shopping) and $17 \%$ (at the post-shopping stage). It must be pointed out that it is not only the youngest consumers who avidly use technological solutions. Although the DIF fluctuates at around $2 / 3$ in the 18-24 age group, not exceeding $1 / 2$ among people over 55 years of age, it is in the oldest age group (65-70) that we observed the most significant growth of this indicator between 2019 and 2021 (Deloitte, 2021).

Consumers 4.0 are accustomed to the constant use of digital channels in their private and professional life; thus they expect access to information about products through these channels. It is obvious to them that this access should be as broad as possible, and that they should be able to compare price offers and 
check other users' opinions. They want information on the product or service to be delivered instantly, in a simple and convenient way. Information, just like the product itself, should be accessible in accordance with the principle of anything, anytime, anywhere. Consumers expect to be able to get involved and have an experience before, during and after the purchase. This is where artificial intelligence can be used. Owing to an in-depth analysis, not only will it perform a segmentation of the buyers, but it will also adjust the content of messages and select the right channels to convey them, in line with purchasers' preferences. Modern consumers are generally (62\%) open to companies using artificial intelligence for improving customer service (Deloitte, 2019a).

Although consumer 4.0 is considered to be a new phenomenon, more and more references are already being made to consumer 5.0, who will additionally expect all five senses to be influenced, even if marketing communication is done exclusively online. This is yet another technological challenge. However, given the fact that technology is the fastest changing determinant of consumption, and that the work on the Internet of senses - i.e., bringing sensory experiences to the digital world - is in progress (Hatalska, 2021), it will not be long before consumer 4.0 changes smoothly into consumer 5.0 , and then expectations regarding the implementation of the IoT or the IoF will be even higher.

\section{The infrastructure of the Internet of Things}

The Internet of things (IoT), referred to as a digital revolution, is a network of dispersed, wired or wireless autonomous devices, which can obtain, share and process data, or interact with the external environment through the application of telecommunication networks and Internet technologies (IoT w polskiej gospodarce, 2020). Within the IoT, interoperable and controllable devices are used and they can communicate without human intervention. Such objects may include sensors, computers, tablets, Internet cameras and smartphones. The IoT technology extends the previous vision of the usefulness of the Internet, which was associated with a computer linked to the network, to include every object that can receive and send digital information (machine2machine; M2M). If we measure the development rate of the IoT with the number of M2M interactions, in 2017 almost a billion connections were identified, and it is estimated that there will be four billion of them in 2022 (Bouzembrak et al., 2019). The IoT is a specific ecosystem in which devices interact and they are able to optimize various business processes in real time.

The slow absorption of IoT solutions into the economy has influenced individual industries to varying degrees and at different paces. We observe a growing demand for modern, miniaturised and smart devices and components with low power consumption. One must be aware, however, that devices are only a component of the IoT process and they have no value in themselves. Only the creation of an ecosystem in which integrated devices will communicate with each other independently will give them usability. In turn, to create this ecosystem, one has 
to possess knowledge of the processes which should be optimised and the competence and skills needed to connect smart devices. Another important issue in the discussion on the implementation of IoT solutions is the social aspect of changes triggered by technological development.

The analysis of individual markets and industries shows the enormous potential for the application of the IoT, with data indicating the biggest volume of investment in the consumer market. It is forecast that IoT spending in the consumer sector will more than double in the years 2017-2022 (IoT w polskiej gospodarce, 2020). From the consumer's perspective, we observe changes in transportation, especially in cities, smart parking systems, solutions dedicated to omnichannel, smart homes, or monitoring health parameters (bands for senior citizens). The COVID-19 pandemic has sped up the introduction of new solutions in healthcare, including those related to the monitoring and remote supervision of patients.

The application of the IoT in food supply chains is considered to be one of the most promising new areas with broad implementations in food production, processing, storage, distribution and consumption. New, IoT-based technologies are expected to ensure safer, more efficient and more sustainable supply chains in the near future (Bouzembrak et al., 2019).

Food is an important condition of well-being. Not only does it provide nutrients, but it also influences cultural identity and social relations. Food and eating habits have a direct connection with the frequency of the occurrence of illnesses such as obesity, diabetes and other diet-related health problems. It is predicted that Internet technologies, cloud processing and big data can create a system which will contribute to the improvement of the quality of life of the current and future generations. On the consumer's level, the IoF has a crucial role to play as it promotes important and socially desirable goals and behaviours (combatting poverty, health improvement, care of natural resources, reduction of food wastage), but it also generates costs, leads to consumers' losing their privacy, and causes their uncertainty regarding things and technology.

The term Internet of Food (IoF) appeared in the scientific literature as the idea that each food should have its own IP identity. This gave rise to discussion on the extent to which this technology may change our consumption patterns and whether we will have to control our dietary behaviours and everything we eat: the size of portions, ingredients, calorie content, the way our food is delivered, etc. The IoF refers to the whole food sector and is based on sensors measuring different parameters in the food chain, dedicated to monitoring soil, crops, breeding, logistics and consumption. Due to the data gathered from the whole system, we can integrate information concerning production, processing, logistics, retail sale, consumption, nutrition and health. From the consumer's point of view, however, it is other functionalities that may be of interest. These are, for example, applications which diagnose eating habits (e.g., My Food Phone monitors the consumer's diet by enabling the user to send photographs of food items and receive feedback from a dietician), count calories and evaluate the quality of meals, and calculate the size of purchased and consumed food (monitoring receipts) (Mankoff et al., 2002). Apart from mobile applications dedicated to consumers, there are trial 
tests of solutions consisting in introducing sensors in the space in which meals are prepared and consumed. Smart kitchens can improve cooking at home, increasing cooks' awareness regarding the calorie count in dishes. The IoT in the kitchen involves placing sensors for monitoring calories in food, installing scales under the worktop, and using cameras for product recognition. Cooks are provided with information on the calorie content of the dishes they prepare in real time. The research conducted among users confirms that - thanks to this tool - family cooks find it easier to maintain suitable levels of calories. The study by Chi et al. (2008) revealed that in the case of consumers with no nutritional knowledge, the applied IoT system helped to reduce calories in meals served by $24 \%$ on average, as compared to the test cooking phase (without the IoT). What is more, it was observed that cooks manifested different levels of attention to the calorie display. The analysis showed that they spent less than a second studying low-calorie ingredients (such as garlic $-2 \mathrm{kcal}$ ), but they needed more time for high-calorie ones (such as spaghetti and oil). The longer time needed to absorb information about calorie content probably stemmed from the necessity of adjusting the subsequent ingredients of the dish prepared.

Another solution within the framework of the IoT is the application of extended reality during cooking to support cooks in the process of meal preparation (seeking products, diagnosing their temperature, monitoring the length of heat treatment, etc.). In this case, it is not only about the safety and efficiency of cooking processes, but also about socialization - sharing experience with other users (Siio et al., 2007).

Digital technologies, such as the IoF, improve consumers' shopping experiences, making them more customised, convenient and engaging (Gregory, 2015). The IoT can help the consumer to locate the food item quickly, and display its details and nutritional value, thanks to sensors placed on products, and show the updated prices and promotional offers. An important determinant of purchasing decisions is the perception and evaluation of food safety. According to the research, this is determined by access to information (Zhang et al., 2019). The demand for information has been traditionally satisfied by product packaging, which, at the key shopping moment, helped to make better purchasing decisions. Nutritional and health declarations, expiration dates, and tables of nutrients presented on food product packaging provide knowledge, and educate and support customers in their food choices. Unfortunately, they are also a tool in the competitive battle among manufacturers and sellers, who use packaging as a sales instrument to persuade customers to buy highly processed foods. Health claims on such products provide information about added values, but oversimplification and the hedonistic form of communication distort the message, while their promotional character encourages people to buy a given item. Such messages placed on processed products help no one but those who want to sell them (Williams, 2005). The increased amount of information and its complexity on packaging discourage consumers from using it consciously in the purchasing process. Moreover, it leads to the erosion of trust in this communication channel. Consumers are not able to verify whether information on the packaging is true; they generally 
have difficulty in interpreting it, which makes them seek other sources of information, and the IoF comes in handy here.

\section{Opportunities and threats related to the application of the loT}

Solutions based on modern technologies are usually popular among consumers, especially those belonging to the group of innovators, who enthusiastically adopt all kinds of market novelties and spread positive opinions via word of mouth. It must be remembered, however, that apart from the benefits, these solutions may also entail some dangers. This is why the study of the use of the IoT should concern not only its usefulness for the consumer, but also its security. Porter and Heppelmann (2014) indicate that the main challenges of the implementation of the IoT solutions include: standardization, customization, software update and security. From the point of view of the analysis of opportunities and threats to the consumer's interest, we should focus on two of them, namely customization and security.

Devices which are interconnected within the IoT infrastructure collect a lot of complex and complementary data concerning consumers and their behaviours. Owing to this, it is possible to provide highly-customised products or services to an individual buyer (Taylor et al., 2020). For example, on the basis of previous purchases made via a mobile app, the current contents of the smart fridge and the health parameters taken from the smart band, a dedicated, customised shopping list which will take into consideration consumers' nutritional needs can be created and then the selected products can be delivered at the most convenient time for them, estimated based on the timetable from their calendar and the location data from the smartphone. Such solutions significantly reduce the time needed for shopping in the traditional formula - from the analysis of food articles we have in the fridge, through going to the shop, to bringing the products we bought home. The decision-making process is not only considerably shortened, but it is also a lot simpler. The consumer is thus, in a way, replaced by IoT solutions, which, based on the analysis of data obtained from different sources, adapt products and services offered to their previous behaviours and needs, at the same time providing tangible benefits (Borgia, 2014).

Thanks to data gathered within the framework of the IoT, it is possible to carry out the communication activity in a way that will give consumers access to information that is necessary in a given situation and decision context. Devices monitor their behaviours in real time and allow the content to be adjusted to a specific stage in the decision-making process or a point on the path to purchase (Spilotro, 2016). Thus, consumers receive the customised answer to their questions in real time and through the channels that are the most convenient to them. At the same time, the content that is unwanted and uninteresting from their perspective is eliminated (Marek and Woźniczka, 2018). Communication is thus highly- customised and highly-contextual (Chudy, 2019). Hence, communication activities conducted within the framework of the IoT infrastructure can support 
consumers in making specific food choices and, more importantly, in changing dietary patterns into healthier or more sustainable ones.

The analysis and use of data obtained by smart devices makes it possible to design the architecture of choice which contributes to consumers' food and subjective well-being, and at the same time encourages them to follow sustainable food consumption (Rogala et al., 2022). To this end, mobile apps can be used, as they reward consumers for proper behaviour - nutritional and shopping in this case in real time (Tariq et al., 2020), which makes them happier and encourages them to persist in the decision to change their eating habits into healthier and more sustainable ones. Thus, not only can the IoT infrastructure support us in our daily activity related to food shopping and organizing meals, but it can also help us in going through the difficult process of changing the consumption pattern.

Despite a number of opportunities to make the consumer's life easier and more pleasant, the application of the IoT is not free of threats to their interests. The most sensitive areas include big data tracking, ensuring the privacy and security of that data, and the ethics of collecting unnecessary data (Spilotro, 2016). It should be pointed out that the same data that is used for increasing consumers' satisfaction, through the personalization and customization of the products, services and communication activities offered to them, may be used against their interest, e.g., jeopardizing their wealth, health or, in extreme cases, even, life. Therefore, uncontrolled supervision, hackers' attacks or taking control over devices pose a real threat (Rot, 2017). Unfortunately, neither security nor privacy features are perceived as ones that the vendor or the consumer want to pay extra for. A number of cheap IoT devices have limited cryptographic capability and are therefore vulnerable to cyberattacks (Maddyness.com, 2021). At the same time, research shows that without any clear signs that an IoT device has been infected, consumers find it difficult to detect this fact. What is more, they are not aware of the threats this may entail for the whole network of interconnected devices (McDermott et al., 2019). Meanwhile, devices that are an indispensable element of the consumer's daily life, often have security holes in the system, thus becoming the target of cyberattacks thanks to which hackers gain access to the physical world of the consumer (Shin and Jin Park, 2017). Moreover, they have a finite lifespan and in the case of recycling, trading, selling, replacing or donating them, decommissioning is needed in order to protect the user's sensitive private data (Khan et al., 2019). Therefore, issues related to ensuring security are particularly important at the stage of designing new solutions (Yousuf and Mir, 2019).

Consumer privacy is considered to be one of the biggest ethical challenges that societies have to face in the information age. On the other hand, the social acceptance of technology, leading to the common use of smart devices, makes this challenge even bigger (Foltz and Foltz, 2020). IoT devices collect data which enable the identification of customers in order to understand their behaviours and delivering them what they most need at a given moment. This data covers users' location and movements, purchasing preferences and health conditions, among other things (Lee and Lee, 2015). Consumer awareness of how this data is gathered and how and by whom it can be used is relatively low (Zheng et 
al., 2018). Hence, most consumers unconsciously give up their privacy in return for convenience and personalization (Bannan, 2016). Data collected within the framework of the IoT infrastructure is often available to third parties or companies, usually without the consumer's consent or with unintended consent, which is given when accepting the conditions of use of a device, but without studying them thoroughly. This increases the risk of data leaks and data privacy breaches (Kahn et al., 2019). Therefore, we need initiatives which will guarantee the protection of consumer privacy, while at the same time not limiting the possibility of taking benefits from the IoT (Marek and Woźniczka, 2018; Dutton, 2014).

Other threats include varying quality in the Internet infrastructure of the consumer environment, which may hamper the use of the IoT and the exclusion of some consumer groups from the possibility of using modern technology. The quality of connections and the demand for power of mobile devices and data processing systems in real time may exclude some consumers from being the IoT users, which leads to lower benefits. IoT technology should be friendly to all users, so all deficiencies in this respect will impede the diffusion of innovations and scalability. Consumers may also be worried about the lack of regulations with regard to obtaining, processing and sharing data, and feel concerned about the predictions of the further development of this technology, which involves placing sensors on the human body (implanting sensors that measure, e.g., the level of sugar or the demand for calories resulting from current effort). For many potential users of the IoT, this could be a barrier which will be difficult to overcome.

Modern consumers are also aware of the value of information on their behaviours and this is why it is predicted that they may expect to be rewarded for sharing it. The appearance of such expectations will affect the pace of the introduction of new innovations in the field of the IoT. On the basis of Rogers' diffusion of innovations theory, it can be said that most consumers are imitators. They prefer observing the introduced innovations and the new uses of products and services based on artificial intelligence. This demand barrier has an effect on the pace of the introduction of IoT solutions addressed to end users.

\section{Conclusions}

It is estimated that the Internet of Things (IoT) will play a significant role in offering tangible benefits to subjects who are part of the food supply chain, and will make manufacturing, processing and transportation processes more efficient and ecological. However, despite the enormous potential of the IoT, its implementation in food supply chains is still in the initial phase because of the degree of complexity, costs and uncertain benefits. The broadest scope of uses is now observed in IoT retailing, with regard to controlling the quality of grocery products, planning the waste management of the products whose shelf life of has expired, or monitoring temperature in a shop, freezers and other equipment, thereby contributing to a reduction in power consumption (Kamble et al., 2019). 
Information gathered within the framework of the IoT system at the different stages of the supply chain is also important in the processes of food purchase and consumption. From the consumer's perspective, the use of the IoT infrastructure provides numerous opportunities to make our life easier and more pleasant, but it also entails some threats to our security and privacy. This equivocal evaluation of the IoT potential is confirmed by research conducted among young consumers, who found the loss of privacy to be the biggest disadvantage of using IoT devices, while at the same time appreciating their convenience and ability to generate savings (Mącik, 2016). A large number of people do not want to share personal sensitive information, which makes them reluctant to begin using IoT devices (Khan et al., 2019).

The critics of the IoT point out that it contributes to undermining such values as privacy, equality, trust and individual choice (Dutton, 2014). In combination with consumers' fears, it clearly shows that legislative regulations are necessary to respond to ethical, legal and other social risks concerning the use of the IoT. At the same time, it is important that efficient security architecture be established to increase its users' security.

\section{References}

Baciu L., 2020. Customers 4.0: Who They Are? What They Want? Why Companies Should Reinvent for Them? (https://www.lumeer.io/customers-4-0-who-they-are/; access: 24.11.2021).

Bannan Ch., 2016. The IOT threat to the privacy (https://techcrunch.com/2016/08/14/ the-iot-threat-to-privacy; access: 24.11.2021).

Bartuzi Z., 2018. Zmiana oblicza alergii pokarmowej u dorosłych. Alergia 3: 24-2 (https:// journals.indexcopernicus.com/api/file/viewByFileId/479973.pdf; access: 24.11.2021).

Borgia E., 2014. The Internet of Things Vision: Key Features, Applications and Open Issues. Computer Communications 54: 1-31 (https://doi.org/10.1016/j.comcom.2014.09.008).

Bouzembrak Y., Klüche M., Gavai A.K., Marvin H.J., 2019. Internet of Things in food safety: Literature review and a bibliometric analysis. Trends in Food Science and Technology 94: 54-64 (https://doi.org/10.1007/978-3-540-68504-3_11).

Chi P.Y., Chen J.H., Chu H.H., Lo J.L., 2008. Enabling Calorie-Aware Cooking in a Smart Kitchen. In: Oinas-Kukkonen H., Hasle P., Harjumaa M., Segerståhl K., Øhrstrøm P. (eds), Persuasive Technology. Lecture Notes in Computer Science 5033. Springer, Berlin, Heidelberg.

Deloitte, 2019a. Jak wykorzystać sztuczną inteligencję w marketingu: trzy sposoby na podniesienie poziomu doświadczeń konsumenckich. Digital Marketing Newsletter 7 (https://www2.deloitte.com/pl/pl/pages/deloitte-digital/digital-marketing-newsletter-deloitte/digital-marketing-sierpien-2019/jak-wykorzystac-sztuczna-inteligencjew-marketingu-trzy-sposoby-na-podniesienie-poziomu-doswiadczen-konsumenckich. html; access: 24.11.2021).

Deloitte, 2019b. Koniec ery dwóch światów. Wpływ narzędzi cyfrowych na zakupy Polaków (https://www2.deloitte.com/pl/pl/pages/consumer-business/articles/koniec-ery-dwoch-swiatow-raport-digital-divide.html; access: 24.11.2021). 
Dutton W.H., 2014. Putting things to work: social and policy challenges for the Internet of things 16(3): 1-21 (https://doi.org/10.1108/info-09-2013-0047).

Foltz C.B., Foltz L., 2020. Mobile users' information privacy concerns instrument and IoT. Information and Computer Security 28(3): 359-371 (https://doi.org/10.1108/ICS-072019-0090).

Gregory J., 2015. The Internet of Things: revolutionizing the retail industry. Accenture Strategy, 1-8.

Hatalska N., 2021. Wiek paradoksów. Czy technologia nas ocali? Wydawnictwo Znak, Kraków.

Holden N.M., White E.P., Lange M.C, 2018. Review of the sustainability of food systems and transition using the Internet of Food. Npj Sci Food 2(18) (https://doi.org/10.1038/ s41538-018-0027-3).

interaktywnie.com, 2021a. Polski internet w październiku 2021 roku. Oto najpopularniejsze portale i aplikacje (https://interaktywnie.com/biznes/newsy/biznes/polskiinternet-w-pazdzierniku-2021-roku-oto-najpopularniejsze-portale-i-aplikacje-261650; access: 24.11.2021).

interaktywnie.com, 2021b. Aplikacje mobilne w ocenie konsumentów. Za problemy automatycznie obwiniamy markę (https://interaktywnie.com/biznes/newsy/new-business/aplikacje-mobilne-w-ocenie-konsumentow-za-problemy-automatycznieobwiniamy-marke-261338; access: 24.11.2021).

Internet rzeczy w polskiej gospodarce. Raport Ministerstwa Cyfryzacji, 2019. (https:// www.gov.pl/web/cyfryzacja/polska-przyszlosci-to-polska-z-internetem-rzeczy; access: 24.11.2021).

Kamble S.S., Gunasekaran A., Parekh H., Joshi S., 2019. Modeling the internet of things adoption barriers in food retail supply chains. Journal of Retailing and Consumer Services 48: 154-168 (https://doi.org/10.1016/j.jretconser.2019.02.020).

Kemp S., 2021. Digital 2021. Global Overview Report, We are social, Hootsuite (https:// datareportal.com/reports/digital-2021-global-overview-report; access: 24.11.2021).

Khan W.Z., Aalsalem M.Y., Khan M.K., 2019. Communal Acts of IoT Consumers: A Potential Threat to Security and Privacy. IEEE Transactions on Consumer Electronics 65(1): 64-72 (https://doi.org/10.1109/TCE.2018.2880338).

Khan W.Z., Alsalem M.Y., Khan M.K., Arshad Q., 2019. Antecedents affecting consumer trust towards adopting Internet of Things enabled products. IEEE Transactions on Consumer Electronics 8(2).

Lee I., Lee K., 2015. The Internet of Things (IoT): Applications. Investments, and Challenges for Enterprises. Business Horizons 58(4): 431-440.

Maddyness, 2021. IoT: Internet of Threats? (https://www.maddyness.com/uk/2021/09/15/ iot-an-internet-of-threats/; access: 24.11.2021).

Mankoff J., Hsieh G., Hung H.C., Lee S., Nitao E., 2002. Using Low-Cost Sensing to Support Nutritional Awareness. In: Borriello G., Holmquist L.E. (eds), UbiComp 2002: Ubiquitous Computing. UbiComp 2002. Lecture Notes in Computer Science 2498. Springer, Berlin, Heidelberg (https://doi.org/10.1007/3-540-45809-3_29).

Marek L., Woźniczka J., 2018. The Internet of Things as a customer experience tool. Jagiellonian Journal of Management 3(3): 163-176 (https://doi.org/10.4467/2450114XJ JM.17.011.9562).

Mącik R., 2016. „Internet rzeczy” - postrzegane przez młodych konsumentów korzyści i zagrożenia - wyniki badań wstępnych. Przedsiębiorczość i Zarządzanie 17(4): 11-27.

McDermott C., Isaacs J., Petrovski A., 2019. Evaluating Awareness and Perception of Botnet Activity within Consumer Internet-of-Things (IoT) Networks. Informatics 6(1): 8. (https://doi.org/10.3390/informatics6010008). 
Mintel, 2021a. Global Consumer Trends 2022. What consumers want and why - now, next and in the future (https://www.mintel.com/global-consumer-trends; access: 24.11.2021).

Mintel, 2021b. Trendy na globalnym rynku żywności i napojów (https://polska.mintel. com/trendy-na-globalnym-rynku-zywnosci-i-napojow; access: 24.11.2021).

Payback, 2021. Polacy i nowoczesne technologie. Dobrodziejstwo czy udręka? https:// www.egospodarka.pl/169076,Polacy-i-nowoczesne-technologie-Dobrodziejstwo-czyudreka,1,39,1.html; access: 24.11.2021).

Porter M., Heppelmann J., 2014. How smart, connected products are transforming competition. Harvard Business Review 92(11): 64-88 (https://hbr.org/2014/11/ how-smart-connected-products-are-transforming-competition; access: 24.11.2021).

Rogala A., Jerzyk E., Nestorowicz R., 2022. Possibilities of Using the Internet of Things in Marketing Communication to Shape Sustainable Food Consumption Attitudes. Working paper submitted for Marketing Trends Conference Rome 2022. To be published in 2022.

Rot A., 2017. Bezpieczeństwo jako najważniejsze wyzwanie koncepcji Internetu rzeczy. Przedsiębiorczość i Zarządzanie 18(4), 2: 285-296.

Shin D.-H., Jin Park Y., 2017. Understanding the Internet of Things ecosystem: multi-level analysis of users, society, and ecology. Digital Policy, Regulation and Governance 19(1): pp. 77-100 (https://doi.org/10.1108/DPRG-07-2016-0035).

Siio I., Hamada R., Mima N., 2007. Kuchnia przyszłości i zastosowania. [in:] Jacko J.A. (ed.), Interakcja człowiek-komputer. Platformy i techniki interakcji. HCI 2007. Notatki z wykładów z informatyki 4551. Springer, Berlin, Heidelberg (https://doi. org/10.1007/978-3-540-73107-8_104).

Spilotro Ch.E., 2016. Connecting the Dots: How IoT is Going to Revolutionize the Digital Marketing Landscape for Millennials. Undergraduate Honors Theses 25 (https://digital.sandiego.edu/honors_theses/25; access: 24.11.2021).

Statista, 2021. Mobile internet usage in Poland (https://www.statista.com/study/66669/ mobile-internet-usage-in-poland/; access: 24.11.2021).

Statista, March 2021. Share of individuals using Internet of Things devices in Poland and the European Union in 2020, by type of device (https://www.statista.com/ statistics/1219609/poland-individuals-using-internet-of-things-devices/; $\quad$ access: 24.11.2021).

Statista, October 2021. Number of Internet of Things (IoT) connected devices worldwide from 2019 to 2030 (https://www.statista.com/statistics/1183457/iot-connected-devices-worldwide/; access: 24.11.2021).

Statista, September 2021. Global digital population as of January 2021 (https://www.statista.com/statistics/617136/digital-population-worldwide/; access: 24.11.2021).

Tariq B., Taimoor S., Najam H., Law R., Hassan W., Han, H., 2020. Generating Marketing Outcomes through Internet of Things (IoT) Technologies. Sustainability 12(22): 9670 (https://doi.org/10.3390/su12229670; access: 24.11.2021).

Taylor M., Reilly D., Wren Ch., 2020. Internet of things support for marketing activities. Journal of Strategic Marketing 28(2): 149-160 (https://doi.org/10.1080/096525 4X.2018.1493523).

UKE, 2020. Badanie opinii publicznej w zakresie funkcjonowania rynku usług telekomunikacyjnych oraz preferencji konsumentów. Raport z badania klientów indywidualnych.

Williams P., 2005. Consumer Understanding and Use of Health Claims for Foods. Nutrition Reviews 63(7): 256-264 (https://doi.org/10.1111/j.1753-4887.2005.tb00382.x). 
Yousuf O., Mir R.N., 2019. A survey on the Internet of Things security: State-of-art, architecture, issues and countermeasures. Information and Computer Security 27(2): 292-323 (https://doi.org/10.1108/ICS-07-2018-0084).

Zhang J., Cai Z., Cheng M., Zhang H., Zhang H., Zhu Z., 2019. Association of Internet Use with Attitudes Toward Food Safety in China: A Cross-Sectional Study. International journal of environmental research and public health 16(21): 4162 (https://doi. org/10.3390/ijerph16214162).

Zheng S., Apthorpe N., Chetty M., Feamster N., 2018. User Perceptions of Smart Home IoT Privacy. Proceedings of the ACM on Human-Computer Interaction 2(CSCW), 200 (https://doi.org/10.1145/3274469). 


\title{
Possibilities of the application of VR technology for shaping the awareness and pro-ecological attitudes of food consumers (a case study of the Pollinator Park application)
}

\begin{abstract}
Purpose: The aim of the article is to analyse the possibilities of using virtual reality (henceforth, VR) technology to shape the awareness and pro-ecological attitudes of food consumers.

Design / methodology / approach: The basis for the analysis was the study of literature on marketing communication, social communication, VR and ecology, as well as the VR application "Pollinator Park", developed in 2021 at the request of the European Commission, as part of activities aimed at increasing society's environmental awareness.

Findings: The analysis of VR technology, carried out using the example of the VR "Pollinator Park" experience, indicates that VR meets the assumptions of experience marketing in practice and can potentially be an effective tool for shaping attitudes and behaviours that affect the food market and the natural environment. Nevertheless, the innovative nature of the tool entails that a mass audience cannot currently be reached with the message. Practical implications: In terms of practical application, the work is related to indicating the conditions, benefits and limitations of using VR technology in activities aimed at shaping the awareness and pro-ecological attitudes of food consumers.

Originality and value: The considerations in the article concern transdisciplinary issues: marketing communication, social communication, VR and ecology. While there is a large body of literature on marketing communication, social communication and ecology, issues related to VR technology have attracted the interest of only a small group of researchers. Given the growing popularity of VR technology, knowledge of the possibility of using it to shape the awareness and pro-ecological attitudes of food consumers may turn out to be valuable both for public and private institutions.
\end{abstract}

Keywords: virtual reality, food market, experience economy, experience marketing.

MG - Poznan University of Economics and Business, Institute of Marketing, Department of Marketing Strategies • marcin.gurtatowski@gmail.com • (D) https://orcid.org/0000-0001-7010-572X 


\section{Introduction}

Throughout the world today, we are witnessing the mass extinction of insects, which are involved in pollinating a number of plant species. A decline in the population of honeybees, the most important species of pollinators, is causing enormous economic losses in food production and may lead to a decrease in plant biodiversity in a few decades to come. This phenomenon is a consequence of environmental degradation and industrial food processing. To counteract the above trend, changes in the methods of food production and in the area of consumption behaviours must be introduced - with more emphasis on solutions taking into consideration environmental protection. Against the background of these challenges, we will undertake an analysis of virtual reality technology in terms of its potential for shaping awareness and pro-ecological attitudes. Our paper is based on a study of the literature on the subject and the VR application "Pollinator Park", developed in 2021 at the request of the European Commission, as part of activities aimed at increasing society's environmental awareness.

\section{Causes of bee extinctions and the implications for the food market and biodiversity}

Since the 1980s, a steady decline in pollinator populations has been observed in a number of ecosystems all over the world (Biesmeijer et al., 2006). This phenomenon is an element of an ongoing extinction of species, referred to as the "sixth extinction" (Kolbert, 2014). In 2006, on the territory of the United States, the first sudden drop in the population of honeybee colonies became apparent. It was named colony collapse disorder (CCD) (Cummings, 2007). At present, we are also observing this phenomenon in a lot of European countries (Schulp et al., 2013). According to a Greenpeace report, over the last few years the median mortality rate of bees in the autumn and winter season in Europe was around $20 \%$ (ranging from $1.8 \%$ to 53\%, depending on the country) (Tirado et al., 2013). Some bee species are in danger of extinction. This concerns, for example, almost a half of 470 solitary bee species living on the territory of Poland (Greenpeace, 2015, p. 7).

The underlying cause of the mass extinction of honeybees is not known. However, there are some hypotheses concerning the possible sources of this phenomenon. Researchers believe that it is caused by a number of factors that act synergically (Bekić et al., 2014). The study conducted by Osborne (2012) showed that some pesticides used for the protection of plants against harmful or undesirable organisms weaken the immune system of bees, making them vulnerable to viruses and parasites.

The demand for pollinators is outpacing their supply (Tirado, Simon and Johnston, 2013, p. 4), which contributed to the creation of the market of renting bees for crop pollination. Barrionuevo (2007) points out that migratory beekeeping has a negative impact on the health of insects as it involves hiring bees, which 
necessitates transporting them to distant locations. Moving bees to farming fields where there is a shortage of local pollinators leads to the spreading of illnesses, viruses and parasites.

The repertoire of harmful factors is a great deal larger. Gliński and Kostro (2007, pp. 652-653) indicate that bees used in monocultural crops are deprived of access to diverse plants, which may lead to their malnutrition. The research carried out by Leonard and team (2019) reveals that air pollution impairs honeybees' sense of smell and weakens their ability to learn and memorize, which, in turn, makes it more difficult for them to find food. Salvatore et al. (2021) stress the potentially negative influence of toxins produced by genetically modified plants on the immune system of bees.

Through moving pollen, insect pollinators play a part in the reproduction of many different plant species. The phenomenon of mass bee extinction has enormous consequences for the global ecosystem. Tirado, Simon and Johnston (2013, p. 3) point out that it is not possible to estimate the economic value of natural biodiversity. Researchers emphasize that pollinators participate in the reproduction process of not only arable crops, but also of almost $90 \%$ of wild plants, thus ensuring habitats for other ecosystems.

The yield of $75 \%$ of the main crops worldwide depends on insect pollinators (Klein et al., 2007). It is honeybees and wild bees that make the biggest contribution to this process (Breeze et al., 2011). Out of 100 species of arable plants, representing $90 \%$ of food in the world, as many as 71 are pollinated by bees (Gallai and Vaissière, 2009).

The economic analysis conducted by Kevan and Philips (2001) showed that the deficit of pollinators, which caused a drop in agricultural yields, could lead to price increases in the food market and reduced availability of food products. According to Greenpeace (2015, p. 7), the global economic value of insect pollinators, estimated on the basis of the value of yields dependent on the pollination process, is 265 billion dollars per year. Tirado, Simon and Johnston (2013, p. 3) stress the fact that if insect pollinators did not mediate in the process of pollination, another, more expensive pollination method would have to be used for about $1 / 3$ of food crops. Otherwise, there would be a drop in yields in the case of approximately $75 \%$ of all arable plants. The deficit of pollinators would have a very negative impact on the availability of fruit and vegetables, which are indispensable to the human diet, and of some forage plants used in the process of meat and dairy production. Bees play a key role in the production of, among other things, apples, cherries, pears, strawberries, tomatoes, cucumbers, melons, apricots, citrus, peaches, pumpkin, numerous herbs, buckwheat and rapeseed (Greenpeace 2015, p. 7).

According to Majewski (2016, p. 176), the value of honey made in Poland ranged from about 250 million zloty to 500 million zloty yearly from 2005 to 2014. The value of yields generated owing to the pollination of the main arable plants was from 10 to 15 times bigger than the value of honey. In turn, the total economic value of bees ranged from 2.5 billion zloty in 2005 to 6.1 billion zloty in 2013. Greenpeace (2015, p. 3) estimated that if it the pollination of crops was 
impossible in Poland, their value in 2015 would have been lower by 4.1 billion zloty. The economic value of the pollination of apples alone in Poland amounts to 1.5 billion zloty yearly; of rapeseed - about 1 billion zloty per year, while of three other crops: over 0.24 billion zloty annually (Greenpeace, 2015, p. 17).

\section{Feedback}

It can be seen that the relationship between food production and the condition of pollinators has become a form of feedback today. Industrial agriculture, based on monocultural crops, genetically modified plants and the use of plant protection chemicals, negatively affects the health and life of insect pollinators. They, in turn, play a crucial role in the production of fruit and vegetables.

This paradox can be solved owing to the concept of the bioeconomy, which proposes that economic activity should be based on the rational use of natural resources and should serve the good of people and their environment (Kukuła, 2015). Rokicki (2015) emphasizes that raw materials should be sourced from land, water, air and living organisms in a way which would not restrict access to resources for future generations.

To put the ideas of the sustainable bioeconomy into practice, it is necessary that both the manufacturers and consumers of food improve their ecological awareness and undertake pro-ecological activities. The purchasing decisions of the latter have a direct influence on the food market.

The social marketing paradigm assumes that the same marketing principles and techniques apply to the promotion of products and services in the area of business and to social ideas and socially desirable behaviours (Grębowski, 1997). Hence, organizations belonging to the public and social sector can take advantage of scientific achievements in the marketing field and use the current marketing concepts and tools when running social campaigns.

\section{Paradigm change}

According to neoclassical economics, consumers make their choices on the basis of the principle of maximizing benefits (Lawson, 2013). By adopting the rational choice theory as the only axiom (Scott, 2000, pp. 126-127), we ignore the psychological and emotional determinants of decision-making. Neither does neoclassical economics take into consideration nonmaterial and difficult to estimate ecological costs. Goodland and Ledec (1987) suggested that overlooking environmental costs in the cost and benefit analysis may lead to a preference for economic projects with short-term benefits and long-term costs, which often brings highly negative consequences to the natural environment.

On the basis of research, Kahneman and Tversky (1979) formulated the prospect theory, which stands in opposition to the theory of expected utility dominant in the main current of economics. The prospect theory explains the 
influence of psychological cognitive distortions on economic decision-making in the conditions of risk. The researchers proved that in the case of choosing between two alternatives, one prefers those which are perceived as likely to bring a potential gain to those which are presented in terms of potential losses.

The rejection of the axiom of consumers' full economic rationality led to the establishment of a new, interdisciplinary science on the border of economics and psychology - behavioural economics, which studies and discusses the influence and consequences of economic, psychological, emotional and social factors on the process of making economic decisions (Thaler, 1980).

\section{The experience economy and marketing}

By broadening the perspective of economical sciences, we were able to discern important changes occurring within the sphere of social and economic life. Ritzer (2001, p. 313) pointed out that consumption is currently less related to the purchase of goods and services and is more about taking pleasure from the very act of consumption. Modern societies are thus becoming experience societies. Wikström (2008) indicated that a change consisting in consumers' preferring experiences and giving up the consumption of material goods, stems from the growth of people's individualism and their focus on self-actualization. The two main forces responsible for changing consumption patterns are, first, the increase of the economic wealth of societies and mass consumption satiation and, second, individualism and liberal values, manifested in the attitude of expecting more possible choices.

Lenderman (2006) argued that this change has led to the appearance of a new kind of consumers - prosumers. They are less influenced by classical marketing tools. They consider a positive brand image and high quality products as taken for granted. They are set on having experiences which they believe differentiate products and services better than more tangible benefits. Pine II and Gilmore (1998) even proclaimed the birth of a new type of economy, referred to as the experience economy, the driving force of which is the wealth creation and technological development of societies, allowing businesses to provide consumers with diverse experiences.

In the paradigm of the experience economy a key role is played by the concept of experience marketing. Dziewanowska and Kacprzak (2013, p. 87) define this notion as company activity which, on the basis of experiences important for the customer, builds bonds between the brand and the consumer, based on deep emotions. This, in turn, translates into the increased affection towards the company and attachment to its trade offer. LaSalle and Britton (2003, p. 30) believe that the most important element of the concept are the interactions between the buyer and the company or its product, the main aim of which is to evoke the customer's specific emotional reaction. According to Boguszewicz-Kreft (2020, p. 37), experience marketing consists in stimulating the buyer's senses and triggering his or her emotional reactions to the company's activities. 
Pacsi and Szabo (2018, p. 120) indicate that the objective of experience economy is to create exceptional experiences which are moved from the consumer's short-term memory to his or her long-term memory. To produce the effect of involvement, experiences created by a company should influence the mind and senses of customers (Sundbo, 2009). According to Gentile et al. (2007), the customer's engagement should be built on a few layers: rational, emotional, sensory, physical, and even spiritual. In turn, Pine II and Gilmore (1998) defined an experience as a sensation which a consumer considers to be personal, unique and permanent. Tulving (1983) remarks that we remember those experiences which involve intensive emotions.

To create experiences evoking emotional reactions towards the brand, storytelling activities are used. Tarczydło (2017, p. 26) defines marketing storytelling as a way of conveying an idea by means of a tale. The main advantage here is that the idea is communicated in an accessible and illustrative way, which usually draws the recipient's attention, arousing his or her interest and increasing the chances of memorizing the message. The results of a study conducted by Kang, Hong and Hubbard (2020, pp. 52-53) show that the more the participants of an experience feel they take part in the events of the story told, the more highly they evaluate its creativity, reasonableness and emotional impact.

To give experiences a more interactive character, gamification is used. According to Czerska (2016, p. 280), this concept means the use of game-design to involve people in different tasks in the real world, which thus makes it possible to manage their engagement. Detering et al. (2011) point out that the gamification technique is based on pleasure from taking on challenges, rivalry, cooperation and achievements in the game. Du Vall (2018) emphasizes the fact that gamification allows elements of fun to be included in activities which have not previously been associated with anything pleasant. Thus, gamification may prove to be particularly useful in encouraging the young generation to get involved in social initiatives.

Pine II and Gilmore (1998) proposed a classification of experiences based on two dimensions. The first of them defines the level of the consumer's participation in an experience, in which he or she can assume an active role (influencing the course of an experience) or passive role (being just the observer of an experience). The other dimension identifies the degree of how deeply the consumer is involved in the experience environment. It could be absorption (when the consumer is somehow beyond the experience environment, e.g., being the spectator of a sporting event) or immersion (when the consumer is inside the experience, e.g., participating in a sports competition). Thus, we can distinguish four types of experiences:

- Escapist - experiences based on immersion and active participation;

- Educational - experiences based on absorption and active participation;

- Entertainment - experiences based on absorption and passive participation;

- Aesthetic - experiences based on immersion and passive participation.

Researchers believe that companies should offer experiences from different areas in order to create unforgettable sensations in their customers' minds. 
Dziewanowska and Kacprzak (2013, p. 99) point out that, in practice, different types of experiences combine, e.g., "Education" and "Entertainment" together become "Edutainment", while "Education" and "Escapism" combine into "Eduscapism".

\section{Virtual reality technology}

Virtual reality (VR) technology, on account of its characteristics, is a particularly useful social marketing tool in the sphere of experience creation. This concept refers to a medium consisting of interactive computer simulations, sensing its user's position and actions, and, based on this, offering him or her the feeling of immersion or presence in a simulated, virtual world (Sherman, 2003, p. 13). Grudzewski et al. (2018, p. 39) point out that modern VR technology is composed of two elements. The first is hardware, i.e., the VR system consisting of few components: a head-mounted display, motion controllers and additional peripheral devices, which enhance the capacity of the VR system. The other element is software, which provides the environment of virtual simulation.

In 2021, at the initiative of the European Commission (2021), as part of the activities aimed at counteracting the extinction of insect pollinators and environmental protection, an interactive experience in virtual reality - in the form of the VR application "Pollinator Park" - was developed. Among the creators were communications agencies specializing in the production of VR films and applications (Poppins and Wayne, Cousteau, ESN) and European cultural and research institutions (Naturalis Biodiversity Center, Royal Belgian Institute of Natural Sciences, Museum of Natural Sciences of Barcelona). "Pollinator Park" was created in cooperation with the Belgian architect Vincent Callebaut (2015), who designs futuristic buildings, taking into consideration the sustainable development doctrine. "Pollinator Park" is available for free via the online platform www.oculus.com (Oculus, 2021).

The experience of "Pollinator Park" shows a vision of the world in 2050, which "following a cascade of ecological crises, has been deprived of pollinating insects, healthy ecosystems and wealthy flora" (European Commission, 2021). In this dystopian world, every participant of the virtual experience can explore the ecological ark - a complex of futuristic buildings the task of which is to protect pollinating insects and raise the visitors' ecological awareness.

"Pollinator Park" is an example of the implementation of social marketing tenets. According to the classification proposed by Pine II and Gilmore (1998), this experience, based on immersion and active participation, can be categorised as "Escapism."

Using the example of this VR application, we analysed VR technology in terms of its benefits and limitations to use as a tool for shaping awareness and pro-ecological attitudes, influencing the food market and biodiversity of the natural environment. 


\section{Benefits}

The "Pollinator Park" application strongly stimulates the user's senses of sight and hearing. Visual and auditory stimuli are provided to its user by the head-mounted display (HMD). People using VR equipment see a stereoscopic image giving the impression of the depth of space and three-dimensionality of objects. They hear a binaural spatial sound, which allows them to identify its source in the virtual environment. Hackl and Wolfe (2017, p. 20) note that owing to this sound technology, it is possible to turn the user's attention to a specific element of the narration, as intended by the virtual experience director. Markowski (2021, p. 95) stresses the positive relationship between the intensity of sensations and a sense of immersion (Pardel, 2009, pp. 41-42) in the virtual environment.

The exploration of the virtual environment is embedded in the story told by two narrators, who are our guides in the "Pollinator Park." The male voice focuses on explaining facts concerning the phenomena and relationships between human activity and the condition of pollinating insects and their influence on the quality and availability of food products. The female voice, belonging to Dr Beatrice Kukac, scientist and founder of the park, tells a personal tale of fascination with nature, lasting since childhood, the establishment of the ecological ark and the importance of natural biodiversity in the emotional and spiritual aspect. The user's involvement is thus built on a few levels (rational, sensory, emotional, spiritual), in line with the concept of experience marketing proposed by Gentile, Spiller and Noci (2007).

VR experience users can interact with various elements of the virtual environment of the "Pollinator Park." For example, they can manually pollinate plants, by carrying pollen from one plant to another. This action makes them aware how busy pollinating insects are. The user can also interact with numerous three-dimensional visualizations presenting methods of insect pollinator protection (e.g., home gardening principles, the role of green areas in urban space). The use of interaction elements in the VR experience helps to cause the recipient's emotional reaction (LaSalle and Britton, 2003, p. 30).

While visiting the "Pollinator Park" the experience users can do a quiz to check their knowledge of pollinating insects. Moving around the park, they gather the pieces of Dr. Beatrice Kukac's diary, discovering the story of the ecological ark. By collecting at least five of ten diary pieces, they unlock access to the final location of the park. Du Vall (2018) indicates that the application of traditional computer game elements in the VR experience may have a positive influence on the level of users' engagement.

In one of the available locations of the "Pollinator Park", there is a place where the user can see what shopping and breakfasts will look like in the dystopic vision of a world devoid of pollinating insects. Selecting different dates from 2020 to 2080 , the user can observe how on-shelf availability and the contents of the breakfast plate change. Approaching a shelf with products, the experience user can listen to the narrator's explanation concerning the relationship between pollinating insects and a given food product. Gawlik (2018, p. 265) points out that 
strong sensory stimuli, interactive engagement and a sense of participation in the virtual environment translate into emotional involvement; thus, virtual reality makes its users empathise and triggers changes of attitudes.

The findings of the study carried out by Bailenson reveal the potential of virtual reality in terms of strengthening the ties between human beings and nature (2019, p. 122). The research subject was the influence of the experience consisting in chopping down trees in the woods on changing pro-ecological behaviours. One group of participants took part in the simulation of chopping down trees in virtual reality. The second group watched a first-person point-of-view video recording showing how a tree is chopped down. The third group, in turn, read a testimony describing the impressions which accompany chopping down trees. The participants were also asked about the evolution of their pro-ecological behaviours after the experience of chopping down a tree. The study findings showed that VR technology not only leads to a bigger shift of behaviours towards pro-ecological attitudes than in the case of the application of other media, but this change also has a more permanent character.

Nelson et al. (2020) reached similar conclusions following a study in which they showed the participants the ecological importance of coral reefs, and asked them to donate to an ecological organization. The researchers found their request for a donation more effective when it was made by means of a 360-degree VR movie rather than being presented in a written form.

\section{Limitations}

There is no doubt that a limitation of the use of VR technology as a tool for promoting contents is its technological exclusivity. Despite the steadily growing number of users, VR systems are still relatively expensive and are therefore rather unpopular, even among the young generation. That is why VR technology has currently little reach when it comes to content distribution. This reach may be increased if VR technology is used as an educational tool at schools, training centres, cultural institutions and at special social and cultural events.

The "Pollinator Park" experience is available in virtual reality only via VR systems by Oculus Rift and Oculus II. Although the "Pollinator Park" application is also available on Mac and PC computers - supported by Chrome, Edge and Firefox browsers - it is a totally different experience without the characteristics of virtual reality.

The "Pollinator Park" is offered in a few language versions (English, French, German, Dutch and Spanish). The lack of other language versions may be another barrier to use.

As far as the functional area is concerned, the "Pollinator Park" application does not have a multi-person mode. The option of interacting with other users could enrich the exploration of the virtual environment with an element of shared experience, where a community is focused around a specific idea (Skorek, 2017, p. 244). Nevertheless, it is worth integrating a VR experience with other, 
collective forms of raising ecological awareness, such as moderated discussion or an Oxford debate.

The "Pollinator Park" application does not stimulate the sense of touch, although the equipment it is supported by does provide such a functionality. In some VR experiences of a similar type, when the user touches objects in the virtual environment, they feel vibrations emitted by the motion controllers they hold in their hands. The application of this solution could extend the scope of the user's sensory impressions, giving the VR experience the additional dimension of interaction. No other commercial VR system available in the market provides the stimulation of the other two senses (taste and smell).

\section{Conclusions}

Industrial agriculture and environmental degradation are significantly contributing to the extinction of pollinating insects. The size of the population of pollinators, in turn, influences prices and availability of food products and floral diversity. To stop this trend, the ways of using the resources of the natural environment must be changed, in line with the doctrine of sustainable development.

Pro-ecological awareness and attitudes can be shaped through social marketing activities. What is of particular importance in this area is the concept of experience marketing, a tool of which is virtual reality technology.

The analysis of virtual reality technology, conducted on the example of the "Pollinator Park" VR experience, shows that VR meets the assumptions of experience marketing in practice and may constitute an effective tool for shaping attitudes and behaviours that influence the food market and the natural environment. However, due to the innovative character of the tool, it cannot reach a mass audience. What may increase its reach in future is the highly probable growth in the popularity and affordability of VR systems.

It is worth carrying out further empirical studies aimed at verifying the potential of the "Pollinator Park" VR application for shaping consumers' awareness and pro-ecological attitudes, and for finding out how permanent such a transformation will be.

\section{References}

Bailenson J., 2019. Wirtualna rzeczywistość. Doznanie na żądanie. Helion SA, Gliwice. Barrionuevo A., 2007. Honeybees Vanish, Leaving Keepers in Peril. The New York Times (https://www.nytimes.com/2007/02/27/business/27bees.html; access: 22.06.2021).

Bekić B., Jeločnik M., Subić J., 2014. Honey Bee Colony Collapse Disorder (Apis mellifera L.) - Possible Cause. Economic Engineering in Agriculture and Rural Development 14(2): 13-18.

Biesmeijer J.C., Roberts S.P.M., Reemer M., Ohlemüller R., Edwards M., Peeters T., Schaffers A.P., Potts S.G., Kleukers R., Thomas C.D., Settele J., Kunin W. E., 2006. Parallel 
Declines in Pollinators and Insect-Pollinated Plants in Britain and the Netherlands. Science 313(5785): 351-354.

Boguszewicz-Kreft M., 2020. Marketing doświadczeń. CeDeWu, Warszawa.

Breeze T.D., Bailey A.P., Balcombe K.G., Potts S.G., 2011. Pollination services in the UK: how important are honeybees? Agriculture, Ecosystems and Environment 142: 137143.

Callebaut V., Andrieu-Millagou C., 2015. Paris 2050 - Les cités fertiles face aux enjeuxdu XXIe siècle. Michel Lafon, Neuilly-sur-Seine.

Cummins J., 2007. Requiem for the honeybee. Science in Society 34: 37-38.

Crenna E., Sala S., Polce C., Collina E., 2017. Pollinators in life cycle assessment: towards a framework for impact assessment. Journal of Cleaner Production 140(2): 525-536.

Czerska I., 2016. Grywalizacja jako narzędzie zarządzania zaangażowaniem konsumenta. Marketing i zarządzanie 45(4): 279-286.

Deterding S., Sicart M., Nacke L., O’Hara K., Dixon D., 2011. Gamification. using game-design elements in non-gaming contexts (https://doi.org/10.1145/1979742.1979575).

Du Vall M., 2018. Grywalizacja jako klucz do zwiększenia zaangażowania młodego pokolenia w działania społeczne. Państwo i Społeczeństwo 1: 85-100.

Dziewanowska K., Kacprzak A., 2013. Marketing doświadczeń. Wydawnictwo Naukowe PWN, Warszawa.

Gallai N., Vaissière B.E., 2009. Guidelines for the economic valuation of pollination services at a national scale. FAO, Rzym (http://www.fao.org/3/at523e/at523e.pdf; access: 22.06.2021).

Gawlik K., 2018. Wirtualna rzeczywistość - potencjał wykorzystania w budowaniu relacji z klientami. Przedsiębiorczość i Zarządzanie 19(5), 2: 255-269.

Gentile C., Spiller N., Noci G., 2007. How to Sustain the Customer Experience: An Overview of Experience Components that Co-create Value with the Consumer. European Management Journal 25(5): 395-410.

Gliński Z., Kostro K., 2007. Zespół masowego ginięcia pszczół nową groźną chorobą pszczoły miodowej. Życie weterynaryjne 82(8): 651-653.

Goodland R., Ledec G., 1987. Neoclassical economics and principles of sustainable development. Ecological Modelling 38(1-2): 19-46.

Greenpeace, 2015. Nie tylko miód Wartość ekonomiczna zapylania upraw rolniczych w Polsce w roku 2015 (https://www.greenpeace.org/poland/raporty/2236/raport-nietylko-miod-wartosc-zapylania-upraw-rolniczych-w-2015r/; access: 22.06.2021).

Grębowski R., 1997. Marketing społeczny w ochronie środowiska. Ekonomia i Środowisko 1(10): 63-67.

Grudzewski F., Awdziej M., Mazurek G., Piotrowska K., 2018. Virtual Reality in Marketing Communication - the Impact on the Message, Technology and Offer Perception - Empirical Study. Economics and Business Review 4(18), 3: 36-50.

Hackl C., Wolfe G., 2017. Marketing New Realities: An Introduction to Virtual Reality \& Augmented Reality Marketing, Branding, \& Communications. The Marketing Futurists, Kindle Edition.

Kahneman D., Tversky A., 1979. Prospect Theory: An Analysis of Decision under Risk. Econometrica 47: 263-291.

Kang J., Hong S., Hubbard G.T., 2020. The role of storytelling in advertising: Consumer emotion, narrative engagement level, and word-of-mouth intention. Journal of consumer behaviour 19(1): 47-56.

Kevan P.G., Phillips T.P., 2001. The economic impacts of pollinator declines approach to assessing the consequences. Conservation Ecology 5(1): 8 (http://www.consecol.org/ vol5/iss1/art8; access: 22.06.2021). 
Klein A.M., Vaissiere B.E., Cane J.H., Steffan-Dewenter I., Cunningham S.A., Kremen C., Tscharntke T., 2007. Importance of pollinators in changing landscapes for world crops. Proceedings of the Royal Society of London B: Biological Sciences 274(1608): 303-313.

Kolbert E., 2014. The Sixth Extinction: An Unnatural History, Henry Holt and Co., New York.

Komisja Europejska, 2021. Pollinator Park (https://ec.europa.eu/environment/pollinator-park pl\#ecl-inpage-897; access: 22.06.2021).

Kukuła K., 2015. Porównanie międzyrankingowe państw UE ze względu na wybrane elementy biogospodarki w 2012 roku. Problemy Rolnictwa Światowego 15(3): 93-101.

LaSalle D., Britton T.A., 2003. Priceless: turning ordinary products into extraordinary experiences. Harvard Business School Press, Boston.

Lawson T., 2013. What is this 'school' called neoclassical economics? Cambridge Journal of Economics 37(5): 947-983 (https://doi.org/10.1093/cje/bet027).

Leonard R.J., Pettit T.J., Irga P., McArthur C., Hochuli D.F., 2019. Acute exposure to urban air pollution impairs olfactory learning and memory in honeybees. Ecotoxicology 28: $1056-1062$.

Lenderman M., 2006. Experience the Message: How Experiential Marketing is Changing the Brand World. Carrol \& Graf, New York.

Majewski J., 2016. Pszczoły w biogospodarce - znaczenie i wartość ekonomiczna. Roczniki Naukowe Stowarzyszenia Ekonomistów Rolnictwa i Agrobiznesu 18(4): 172-177.

Markowski M., 2021. System VR - nowa przestrzeń komunikacyjna. Folia Litteraria Polonica 1(60): 93-103.

Nelson K.M., Anggraini E., Schlüter A., 2020. Virtual reality as a tool for environmental conservation and fundraising. Plose One 15(4) (https://doi.org/10.1371/journal. pone.0223631).

Nite S., 2020. VR / AR Enterprise Insider: Guidebook for Virtual Reality and XR. Modu $\mathrm{XR}$, Torrazza Piemonte.

Oculus, 2021. Pollinator Park (https://www.oculus.com/experiences/quest/363078848 0370853; access: 22.06.2021).

Osborne J.L., 2012. Bumblebees and pesticides. Nature 491: 43-45.

Pacsi D., Szabo Z., 2018. Marketing doświadczeń, interaktywność i gamifikacja - różnice i podobieństwa między trendami światowymi. Marketing Instytucji Naukowych i Badawczych 4(30): 115-136.

Pardel P., 2009. Przegląd ważniejszych zagadnień rozszerzonej rzeczywistości. Studia Informatica 30(1): 35-64.

Pine II B.J., Gilmore J.H., 1998. Welcome to the Experience Economy. Harvard Business Review: 97-105.

Ritzer G., 2001. Magiczny świat konsumpcji. Muza, Warszawa.

Rokicki T., 2015. Produkcja owczarska jako podsystem zrównoważonej biogospodarki. Roczniki Naukowe Stowarzyszenia Ekonomistów Rolnictwa i Agrobiznesu 17(2): 208-212.

Sala S., Anton A., McLaren S.J., Notarnicola B., Saouter E., Sonessone U., 2017. In quest of reducing the environmental impacts of food production and consumption. Journal of Cleaner Production 140(2): 387-398.

Salvatore A., Smagghe G., Sweet J.B., 2021. Biosafety of bee pollinators in genetically modified agro-ecosystems: Current approach and further development in the EU. Pest Management Science 77(6) (https://doi.org/10.1002/ps.6287).

Schulp C.J.E., Lautenbach S., Verburg P.H., 2013. Quantifying and mapping ecosystem services: Demand and supply of pollination in the European Union. Ecological Indicators 36: 131-141. 
Scott J., 2000. Rational choice theory, [in:] G. Browning, A. Halcli, F. Webster (eds), Understanding Contemporary Society: Theories of the Present. SAGE Publications Ltd, Londyn, s. 126-136.

Sherman W.R., 2003. Understanding Virtual Reality. Morgan Kaufman Publishers, Burlington.

Skorek M., 2017. Motywacja klientów do zaangażowania w społeczność wokół marki. Marketing i Zarządzanie 1(47): 241-250.

Sundbo J., 2009. Innovation in the experience economy: a taxonomy of innovation organisations. The Service Industries Journal 29(4): 431-455 (https://doi. org/10.1080/02642060802283139).

Tarczydło B., 2017. Zachowania konsumenta a storytelling marki. Wybrane aspekty. Prace Naukowe Uniwersytetu Ekonomicznego we Wrocławiu 501: 24-33.

Thaler R., 1980. Toward a positive theory of consumer choice. Journal of Economic Behavior \& Organization 1(1): 39-60.

Tirado R., Simon G., Johnston P., 2013. Spadek populacji pszczół Przegląd czynników zagrażających owadom zapylającym i rolnictwu w Europie. Raport techniczny Laboratorium Badawczego Greenepace 01/2013 (https://www.greenpeace.org/static/planet4-poland-stateless/2019/06/acddaba5acddaba5-spadek_populacji_pszczol_raport. pdf; access: 22.06.2021).

Tulving E., 1983. Elements of Episodic Memory. Oxford University Press, Oxford.

Wikström S.R., 2008. A consumer perspective on experience creation. Journal of Customer Behaviour 7(1): 31-50 (https://doi.org/10.1362/147539208X290334). 



\title{
Digital loyalty strategies during the pandemic that payoff: empirical evidence from the Greek food market
}

\begin{abstract}
Purpose: Due to the ongoing pandemic, consumer behaviour is shifting fast, and a growing number of consumers are switching from physical to digital stores to limit physical interaction. This research explores the effectiveness of digital loyalty strategies in consumer food markets in the light of the ongoing pandemic and the respective increase in terms of digital adoption (DA) within the industry. In addition, this study investigates the direct effects of perceived in-store infection threat (SIT).

Design/methodology/approach: To collect data, an online self-administered survey was utilized in Greece, following the positivist approach, and 222 adult consumers of food products participated during the second COVID-19 lockdown. The method described was the most effective during the imposed restrictive measures, in terms of increasing response rates.

Findings: The findings revealed that SIT benefits the repurchase intentions (RI) associated with digital retail brands, since it exerts positive direct effects on using digital stores. Moreover, DA moderates e-consumer behaviour as DA strengthens the effectiveness of loyalty strategies.

Originality and value: To the best of the authors' knowledge, this study is the first to link the adoption of e-commerce with the effectiveness of loyalty strategies and practices in the food industry. Second, it explores the impact of SIT on RI for digital food retailers and stresses the need for firms to adopt digital business. DA was proven as a strong moderator on the effectiveness of relationship equity; thus, it underlined the need for extensive CRM campaigns for heavy users of digital platforms. The strong direct positive effects of SIT on online RI indicated a strong need for food retailers to focus on digital food networks.
\end{abstract}

Keywords: customer equity drivers, repurchase intentions, digital behaviour, pandemic, food markets

MIN - University of West Attica, Greece • melniros@yahoo.gr • @ https://orcid.org/0000-0003-0570-6312

AIN - Athens University of Economics \& Business, Greece • melniros@yahoo.gr • — https://orcid.org/0000-0003-3298-7252 


\section{Introduction}

E-food markets are facing their biggest challenge in their twenty years of life. The ongoing pandemic has caused significant changes in terms of consumers' perceptions, attitudes, activities and interests, and in general this crisis has brought about tremendous shifts in consumer behaviour (Pollak and Konecny, 2021; Svajdova, 2021). The problem which this study illustrates is how to address the basic variables that can be used to segment online consumers who are characterized by different incentives and means of approachability in terms of marketing practices and loyalty strategies. This study explores the effectiveness of customer equity drivers (CEDs) or loyalty strategies in terms of e-channel's Repurchase Intentions (RI) during the turbulent era of the ongoing pandemic in the food market. It is the first study to examine the moderating effects of digital adoption (DA) on the relationship between loyalty strategies and RI for a digital platform in the food market. Frequency of use and digital adoption (DA) are used interchangeably in this study. Last, but not least, this paper unveils the direct effects of perceived store infection threat (SIT) on a digital platform's PI. The structure of this paper is the following: in the literature review and methodology sections the authors outline the conceptual framework and justify the validity of the research method. In the findings section, we present our evidence, using regression and moderation analysis. The conclusion and limitations are presented in the final sections.

\section{Literature review}

\section{Customer equity drivers}

Customer Equity refers to the total sum of discounted net cash flows deriving from the firm's customers throughout their relationship with the company and the brand (Rust et al., 2004). In general, this total value is known in marketing literature as customer lifetime value since it depends on repurchasing the company's branded offerings (Vogel et al., 2008). The higher the repurchase intentions, the higher the customer equity. Value equity (VE), brand equity (VE), and relationship equity (RE) are the main antecedents of customer equity, also known as loyalty strategies or customer equity drivers (CEDs).

\section{Effects of CEDs on consumer behaviour}

CEDs or loyalty strategies drive future revenues, thus customer lifetime value and consequently, business profitability (Vogel et al., 2008). From a marketing perspective, loyalty strategies are critical, in terms of favourable consumer behaviour such as customer loyalty, positive word of mouth, frequency and value of orders (Rust et al., 2004). According to the theory of planned behaviour, intentions precede sales and observed customer decision-making. To forecast sales and thus 
the effectiveness of loyalty strategies and CEDs, food marketers and practitioners are required to measure repurchase intentions (Vogel et al., 2008). Since brand loyalty is incorporated in BE measurements, and in product offerings such as FMCGs, repurchase intentions are used to examine behavioural intentions (Niros et al., 2018).

As far as consumer behaviour is concerned, this is a complex phenomenon as there is a plethora of phases both prior and post purchase (Niros et al., 2018). Purchase intention is a prominent predictor of a consumer's decision-making. In practice, both researchers and managers rely on purchase intentions to figure out favourable or unfavourable behaviour (Ho and Chung, 2020). Thus, purchase intention concerns self-guided actions to purchase a product. In food markets, the formulation of purchase intention is rather complex, since incorporating attitudes, perceptions and decisions and intervention strategies should be carefully planned by managers. Brand-related attitudes and perceptions will impact the increase in sales, since previous research illustrated that, in the long term, purchase intention predicts favourable decision making (Vogel et al., 2008). Repurchase intention (RI) on the other hand, reflects intentions to buy the same brand more than once (Chaudhuri and Holbrook, 2001). In general, two types of repurchase behaviours can be found; the first being the intention to repurchase, the second being word-of-mouth opinions, whether negative or positive. This research focuses on RI related to digital food channels such as e-commerce websites, mobile apps, and online marketplaces.

\section{Basic moderators of e-consumer behaviour}

Past research has indicated that e-customer behaviour is sensitive to the adoption of e-commerce, as well as the frequency of using digital platforms. Consumers indicating higher frequency of using e-commerce and digital platforms for the purchase of a product indicate differences in terms of the criteria for reusing a digital brand, as well as different motives (Molinillo et al., 2021). Highly involved consumers in general demonstrated not only better use of digital technologies, but they were also more receptive to digital campaigns, such as newsletters, banners, gamification, and communication via emails and chatbots (Aldas-Manzano et al., 2011). Thus, it is expected that the frequency of use of digital food platforms or digital adoption will influence the positive effects of loyalty strategies on RI.

Furthermore, the pandemic has caused people to be afraid of visiting physical stores, and this has brought about turbulence and change in consumer behaviour (Svajdova, 2021). It is obvious that consumers started using digital sales channels more intensively than in the pre-pandemic era, in an attempt to eliminate infection risk. According to the study of Szymkowiak et al. (2021), perceived in-store infection threat (SIT), combined with social distancing requirements, has made it necessity for retailers to adjust their marketing practices, including the expansion of digital sales. Thus, we expect that the effectiveness of digital loyalty strategies in terms of RI will be moderated by both digital adoption (DA) and SIT in the food industry. 
Hence, we formulate the 4 following hypotheses:

- $\mathrm{H}_{1}$ : SIT exerts a positive direct effect on PI for a digital platform

- $\mathrm{H}_{2}$ : DA moderates the effectiveness of VE for e-food platforms

- $\mathrm{H}_{3}$ : DA moderates the effectiveness of BE for e-food platforms

- $\mathrm{H}_{4}$ : DA moderates the effectiveness of RE for e-food platforms

Digital Loyalty Strategies

e-customer behavioural Intentions

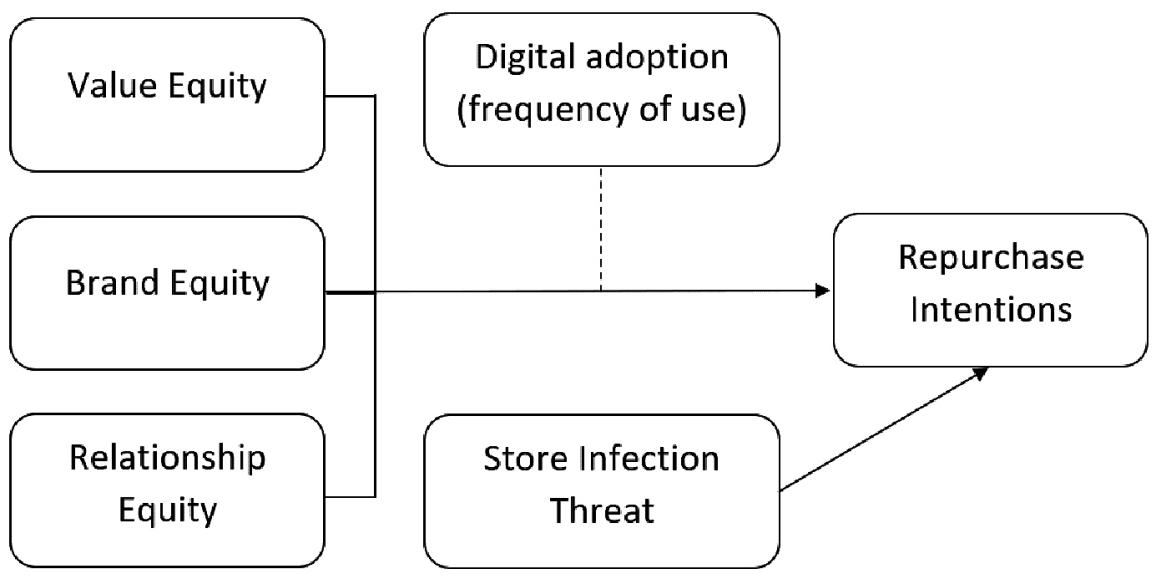

Fig. 1. Conceptual Framework

\section{Methodology}

A computer-based self-administered survey was used to collect data, utilizing a positivist approach. This method is widely used in social and business sciences, especially during the pandemic which has led to social distancing requirements. Likert-based constructs were used to minimize the error of measurement, since in self-administered surveys the completion of the questionnaire needs to be quick and well-understood. More specifically, 455 consumers of food brands were approached in Greece between February and April 2021 via email and social media. These consumers were asked to recall their last experience with a digital food retailer. If there had been no recent experience, the process was stopped (the questionnaire asked about the general e-commerce experiences of consumers that they remembered after shopping for food on their digital platform, without specifying which online retailer it was for). 222 out of 455 consumers both participated and had had a recent experience with digital food markets. The basic construct that was utilized was developed by Rust et al. (2000) and Vogel et al. (2008) and adjusted to measure the BE, VE and RE of digital sales channels. As for RI, measurement was facilitated by using the adjusted scale of Chaudhuri and Holbrook (2001). Frequency of use was also measured through a 5-point Likert scale (1: Never, 5: Always). 
As for the participants, $4.1 \%$ were between 18 and 25 years old, $29.7 \%$ belonged to the age group 26-35, and $29.7 \%$ stated they were between 36 and 45 . Participants aged between 46 and 55 years old accounted for another $29.7 \%$. The remaining $6.8 \%$ stated they were 56 or older. Regarding participants' gender, $55.4 \%$ were female and the remaining $44.6 \%$ stated they were males. Concerning the analysis, SPSS V.21 helped researchers to analyse data using factor analysis, Cronbach's alpha, multiple regression analysis, as well as moderation analysis.

Regarding the evaluation of the measurement model, we used exploratory factor analysis and Cronbach's alpha. As Table 1 illustrates, the reliability and validity of constructs were measured at satisfactory levels since most of standardized factor loadings were well above 0.70 . In addition, to check the internal validity of research constructs we used Cronbach's Alpha $(\alpha)$ test. Convergent validity is stressed by Cronbach's Alpha indexes that were far above the threshold of 0.70 .

Table 1. Reliability and validity of constructs

\begin{tabular}{|c|c|c|c|}
\hline Constructs & Original Items & $\begin{array}{l}\text { Standardized } \\
\text { regression } \\
\text { weight }\end{array}$ & $\begin{array}{c}\text { Cronbach's } \\
\text { alpha }\end{array}$ \\
\hline \multirow{4}{*}{$\begin{array}{l}\text { Brand equity } \\
\text { Rust et al. } \\
\text { (2000) } \\
\text { Vogel et al. } \\
\text { (2008) }\end{array}$} & $\begin{array}{l}B E Q 1 \text {. I recognize this digital platform is } \\
\text { a leading brand }\end{array}$ & 0.716 & \multirow[t]{4}{*}{0.746} \\
\hline & $B E Q 2$. This digital platform is attractive & 0.902 & \\
\hline & $B E Q 3$. This digital platform is unique & 0.608 & \\
\hline & BEQ4. I like this digital platform & 0.847 & \\
\hline \multirow[t]{5}{*}{$\begin{array}{l}\text { Value equity } \\
\text { Rust et al. } \\
(2000)\end{array}$} & $\begin{array}{l}V E 1 \text {. This digital platform allows me to } \\
\text { increase my knowledge about particular } \\
\text { products or usage of the products }\end{array}$ & 0.723 & \multirow[t]{5}{*}{0.828} \\
\hline & $\begin{array}{l}\text { VE2. This digital platform helps me solve } \\
\text { problems associated with product use }\end{array}$ & 0.708 & \\
\hline & $\begin{array}{l}V E 3 . \text { This digital platform helps increase } \\
\text { my understanding of particular products } \\
\text { and services by providing personalized } \\
\text { solutions }\end{array}$ & 0.883 & \\
\hline & $\begin{array}{l}V E 4 \text {. The contents of this digital platform } \\
\text { give me product/ service information } \\
\text { that is relevant to my needs }\end{array}$ & 0.765 & \\
\hline & $\begin{array}{l}\text { VE5. The contents of this digital platform } \\
\text { help me make good purchase decisions }\end{array}$ & 0.770 & \\
\hline \multirow{4}{*}{$\begin{array}{l}\text { Relationship } \\
\text { equity } \\
\text { Rust et al. } \\
\text { (2000) }\end{array}$} & $\begin{array}{l}R E 1 \text {. I have trust in this digital platform } \\
\text { for purchasing products and services }\left({ }^{*}\right)\end{array}$ & & \multirow[t]{4}{*}{0.855} \\
\hline & $\begin{array}{l}R E 2 . \text { Through this digital platform, I feel } \\
\text { this business is close to me }\end{array}$ & 0.823 & \\
\hline & $\begin{array}{l}\text { RE3. I think this business, through this } \\
\text { digital platform, makes several invest- } \\
\text { ments to improve our relationship }\end{array}$ & 0.874 & \\
\hline & $\begin{array}{l}R E 4 \text {. I think in this digital platform, this } \\
\text { firm tries to improve our relationship }\end{array}$ & 0.910 & \\
\hline
\end{tabular}


Table 1. Cont.

\begin{tabular}{|c|c|c|c|}
\hline Constructs & Original Items & $\begin{array}{l}\text { Standardized } \\
\text { regression } \\
\text { weight }\end{array}$ & $\begin{array}{l}\text { Cronbach's } \\
\text { alpha }\end{array}$ \\
\hline \multirow{4}{*}{$\begin{array}{l}\text { Frequency of } \\
\text { using digital } \\
\text { platforms }\end{array}$} & FREQ1. Frequency of use: social media & 0.578 & \multirow[t]{4}{*}{0.779} \\
\hline & FREQ2. Frequency of use: e-shop & 0.875 & \\
\hline & FREQ3. Frequency of use: Website & 0.906 & \\
\hline & $\begin{array}{l}\text { FREQ4. Frequency of use: (digital) Mar- } \\
\text { ketplace }\end{array}$ & 0.678 & \\
\hline \multirow{4}{*}{$\begin{array}{l}\text { Repurchase } \\
\text { intention } \\
\text { Chaudhuri and } \\
\text { Holbrook (2001) }\end{array}$} & $\begin{array}{l}\text { RI1. I intend to continue using this digi- } \\
\text { tal platform in the future }\end{array}$ & 0.858 & \multirow[t]{4}{*}{0.849} \\
\hline & $\begin{array}{l}\text { RI2. I would recommend this digital plat- } \\
\text { form to friends and relatives, even if they } \\
\text { are existing customers }\end{array}$ & 0.863 & \\
\hline & $\begin{array}{l}\text { RI3. I look forward to purchasing more } \\
\text { products and services from this digital } \\
\text { platform }\end{array}$ & 0.892 & \\
\hline & $\begin{array}{l}\text { RI4. I would like to have first-hand infor- } \\
\text { mation about new products and services } \\
\text { provided by this digital platform }\end{array}$ & 0.739 & \\
\hline
\end{tabular}

Notes: aFixed parameter, $\left({ }^{*}\right)$ Item deleted in validation process.

Source: The author's own elaboration.

\section{Findings}

To support or reject the hypotheses, multiple regression analysis was utilized by using PI as a dependent variable. CEDs and SIT were imported as independent variables. The ANOVA of the aforementioned model indicated a great deal of significance $(p<0.01)$. This research model explained the $29.7 \%$ of the total variance of Repurchase Intentions. Regarding the direct effects of the research model, BE and VE were not significant. Thus, it seems that digital food retailers are not required to use these loyalty strategies, for they have no effect on RI. On the other hand, RE is the most effective loyalty strategy since it is positively related to PI $(\beta=0.424, \mathrm{p}<0.001)$. Using perceived SIT as a control variable, it is evidenced that the pandemic and the resulting SIT has helped digital food retailers to attract new customers or users who order food brands via their platform, and has increased consumers' RI $(\beta=0.222, \mathrm{p}<0.05)$. Thus, $\mathrm{H} 1$ is supported by the fact that food retailers have an opportunity to expand their digital business.

Concerning the indirect effects of digital adoption (DA) or frequency of using digital platforms in the product category of foods, we utilized a moderation analysis of DA in the relationship between CEDs and RI. The interaction analysis presented in Table 2 reveals that DA can be an important moderator of e-customer behaviour. More specifically, DA in the food industry attenuates the negative (but insignificant) effect of value equity on RI. Thus, H2 is supported by facts indicating that digital adopters are experiencing higher levels of RI compared to 
consumers with lower levels of DA $(\beta=-0.270, \mathrm{p}<0.05)$. On the other hand, DA neither attenuates nor strengthens the relationship between BE and RI. Thus, $\mathrm{H} 3$ "DA of e-food digital platforms moderates the effectiveness of BE" needs to be rejected. Regarding H4 "DA of e-food digital platforms moderates the effectiveness of RE", moderation analysis indicates a significant positive effect on the relationship between RE and RI $(\beta=0.255, \mathrm{p}<0.05)$. Hence, DA strengthens the effectiveness of RE in terms of RI. Alternatively, customers with high levels of DA develop stronger Repurchase Intentions compared to customers with low levels of DA. As a result, $\mathrm{H} 4$ can be supported as well. Table 2 illustrates the multiple regression results, along with interaction analysis.

Table 2. Results of interaction analysis

\begin{tabular}{ccccc}
\hline \multicolumn{5}{c}{ Food products } \\
\hline & Regression results & Standardized coefficient & t-value & Hypothesis support \\
\hline & $\mathrm{BE} \rightarrow \mathrm{RI}$ & 0.136 & 1.139 & - \\
& $\mathrm{VE} \rightarrow \mathrm{RI}$ & -0.044 & -0.341 & - \\
& $\mathrm{RE} \rightarrow \mathrm{RI}$ & $0.424^{* * *}$ & 3.909 & - \\
$\mathrm{H} 1$ & $\mathrm{SIT} \rightarrow \mathrm{RI}$ & $0.222^{* *}$ & 2.155 & supported \\
$\mathrm{H} 2$ & $\mathrm{VE} \times \mathrm{DA} \rightarrow \mathrm{RI}$ & $-0.270^{* *}$ & -2.101 & supported \\
$\mathrm{H} 3$ & $\mathrm{BE} \times \mathrm{DA} \rightarrow \mathrm{RI}$ & 0.137 & 1.321 & rejected \\
$\mathrm{H} 4$ & $\mathrm{RE} \times \mathrm{DA} \rightarrow \mathrm{RI}$ & $0.255^{* *}$ & 2.005 & supported \\
\hline
\end{tabular}

Notes: ${ }^{* *} \mathrm{p}<0.05 ;{ }^{* * *} \mathrm{p}<0.001$, model significance $<0.001$, adjusted $\mathrm{R}^{2}=0.297$.

Source: The author's own elaboration.

\section{Conclusions and discussion}

\section{Conclusions}

The basic conclusions of this analysis concern the impact of the ongoing pandemic on e-customer behaviour. The first conclusion is that traditional food retailers encounter a great deal of threat related to risks associated with perceived in-store threat. Customers fear being infected, so they migrate to digital sales channels for their food provisions. Hence, there is an opportunity window for food retailers to grow their business in digital forms and improve digital product distribution to substitute for physical interaction. One further conclusion is the fact that DA, and more specifically the frequency of using digital channels and technologies, impacts the effectiveness of digital loyalty strategies. For instance, the effectiveness of RE is stronger for consumers with high DA, compared to consumers with low DA. This can be attributed to the fact that customers with higher levels of DA are more receptive to digital means of communication. These results are aligned with the findings of Pollak and Konecny (2021) and Svajdova (2021). Last, but not least, this research project illustrated the importance of trust and relationships in digital food markets. This is evidenced by the strong direct effects of RE on PI. The formation of strong and enduring relationships is evidenced regardless of 
the consumer's DA. However, the effectiveness of RE will generally be higher for customers that use digital channels.

\section{Discussion}

Hence, it's imperative for digital food retailers to segment their users and customers according to the frequency of using digital platforms. These findings are in accordance with the research of Aldas-Manzano et al. (2011) and Jamal et al. (2012). Since relationship equity is crucial for influencing positive behaviour, customer relationship marketing practices such as digital advertising, newsletters and interaction using chatbots and emails can be winning digital practices. This is an important aspect of this paper, since digital retailers may develop tailor-made and personalized practices according to DA. The same goes for the moderating effects of DA on the effectiveness of VE. DA attenuates brand aversion, which is important in food markets that are receptive to private labels and unbranded offerings (Gielens et al., 2021). Thus, managers should carefully plan CRM campaigns and loyalty strategies that are personalized to the characteristics of their customers, such as digital adoption.

\section{Limitations and future research}

Product category choice is limited on food digital retailers. Customer involvement with these products is considered to range from low to medium. In addition, Greece was the market where the survey was conducted, and hence the research is limited to the specific characteristics of Greek culture. Therefore, this research can be replicated in countries with different cultural features and perceptions. For future research, we propose the investigation of digital adoption on business-to-business settings, for instance hotels, restaurants and catering (HORECA), or even to consider the organic and luxury food categories and wines experiencing greater levels of customer involvement.

\section{References}

Aaker J., Fournier S., Brasel S.A., 2004. When good brands do bad. Journal of Consumer Research 31(1): 1-16.

Abadi H.R.D., Kabiry N., Forghani M.H., 2013. Analyzing the effect of customer equity on satisfaction. International Journal of Academic Research in Business and Social Sciences 3(5): 600.

Aldas-Manzano J., Ruiz-Mafe C., Sanz-Blas S., Lassala-Navarre C., 2011. Internet banking loyalty: evaluating the role of trust, satisfaction, perceived risk and frequency of use. The Service Industries Journal 31(7): 1165-1190.

Chaudhuri A., Holbrook M.B., 2001. The chain of effects from brand trust and brand affect to brand performance: the role of brand loyalty. Journal of Marketing 65(2): 81-93.

Erdem T., Swait J., Valenzuela A., 2006. Brands as signals: A cross-country validation study. Journal of marketing 70(1): 34-49. 
Gielens K., Ma Y., Namin A., Sethuraman R., Smith R.J., Bachtel R.C., Jervis S., 2021. The future of private labels: Towards a smart private label strategy. Journal of Retailing 97(1): 99-115.

Guzzo T., Ferri F., Grifoni P., 2016. A model of e-commerce adoption (MOCA): consumer's perceptions and behaviours. Behaviour \& Information Technology 35(3): 196-209.

Ho M.H.W., Chung H.F., 2020. Customer engagement, customer equity and repurchase intention in mobile apps. Journal of business research 121: 13-21.

Jamal A., Khan M.S., Tsesmetzi M.S., 2012. Information cues roles in product evaluations: the case of the UK cosmetics market. Journal of Strategic Marketing 20(3): 249-265.

Molinillo S., Aguilar-Illescas R., Anaya-Sánchez R., Liébana-Cabanillas F., 2021. Social commerce website design, perceived value and loyalty behavior intentions: the moderating roles of gender, age and frequency of use. Journal of Retailing and Consumer Services: 102404.

Nawaz Z., Ahmad M., Piracha S., Raza M., 2017. Customer equity of Pakistani fast-food restaurant: A study of attitudinal customer equity. Management Science Letters 7(2): 87-96.

Niros M.I., Ding Q.S., Pollalis Y., Niros A.I., 2018. Marketing strategies in foreign markets sensitive to consumer ethnocentrism and confidence: Empirical evidence from Greece. European Marketing Academic Annual Conference.

Pollak F., Konecny M., 2021. Analysis of E-Consumer Behaviour - Selected Findings from an Analysis of Czech E-Shops and their Customers during the Global Pandemic, [in:] SHS Web of Conferences 90. EDP Sciences.

Razzaq Z., Yousaf S., Hong Z., 2017. The moderating impact of emotions on customer equity drivers and loyalty intentions: evidence of within sector differences. Asia Pacific Journal of Marketing and Logistics.

Rust R.T., Lemon K.N., Zeithaml V.A. 2004. Return on marketing: Using customer equity to focus marketing strategy. Journal of Marketing 68(1): 109-127.

Svajdova L., 2021. Consumer Behaviour during Pandemic of COVID-19. Journal of International Business Research and Marketing 6(3): 34-37.

Szymkowiak A., Gaczek P., Jeganathan K., Kulawik P., 2021. The impact of emotions on shopping behavior during epidemic. What a business can do to protect customers. Journal of Consumer Behaviour 20(1): 48-60.

Vogel V., Evanschitzky H., Ramaseshan B. 2008. Customer equity drivers and future sales. Journal of Marketing 72(6): 98-10. 



\title{
Mirosława Pluta-Olearnik
}

\section{The role of social media influencers in building a brand's authority in the food market}

\begin{abstract}
Purpose: To identify ways of building the authority of food and culinary brands using the activities of influencers-experts in the field of healthy eating and healthy lifestyle.

Design / methodology / approach: The research used a qualitative research method called the multiple case research study. The selection of cases for the study was deliberate; four brands were intentionally identified in which references to the authority of a personal brand were used in marketing communication on social media.

Findings: Analyses have shown that the food and culinary market is a specific segment that is sensitive to the perception of brand image under the impact of influencers-experts. Originality: The phenomenon of the impact of influencer activities associated with healthy food and healthy lifestyles intensified at the start of the COVID-19 pandemic and has continued in subsequent periods, with selected social media tools as a tool of influence.
\end{abstract}

Keywords: branding, food market, social media, influencer marketing

\section{Introduction}

Brands play a significant role in how businesses and buyers operate in the marketplace. With the growing popularity of social media, the interaction of media users and potential buyers with brand content is becoming a key element of a company's online presence and market success.

Observing a brand online through social media brings benefits in terms of increasing brand awareness. Moreover, engaged consumers make a contribution, become co-creators of the brand, and co-create the brand's authority.

The aim of this study is to identify ways of building the authority of food and culinary brands based on the concept of influencer marketing. The concept of brand authority is thus related to the activities of influencers-experts in the field of healthy eating and healthy lifestyle. 
The considerations are based on an analysis of four selected case studies of active influencers, which enables more reliable findings to be obtained than would be possible with the analysis of a single case study. Analyses have shown that the food and culinary market is a specific segment that is sensitive to the perception and evaluation of the image of brands under the impact of influencers-experts. This phenomenon intensified with the onset of the COVID-19 pandemic and continued in subsequent periods.

\section{The brand as an object of research}

The author of "Brand book", Wally Olins, noted that: "We love brands because they make life more attractive and easier, and because we define ourselves through them. We like the complex mix of functions and feelings in them. We like the way they complement and express our personality" (Olins, 2009).

It is difficult to give an exact and unambiguous definition of a brand that would fully reflect the brand. A brand is a marketing tool that has a multidimensional and invaluable impact on sales and communication with the customer. In the literature, a brand is most often understood as a name, term, sign, symbol or design, as well as a specific combination of these elements. At the same time, a brand is much more than that: it is a declared promise to consistently provide the customer with a specific set of product features, benefits and services (Kotler et al., 2005). A strong brand gives a competitive advantage on the market and the buyer is willing to pay more for it. The strongest brands that meet buyers' expectations appeal to something more than rationality; they primarily affect emotions (Kotler et al., 2005). Through the purchase of specific brands, the buyer creates an image of his or her own self, choosing brands with personalities consistent with his or her actual or desired image (Kall et al., 2013).

A brand has peculiar qualities that build its capital. From a marketing perspective, the brand capital bears responsibility for the evaluation and perception of this brand by buyers, i.e. what this brand means to consumers (Dębski, 2009). The elements that make up the brand capital are perceived brand quality, brand awareness, brand prestige, and other assets, such as trademarks, patents, etc. (Urbanek, 2003).

The perceived brand quality is the level of quality attributed by consumers to products with a given brand and is determined by internal factors (functions, functional features, guarantee, packaging, durability, compliance with specifications) and external factors (advertising, other promotional tools, price, brand name and its positioning) (Witek-Hajduk, 2011). Brand awareness, in turn, is the buyer's ability to identify a brand and associate this brand with a specific product category. Brand awareness is the basis for building its image, personality and familiarizing potential buyers with the benefits offered by this brand (Kędzior, 2003). The perceived prestige of a brand, on the other hand, is the buyers' belief that the brand and the products labelled with it are unique and superior 
in functional, emotional and cognitive terms, when compared to other brands available on the market (Gammoh et al., 2011).

Brands which are considered to be the most effective fulfil a lot of functions and are an important alternative with regard to the tangible and financial investments of a company, mainly because they make it possible to achieve a significant return on the capital that has been invested.

\section{The role of the Internet in building brand awareness and brand image}

Until recently, traditional media, such as television, radio, press and outdoor advertising, were most often used to build brand awareness and image. However, the intensive development of technology, widespread digitisation and the huge popularity of the Internet have meant that Internet marketing tools now play a crucial role in the process of building brand awareness and image. Today, many brands on the market are present only in the virtual space, which proves that the Internet is a medium with a huge potential.

The tools most often used to build brand awareness and image on the Internet are:

- websites (a business card of a brand, company, product, person on the Internet - it plays the role of conveying information and image),

- social networking sites (tools for transmitting information, reaching customers and engaging them in discussions and various activities),

- video services (tools creating the brand image through the publication of advertising spots, promotional videos, both formal and less formal),

- display advertising campaigns in popular portals (popular promotions) and AdWords campaigns (ads can take two forms - text and graphics, they are accounted for in two models: per click - CPC (Cost Per Click) or per number of displays of the ad - CPM (Cost Per Mile)".

- blogs and microblogs (forming opinions about the brand, creating an appropriate atmosphere and communicating brand values).

The term "social media" was introduced in 2005 to describe new media available for use by all Internet users. The main idea of social media was to enable dialogue and continuous interaction between users. Social media have become an integral part of the modern world. Social networks are used by more than two billion people worldwide. Thus, it has become the most powerful marketing tool. It gives the business community a greater chance to be present, to succeed and to get to know the potential customer better. It gives the opportunity to build awareness, increase coverage, obtain customer data and companies interested in the offer, communicate with the customer and collect fans. It is important to maintain social media profiles dynamically. It is necessary to be in constant contact with customers, to provide them with relevant content and entertainment that will interest them enough to stay as long as possible. Those responsible for running social media channels have a lot of work to do due to constantly changing trends and news. 


\section{The development of influencer marketing}

Trends in social media channels are constantly changing. The recent period has strongly increased audience expectations and the pandemic is largely responsible for this. The lives of many people have changed dramatically, they had to get used to a completely different reality than the one they faced before. This has had an impact on people's expectations of brands and the content that they communicate on their social profiles.

The community places more trust in influencers, who decide, for example, to cooperate and promote individual brands, well-tested by them, and not those who base their social profiles only on advertising. The profiles that are most appreciated tend to show naturalness, rather than those where you can find a lot of posed and excessively retouched photos (Żyłakowska, 2021).

Following this trend, influencer marketing has also developed in the food and culinary market, where pro-health, pro-environment and pro-social trends have emerged with full clarity.

Influencer marketing refers to a specific marketing tactic that is based on communicating the brand image with the help of opinion leaders called influencers (Wyrwisz, 2019). In other words, it involves the search for popular and influential people in a particular field and working with them to promote a brand/ product by using the community organized around that person (Wilusz, 2017).

The main social networks that are the domain of influencer activities are:

- Photo sites, which are used to publish photos online and where other users can like, comment and evaluate the galleries created. An example of this type of service is the application and website Instagram (9 million users in Poland). The photo-taking function is also used in the equally popular Snapchat application.

- Services with video files, which are used to upload video recordings. The leader for years has been YouTube (19.8 million users). Organisations can create their own channels and share up-to-date content. Independent vloggers also publish their recordings on the YouTube platform. The most popular vloggers (so-called influencers) have 1-2 million subscribers, so they are a very interesting group for companies to establish business cooperation with. Running a vlog has turned from a hobby into a source of income.

- Micro-video services are used to post short, split-second videos and graphics online. Currently, one of the largest platforms of this type is Snapchat (1.9 million users) and Instagram with the InstaStory function, where users can post stories that are deleted after 24 hours. The popularity of the TikTok mobile application, whose main functionality consists in the possibility of sending very short video clips, similar in content to music videos, is also growing rapidly.

- Social networks that aim to establish and maintain contacts, and exchange information between users. The most popular service in 2021 is Facebook with 22 million users in Poland (https://napoleoncat-social-media- statistics-instagram-users-in-poland_2021_10). It offers the possibility to run a website and a blog. Facebook also gives its users (especially influencers) and organisations 
the possibility to run fanpages, on which they can engage and interact with their fans by means of the content they post (e.g. texts, films, live reports, photos and graphic materials).

Influencers can be divided by three criteria: reach, type and content (GóreckaButora et al., 2019).

Reach refers to the number followers:

- Top influencers - above 500 thousand people,

- Macro influencers - between 100 and 500 thousand people,

- Medium influencers- between 20 and 100 thousand people,

- Micro influencers - no more than 20 thousand people,

- Nano influencers - from 1000 to max. 10 thousand people.

Type focuses on the kind of influencers in the network, taking into account their motivation, level of knowledge, experience and involvement in the subjects they address:

- Idols - people who are very popular not only among their fans but also among people who do not follow their social media profiles on a daily basis. They enjoy recognisability and have a large coverage on the Internet.

- Experts - influential people who have authority among their audience in a particular field. They build the most engaged and loyal communities.

- Lifestylers - people who post content about the spheres of everyday life, achieve coverage smaller than idols, but larger than experts. They post mostly on Instagram and have blogs.

- Activists - these are social activists with a defined world view. Their topics of interest include ecology and minority rights. Recipients appreciate their courage, authenticity and uncompromising approach to life. They publish their content on Facebook, Twitter and blogs.

- Artists - their activity focuses on creating content with high aesthetic and visual appeal. They publish content on Instagram and run photoblogs. The main topics they cover are travel, nature, people, architecture, design and fashion. Content refers to the type of material the influencer publishes on the platform through which they communicate with their audience, for example:

- YouTubers communicate through video content.

- Facebookers constitute a large number of opinion leaders; they can easily communicate with huge audiences through text, photos and videos.

- Instagrammers locate products using photos, hashtags and InstaStories.

- Twitterers run microblogs with an opinionated and journalistic character.

- TikTokers are the youngest group of influencers, whose content is communicated through short videos to a specific musical setting.

- Streamers (Twitch) share live streaming video content.

\section{Food brand authority in the era of social media - a case study}

The foundations of social media are interpersonal relations, thanks to which network users provide each other with personal opinions about various brands, and 
thus, often unconsciously, play the role of marketers. This phenomenon contributes to the growth of brand awareness, makes it possible to reach a huge number of users, generating an increase in the sale of products online and in-store (Dorenda-Zaborowicz, 2012).

The effectiveness of social media is largely due to the process of building social authority. It is created and developed when a company or an individual defines themselves as a professional (expert) in a particular field and is able to influence the exchange of views, contributing to its enrichment.

The best reception of the brand by Internet users takes place when the trust and authority of the brand is built reliably, i.e. on the basis of sincere intentions and knowledge in a given field, and the valuable information offered is not obviously characterised by commercial assumptions.

If the above requirements are fulfilled, the brand's message on the Internet (social media) will develop naturally, the sender will become an authentic leader who communicates trusted values and norms to recipients, and the recipients will trust in the reliability of intentions.

If the above understanding of building the authority of a food brand in social media is adopted, it can be concluded that influencers play the role of:

- brand ambassador - a given food product starts to be associated with the values and behaviours of the influencer,

- trendsetter - sets trends and models behaviours, thanks to which promoted food products become attractive to buyers, give a sense of prestige.

Building brand-consumer relationships in the context of authority is strongly related to the personality traits of the influencer. The influencer-authority personality should be (Kuczamer-Kłopotowska and Piekarska, 2018):

- engaging - creates the need for frequent contact across multiple communication platforms

- active - builds constant, close, friendly contact with the follower

- expert - has full knowledge of the product, is authentic, builds an impression of a reliable product recommendation

- selective - carefully considers cooperation proposals from brands.

For the purposes of the comparative analysis, the selection of four cases of influencers in the food and culinary category was based on: 1) their activity on the Internet, confirmed by the highest reach of influence, i.e. the number of observers of their profiles on such social media as: Facebook, Instagram, YouTube, as well as on their website; and 2) having the specific personality traits of an influencer - an authority on the food and culinary market.

The aim of the case studies was to identify ways of building brand authority in the food and culinary market using social media tools. The selection of cases for the study was intentional, i.e. the aim was to look for brand cases in which references to personal brand authority were used in social media marketing communications, built on the basis of a person's image.

In exploratory research, theoretical case selection is sufficient. This means that cases are selected deliberately, due to their particular usefulness in exposing relationships between the studied constructs and findings that allow generalization 
in the analytical sense (as theoretical claims), but not in the statistical sense (as frequency of occurrence) (Hajdas, 2019).

The data for the study was obtained using methods such as: 1) analysis of the content available online on the profiles of selected influencers - experts in the area of so- called healthy food and cooking; and 2) analysis of qualitative data, in which the process of categorization (personality traits of the authority) was used. The comparison of influencers' personalities is presented in Table 1.

The research question was formulated as follows: what are the means of action on social media of the brand based on the personal authority of the so-called influencer-expert, on the example of the food and culinary market? The results of the analysis of influencers selected for the study are presented in Tables 1, 2 and 3.

Table 1. Comparison of the personality traits of influencers on the food and cooking markets

\begin{tabular}{|c|c|c|}
\hline $\begin{array}{l}\text { Influencers - } \\
\text { authorities }\end{array}$ & $\begin{array}{l}\text { Features of the } \\
\text { personality of } \\
\text { an influencer }\end{array}$ & Examples of actions \\
\hline \multirow[t]{4}{*}{$\begin{array}{l}\text { Anna } \\
\text { Lewandowska }\end{array}$} & engaging & $\begin{array}{l}\text { She keeps in touch across multiple platforms: } \\
\text { Instagram ( } 3.5 \text { million followers) } \\
\text { - Facebook ( } 1 \text { million } 766 \text { thousand followers) } \\
\text { - You Tube channel ( } 50 \text { thousand subscriptions) } \\
\text { - Website - Foods by Ann shop } \\
\text { - Blog Healthy Plan by Ann } \\
\text { - Diet E Training by Ann app }\end{array}$ \\
\hline & active & $\begin{array}{l}\text { She publishes content on the Internet related to: physical } \\
\text { activity (original trainings), her business Food by Ann (pro- } \\
\text { ducts), recipes of her original diet, and interesting facts } \\
\text { from her private life. }\end{array}$ \\
\hline & expert & $\begin{array}{l}\text { She is gradually building her image as a fitness trainer, } \\
\text { nutritionist, businesswoman, book publisher and sports } \\
\text { activist. }\end{array}$ \\
\hline & selective & $\begin{array}{l}\text { A well-thought-out strategy for action on the Internet } \\
\text { for healthy living and healthy eating. }\end{array}$ \\
\hline \multirow[t]{4}{*}{$\begin{array}{l}\text { Ewa } \\
\text { Chodakowska }\end{array}$} & engaging & $\begin{array}{l}\text { She keeps in touch on selected platforms: } \\
\text { - Facebook ( } 2 \text { million } 50 \text { thousand observers) } \\
\text { - Instagram ( } 1.9 \text { million observers) } \\
\text { - You Tube channel ( } 280 \text { thousand subscriptions) } \\
\text { - Website - BeBio shop }\end{array}$ \\
\hline & active & $\begin{array}{l}\text { The topics of the films published on the Internet are very } \\
\text { similar to those presented by Lewandowska, i.e. mainly } \\
\text { physical activity (the author's workouts) and healthy, } \\
\text { dietetic food. }\end{array}$ \\
\hline & expert & $\begin{array}{l}\text { She successively builds her image: mainly as a fitness tra- } \\
\text { iner and author of trainings, and as a businesswoman (her } \\
\text { own online shop BeBio) }\end{array}$ \\
\hline & selective & $\begin{array}{l}\text { A well-thought-out online action strategy for a healthy } \\
\text { lifestyle. }\end{array}$ \\
\hline
\end{tabular}


Table 1. Cont.

\begin{tabular}{|c|c|c|}
\hline $\begin{array}{l}\text { Influencers - } \\
\text { authorities }\end{array}$ & $\begin{array}{l}\text { Features of the } \\
\text { personality of } \\
\text { an influencer }\end{array}$ & Examples of actions \\
\hline $\begin{array}{l}\text { Magda } \\
\text { Gessler }\end{array}$ & engaging & $\begin{array}{l}\text { She is described by internet users as a "social media nin- } \\
\text { ja". Active on the following platforms: } \\
\text { - Facebook ( } 1 \text { million } 500 \text { thousand observers) } \\
\text { - Instagram ( } 1 \text { million } 100 \text { thousand observers) } \\
\text { - Fanpage on FB (over } 860 \text { thousand fans) } \\
\text { - You Tube channel ( } 88 \text { thousand subscriptions) } \\
\text { - She has recently launched a TikTok channel with videos } \\
\text { present on TVN channels, }\end{array}$ \\
\hline
\end{tabular}

active As an active user of social media, Magda Gessler publishes videos related to the TV show Kuchenne Rewolucje (Kitchen Revolutions), numerous posts, leads a lively discussion on her fanpage, and also appears in many memes.

expert Restaurateur and TV personality, businesswoman. She hosts her own TV show Kitchen Revolutions (since 2010), is a juror of MasterChef and Food Network (until 2019).

selective In her programmes, she persuades restaurant owners and viewers to switch to natural products and healthy food, supports traditional and regional food, quality food.

Anna engaging
Starmach

active

expert

selective
She keeps in touch on selected platforms:

- Instagram (580 thousand observers)

- You Tube channel (194 thousand subscriptions)

- Facebook (193 thousand observers) and she is present on the TVN and TVN Style channels, and on RMF radio

On social media she publishes photographs of the dishes she prepares, her own recipes and short films about healthy cooking. She also hosts a TV cooking show Pyszne 25. She is the author of culinary books. On RMF Classic radio, she hosts the programme Healthy day!.

She won the competition "Gotuj o wszystko" ("Cook for everything") (2010, TVN), she gained recognition thanks to her participation as a juror in the TV programmes MasterChef and MasterChefJunior. She was trained in the Parisian school Le Cordon Bleu.

On her You Tube channel, she hosts a cooking show "Superfoods for Everyday" about healthy and easy cooking in collaboration with the Purella food brand.

Source: The author's own compilation based on personal brands' and company influencers' profiles on social media platforms: Instagram, Facebook, YouTube, websites - quantitative data taken as of 10.11.2021. 
Table 2. Comparison of the activities of influencers - fitness trainers, businesswomen

\begin{tabular}{|c|c|c|c|}
\hline $\begin{array}{l}\text { Influencer - } \\
\text { Expert }\end{array}$ & $\begin{array}{l}\text { Categories of food } \\
\text { market products }\end{array}$ & Assortment & Channels of sales \\
\hline $\begin{array}{l}\text { Anna } \\
\text { Lewandowska }\end{array}$ & $\begin{array}{l}\text { - natural healthy } \\
\text { food free from } \\
\text { artificial additives } \\
\text { supplements } \\
\text { cooking } \\
\text { (recipes/dish } \\
\text { presentations) }\end{array}$ & $\begin{array}{l}\text { The brand's entire range is } \\
\text { composed of raw materials } \\
\text { from reliable sources, with } \\
\text { quality that guarantees good } \\
\text { taste and an abundance of } \\
\text { nutrients. They include: } \\
\text { gluten-free breads, cookies, } \\
\text { nut butters, natural energy } \\
\text { drinks, bars, chocolate, tre- } \\
\text { ats, superfoods, smoothies, } \\
\text { gluten free muesli, butters } \\
\text { and oils, soups, puddings, } \\
\text { supplements. }\end{array}$ & $\begin{array}{l}\text { - Internet shop } \\
\text { Foodsbyann.com. } \\
\text { Products under this } \\
\text { brand were/are sold } \\
\text { in Polomarket, Lidl } \\
\text { (seasonally), Auchan, } \\
\text { Carrefour, Żabka } \\
\text { shops, points of sale } \\
\text { at Shell, Lotos and } \\
\text { PKN Orlen stations. } \\
\text { and on the Internet } \\
\text { - Costa Coffee (bars). } \\
\text { - Dietetic catering } \\
\text { BodyChief }\end{array}$ \\
\hline $\begin{array}{l}\text { Ewa } \\
\text { Chodakowska }\end{array}$ & $\begin{array}{l}\text { - healthy food, } \\
\text { dietetic food } \\
\text { - supplements } \\
\text { - recipes (recipes/ } \\
\text { presentations of } \\
\text { dishes) }\end{array}$ & $\begin{array}{l}\text { The brand's range is based } \\
\text { on organic products, inclu- } \\
\text { ding: bars, fit cakes, healthy } \\
\text { drinks (shots), nut creams, } \\
\text { nuts and dried fruit, herbs } \\
\text { and supplements. In addi- } \\
\text { tion, there is clothing and } \\
\text { exercise equipment on offer. }\end{array}$ & $\begin{array}{l}\text { - Internet shop BeBio.pl } \\
\text { - with an offer of } \\
\text { healthy food and } \\
\text { cosmetics, } \\
\text { - Dietetic catering } \\
\text { BeDiet }\end{array}$ \\
\hline
\end{tabular}

Source: Personal and company brand profiles on social media platforms: Instagram, Facebook, YouTube, author's websites - data taken as of 10.11.2021.

Table 3. Comparison of influencer activity - culinary experts, businesswomen

\begin{tabular}{|c|c|c|c|}
\hline $\begin{array}{l}\text { Influencer - } \\
\text { Expert }\end{array}$ & $\begin{array}{l}\text { Product catego- } \\
\text { ries of the food } \\
\text { market }\end{array}$ & Assortment & Sales channels \\
\hline $\begin{array}{l}\text { Magda } \\
\text { Gessler }\end{array}$ & $\begin{array}{l}\text { Food natural, } \\
\text { organic cuisine }\end{array}$ & $\begin{array}{l}\text { Delicatessen products: natural } \\
\text { cheeses, fruit preserves, } \\
\text { pickles, vegetable preserves, } \\
\text { pressed juices, jarred meals, } \\
\text { dried mushrooms. Dietetic } \\
\text { catering packed in boxes }\end{array}$ & $\begin{array}{l}\text { Delicatessen www. } \\
\text { delikatesy.ufukiera.pl } \\
\text { - Dietetic catering Body } \\
\text { Chief (Diet by Magda } \\
\text { Gessler) }\end{array}$ \\
\hline $\begin{array}{l}\text { Anna } \\
\text { Starmach }\end{array}$ & $\begin{array}{l}\text { Food healthy, or- } \\
\text { ganic superfoods } \\
\text { cuisine (recipes/ } \\
\text { advice, videos on } \\
\text { cooking dishes) }\end{array}$ & $\begin{array}{l}\text { She promotes Purella's so- } \\
\text {-called Superfood products as } \\
\text { natural, exceptionally healthy } \\
\text { food, the consumption of } \\
\text { which has a beneficial effect } \\
\text { on the functioning of the hu- } \\
\text { man body (these are products } \\
\text { such as: goji or acai berries, } \\
\text { quinoa, coconut water, flaxse- } \\
\text { ed, amaranth, chia seeds), }\end{array}$ & $\begin{array}{l}\text { - YouTube channel } \\
\text { - 2021- season 3) - } \\
\text { cooking dishes using } \\
\text { Purella superfoods } \\
\text { products } \\
\text { - Website aniastarmach. } \\
\text { pl (recipes, blog, tips, } \\
\text { no sale) }\end{array}$ \\
\hline
\end{tabular}

Source: Personal and company brand profiles on social media platforms: Instagram, Facebook, YouTube, author's websites - data taken as of 10.11.2021. 


\section{Conclusions}

Two opposing consumption trends are currently being observed. The first is the pro-consumption orientation, which is similar to the phenomenon of excessive consumption, while the second trend refers to limiting consumption in favour of its rationalisation. The second lifestyle, which promotes moderation in consumption, care for health and a healthy lifestyle, as well as respect for the natural environment (ecology, limiting waste), plays an increasingly important role.

We are observing a trend known as smart shopping and smart cooking. Consumers are taking their time to gather information about products and their features in order to make the right choice and not be manipulated by advertising. In order to gather such information, consumers now have tools at their disposal to make purchasing decisions. These tools include online price comparison services, blogs, consumer forums and social networking sites. The popularity (reach) of influencers present in social media is growing.

The authority of a product brand in the era of social media can be effectively built on the food and culinary market through the help of activities of influencer marketing. The power of influencers' impact is based on their personality traits, which create the authority of a brand present on the food and culinary market. Influencers build the awareness and image of their own food brands or the brands they work with. In addition to the obvious trait of expert knowledge in the field of nutrition and healthy lifestyle, influencers' characteristics, such as constant engagement in various social networks, above-average activity in communication with media users, especially fans, and - as revealed by the pandemic - selectivity in the selection of cooperation partners are also important.

The best reception of the brand by Internet users takes place when the trust and authority of the brand is built reliably, i.e. on the basis of sincere intentions and knowledge of a given area, and the offered valuable information is not characterised by purely commercial assumptions. This phenomenon is strengthened in the period of the so-called new pandemic and post-pandemic reality.

\section{References}

Dębski M., 2009. Kreowanie silnej marki. PWE, Warszawa.

Dorenda-Zaborowicz M., 2012. Marketing w social mediach. Nowe Media 3/2012. Uniwersytet Mikołaja Kopernika, Toruń.

Gammoh B., Koh A.C., Okoroafo S.C., 2011. Consumer culture brand positioning strategies: An experimental investigation. Journal of Product and Brand Management 20(1): 48-57 (https://doi.org/10.1108/10610421111108012).

Górecka-Butora P., Strykowski P., Biegun K., 2019. Influencer Marketing od A do Z. Whitepress, Bielsko-Biała.

Hajdas M., 2019. Kodeksy kulturowe i relacje wartości marki - badania eksploracyjne i implikacje badawcze. Management Sciences 24(1).

Kall J., Kłeczek R., Sagan A., 2013. Zarządzanie marką. Oficyna Wydawnicza, Warszawa. 
Kędzior Z., 2003. Konsument na rynku. Postawy wobec produktów. Centrum Badań i Ekspertyz Akademii Ekonomicznej Katowice.

Kotler P., Vong V., Saunders J., Armstrong G., 2005. Principles of marketing. FT Prentice Hall, Harlow.

Kuczamer-Kłopotowska S., Piekarska K., 2018 Realizacja funkcji influencer marketingu W opinii influencerów oraz followersów. Zarządzanie i Finanse 16(3), 3: 159-173.

Olins W., 2009. Brand book. Podręcznik brandingu. Instytut Marki Polskiej, Warszawa.

Urbanek G., 2002. Zarządzanie marką. PWE, Warszawa.

Witek-Hajduk M., 2011. Zarządzanie silną marką. Oficyna Wolters Kluwer Business, Warszawa.

Wilusz R., 2017. Influencer marketing potężny ponad miarę. Nowe techniki, pomysły, rozwiązania. Oficyna Wydawnicza Politechniki Rzeszowskiej, Rzeszów.

Wyrwisz J., 2019. Influencer marketing w komunikacji marketingowej marki (http://hdl. handle.net/11331/2978; access: 24.11.2021).

Żyłakowska K., 2021. Trendy w social media na rok 2021 (https://socialpress.pl/2021/01/ trendy-w-social-media-na-rok-2021; access: 24.11.2021). 



\title{
Marcin Adam Antoniak
}

\section{Nutrition and health claims (2000-2020): a systematic literature review}

\begin{abstract}
Purpose: the present study aims to determine the current state of knowledge related to the use of nutrition and health claims (NC and HC, respectively) on food packaging. Design/methodology/approach: a Scopus database search enabled an examination of three groups of articles published between 2000 and 2020, formed according to the presence of two phrases in the titles, abstracts, or keywords: NCs and HCs, at least NCs and at least HCs. The study was based on the methods of Massaro (2016) and Paul and Criado (2020).
\end{abstract}

Findings: the study revealed two important groups of topics covered in the analysed articles: factors influencing the perception of claims (health, taste, trust, education, demographic data), as well as the perception of claims by consumers - a particularly controversial topic due to inconclusive results.

Practical implications: the article might prove helpful for indicating potential directions for further research on claims and contribute to their better understanding by consumers. Therefore, it may lead to the improvement of eating habits and consequently to the reduction of civilization diseases. As such, the article can be used both by business practitioners and researchers analysing academic papers on claims.

Originality and value: the strength of this article lies in an in-depth analysis of an extensive database of articles, but also in the broad description of topics covered therein, as well as the suggestions for potential directions of future studies.

Key words: nutrition claims, NCs, health claims, HCs, food claims, systematic review

\section{Introduction}

Poor diets have become a serious problem in numerous highly-developed countries. As a result, these countries have seen a huge increase in chronic diseases. Some of them were directly related to stress, lifestyle, as well as improper nutrition. Therefore, proper nutrition has become one of the modifiable elements of

MAA - Poznań University of Economics and Business, Institute of Marketing, Department of Commerce and Marketing •

marcin.antoniak@phd.ue.poznan.pl• • io https://orcid.org/0000-0003-0920-9540 
lifestyle, essential to maintaining good health (FAO and World Health Organization, 1998).

Social awareness of the importance of health prevention is gradually increasing. This is reflected in the growing trend of buying and consuming products with better nutritional components (Krystallis et al., 2008). However, consumers are surrounded by unhealthy food, which impedes making good food choices (Hill et al., 2003). With a view to helping them decide properly, many countries have introduced legislation allowing producers to label food with nutrition claims (NCs) and health claims (HCs). Consequently, claim-bearing products have been appearing in an increasing number of countries (Grunert et al., 2010).

According to the Food and Agriculture Organization of the United Nations (FAO), the term nutrition claim refers to "any claim that states, suggests or implies that a food has particular nutritional properties, including, but not limited to, energy value and protein, fat and carbohydrate content as well as the content of vitamins and minerals" (Food and Agriculture Organization of the United Nations, 2012). NCs are sometimes confused with HCs, which according to the FAO (2012) refer to any statement about a relationship between food and health.

Since the introduction of nutrition and health claims (NHCs) legislation, an estimated $26 \%$ of packaged food in Europe contains some form of claim (Hieke et al., 2016). Kreuter et al. (1997) argue that there is a link between nutritional practices and the appearance of nutrition labels. This has been confirmed by Drichoutis et al. (2006), who have shown that people interested in well-being and healthy eating focus more on products with additional nutritional benefits (Urala, 2005). According to Kaur (2017), such food is chosen more often than identical products without adequate information. This may increase the likelihood of purchasing (Aschemann-Witzel and Hamm, 2010) or consuming claim-bearing food (Cavaliere et al., 2015). Hence, for most consumers, such readily available information as NHCs constitutes the main source of knowledge about food products (Provencher and Jacob, 2016). Furthermore, as confirmed by Talati et al. (2016), nutrition claims are one of the main sources of nutritional information for many consumers, thus constituting one of the crucial factors taken into consideration when making purchasing decisions (Ginon et al., 2009). Yet, consumers would undoubtedly appreciate and use claims to a greater extent if they were more easily available (Ballco et al., 2019).

Recent years have seen an increase in the number of articles about NHCs. Various authors have confirmed that familiarity with NHCs significantly influences consumers' purchasing intentions and decisions (Oostenbach et al., 2019). However, the presence of NHCs on the packaging may go unnoticed by customers unfamiliar with their meaning (Bazhan et al., 2017). Nonetheless, there is also evidence to the contrary, indicating that claims may adversely affect intentions (Bialkova et al., 2016) and purchasing decisions (Kiesel and Villas-Boas, 2013).

The presence of claims may lead to reducing the guilt associated with buying food that is considered unhealthy (Cornish, 2012) and, accordingly, to increasing its consumption (Belei et al., 2012). All this suggests that consumers often 
misunderstand the message of NHCs (Persoskie et al., 2017), or are not entirely aware of their meaning. Such discrepancies in study findings have raised interest among researchers (Kaur et al., 2017), making them argue that further analyses on this topic are necessary in order to determine the genuine role of NHCs (Meyerding and Merz, 2018; Peschel et al., 2019).

Despite a considerable interest in the topic, there are still very few reviews directly addressing NHCs. One of them is De Boer and Bast's (2015) article on European NHCs, which reviews the legislation typical of twenty-eight countries. Another study focuses on the impact of claims on food choices (Kaur et al., 2017); it evaluates seventeen articles, according to which NHCs increase purchases and/ or consumption. Steinhauser and Hamm (2018), having examined sixty-six articles, identify consumer characteristics affecting their behaviour in relation to claim-bearing products. Finally, Ostenbach et al. (2019), on the basis of eleven articles, analyse NHCs, but selected ones, namely those regarding fat, sugar, and energy value. Overall, the reviews have revealed that NHCs may influence not only consumers' health and taste perceptions of analysed products, but also their intentions to buy claim-bearing food.

In the light of the increase in the number of studies on NHCs, the author's aim is to fill the research gap concerning a lack of extensive bibliometric analyses regarding both types of claims. Although some works in this area already exist, they either deal with only one type of claim, or focus on a limited number of articles. Therefore, the author intends to present a broad and in-depth analysis based on a well-known and widely-accepted method, namely structured review (Paul and Criado, 2020).

\section{Methods}

Systematic literature review takes three basic forms, namely domain-based, theory-based, and method-based (Paul and Criado, 2020). The first form may be further subdivided into: structured review, bibliometric review, framework-based review, hybrid-narrative review and review aiming at model/framework development (Paul and Criado, 2020). In addition, there is non-systematic review, known as meta-analysis.

According to this classification, the present paper represents the bibliometric review. All analyses were performed in 2021 and cover the period of 2000-2020. Only two keywords were selected for the study - nutrition claims and health claims. Overall, 196 articles with the keyword NCs, 1588 with HCs and 98 containing both keywords (not including scientific, regulatory, and legal opinions issued mainly by European Food Safety Authority and US government agencies) were analysed in the study.

The strength of the present research consists in its being a systematic literature review (SLR) (Paul and Criado, 2020) focusing on an in-depth content analysis. Furthermore, it is based on Scopus analysis of all the articles that contained the selected keywords, regardless of when they were published (Zaheer 
et al., 2019). Scopus is a comprehensive database, including most of the journals indexed in WoS (Mongeon and Paul-Hus, 2016).

\section{Content analysis}

\section{Use of nutrition and health claims over the years}

Since the introduction of NHCs into the legal nomenclature of the US in 1996 and the European Union in 2006, consumer interest in claims has been steadily increasing (Sajdakowska et al., 2019; Steinhauser et al., 2019; Tugault-Lafleur and Black, 2019). Subsequently, the number of publications on this subject has also been steadily increasing. The exact number of publications per year, not including technical-scientific, regulatory, and legal opinions, is shown in Figures 1-2.
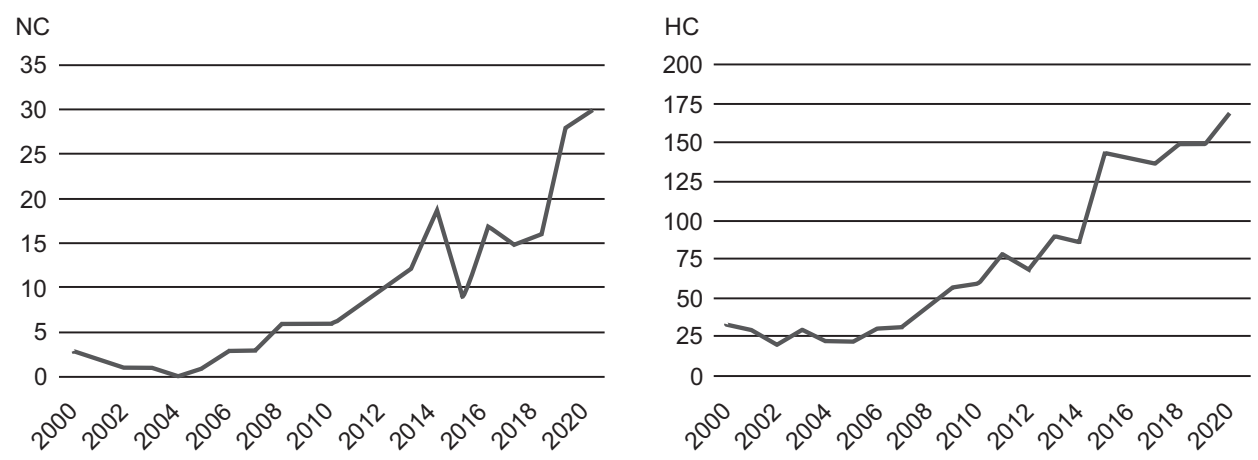

Figs 1-2. Publications per year

Source: The author's own study.

The analysis of the most cited articles indicates that the total number of citations largely depends on the top ten articles. It is particularly visible in the group searched by NC and by both analysed terms. In these cases, $51 \%$ and $43 \%$ of all citations, respectively, refer to the top ten articles. In turn, as far as the group of articles searched by the phrase $\mathrm{HC}$ is concerned, the percentage amounts to $11 \%$. Yet, this should also be considered as high, as the number of analysed articles exceeds 2,000. What might prove thought-provoking is the fact that the most cited articles are not necessarily those appearing at the beginning of the analysed period. While most frequently cited articles containing both keywords were published in 2009, for those with either NC or HC this was the case in 2006. More detailed information is provided in Table 1.

It is evident that the frequency of claims usage varies greatly between countries. This might stem from cultural and legal differences (Hieke et al., 2016). For instance, in Canada the percentage has been calculated at $46 \%$ (Franco-Arellano et al., 2018), with the increase of front-of-pack (fop) nutrition claims on baby products of $31.4 \%$ to $86.6 \%$ between 2009 and 2017 (Elliott, 2019). In turn, in 
Lithuania only $15.7 \%$ of products contain NCs (Murniece and Straumite, 2014), whereas in Mongolia this is true for only $10 \%$ of products (Chimedtseren et al., 2020). As far as bakery products are concerned, claims are present on $56.3 \%$ of 1565 of these in New Zealand (Al-Ani et al., 2016), and 59.6\% of bread in Lebanon, with 32.5\% representing NCs and $15.3 \%$ HCs (Bou-Mitri et al., 2020). Furthermore, the average percentages for five European countries (the Netherlands,

Table 1. Citations per title

\begin{tabular}{|c|c|c|c|}
\hline \multicolumn{4}{|c|}{$\mathrm{HC}$} \\
\hline Title & DOI & Year & ${ }^{*}$ cit \\
\hline $\begin{array}{l}\text { Relation between age and car- } \\
\text { diovascular disease in men and } \\
\text { women with diabetes compared } \\
\text { with non-diabetic people: a popu- } \\
\text { lation-based retrospective cohort } \\
\text { study }\end{array}$ & $10.1016 / \mathrm{S} 0140-6736(06) 68967-8$ & 2006 & 481 \\
\hline $\begin{array}{l}\text { The biasing health halos of fast- } \\
\text { food restaurant health claims: } \\
\text { Lower calorie estimates and higher } \\
\text { side-dish consumption intentions }\end{array}$ & $10.1086 / 519499$ & 2007 & 438 \\
\hline $\begin{array}{l}\text { Incidence of and risk factors for } \\
\text { chronic opioid use among opi- } \\
\text { oid-naive patients in the postoper- } \\
\text { ative period }\end{array}$ & 10.1001/jamainternmed.2016.3298 & 2016 & 411 \\
\hline $\begin{array}{l}\text { Tissue distribution of quercetin in } \\
\text { rats and pigs }\end{array}$ & $10.1093 / \mathrm{jn} / 135.7 .1718$ & 2005 & 363 \\
\hline $\begin{array}{l}\text { Race differences in the age at } \\
\text { diagnosis among medicaid-eligible } \\
\text { children with autism }\end{array}$ & $10.1097 / 00004583-200212000-00016$ & 2002 & 358 \\
\hline $\begin{array}{l}\text { The perceived healthiness of } \\
\text { functional foods: A conjoint study } \\
\text { of Danish, Finnish and American } \\
\text { consumers' perception of function- } \\
\text { al foods }\end{array}$ & 10.1016/S0195-6663(02)00171-X & 2003 & 331 \\
\hline $\begin{array}{l}\text { Galacto-Oligosaccharides: Produc- } \\
\text { tion, properties, applications, and } \\
\text { significance as prebiotics }\end{array}$ & 10.1111/j.1541-4337.2010.00119.x & 2010 & 331 \\
\hline $\begin{array}{l}\text { "Smoking revolution": A content } \\
\text { analysis of electronic cigarette } \\
\text { retail websites }\end{array}$ & 10.1016/j.amepre.2013.12.010 & 2014 & 326 \\
\hline $\begin{array}{l}\text { Health and disability costs of } \\
\text { depressive illness in a major U.S. } \\
\text { corporation }\end{array}$ & 10.1176/appi.ajp.157.8.1274 & 2000 & 301 \\
\hline $\begin{array}{l}\text { Consumer responses to an off-fla- } \\
\text { vor in juice in the presence of } \\
\text { specific health claims }\end{array}$ & 10.1016/S0950-3293(01)00076-3 & 2002 & 257 \\
\hline
\end{tabular}


Table 1. Cont.

\begin{tabular}{|c|c|c|c|}
\hline \multicolumn{4}{|c|}{ NC } \\
\hline Title & DOI & Year & $*^{*} \mathrm{cit}$ \\
\hline $\begin{array}{l}\text { Can "low-fat" nutrition labels lead } \\
\text { to obesity? }\end{array}$ & 10.1509/jmkr.43.4.605 & 2006 & 449 \\
\hline $\begin{array}{l}\text { Consumer appeal of nutrition and } \\
\text { health claims in three existing } \\
\text { product concepts }\end{array}$ & 10.1016/j.appet.2009.03.007 & 2009 & 169 \\
\hline $\begin{array}{l}\text { FAO Technical meeting on prebi- } \\
\text { otics }\end{array}$ & N/A & 2008 & 164 \\
\hline $\begin{array}{l}\text { Nutritional characterization and } \\
\text { measurement of dietary carbohy- } \\
\text { drates }\end{array}$ & 10.1093/jn/135.7.1718 & 2007 & 152 \\
\hline $\begin{array}{l}\text { Effects of nutrition facts panel } \\
\text { values, nutrition claims, and health } \\
\text { claims on consumer attitudes, per- } \\
\text { ceptions of disease-related risks, } \\
\text { and trust }\end{array}$ & 10.1509/jppm.19.2.213.17133 & 2000 & 138 \\
\hline $\begin{array}{l}\text { Are some comparative nutrition } \\
\text { claims misleading? The role of } \\
\text { nutrition knowledge, ad claim type } \\
\text { and disclosure conditions }\end{array}$ & $10.1080 / 00913367.2000 .10673615$ & 2000 & 126 \\
\hline $\begin{array}{l}\text { How package design and pack- } \\
\text { aged-based marketing claims lead } \\
\text { to overeating }\end{array}$ & 10.1093/aepp/pps028 & 2013 & 98 \\
\hline $\begin{array}{l}\text { Perceived relevance and foods with } \\
\text { health-related claims }\end{array}$ & 10.1016/j.foodqual.2011.10.006 & 2012 & 77 \\
\hline $\begin{array}{l}\text { Health-related ad information and } \\
\text { health motivation effects on prod- } \\
\text { uct evaluations }\end{array}$ & 10.1016/j.jbusres.2013.05.001 & 2014 & 62 \\
\hline $\begin{array}{l}\text { Effects of food package information } \\
\text { and sensory characteristics on the } \\
\text { perception of healthiness and the } \\
\text { acceptability of enriched biscuits }\end{array}$ & 10.1016/j.foodres.2012.03.016 & 2012 & 60 \\
\hline
\end{tabular}

the UK, Germany, Slovenia, Spain) amounts to $21 \%$ for HCs and $11 \%$ for NCs (Hieke, Kuljanic et al., 2016).

As a matter of fact, claims appear not only on products considered healthy (Franco-Arellano et al., 2018; Kaur et al., 2016). For instance, although $95 \%$ of ultra-processed products sold in Australia contain sugar additives, an estimated $56 \%$ of them contain NCs and $25 \%$ - HCs (Pulker et al., 2018). Moreover, the use of claims depends on other factors, such as product category and the information conveyed. For example, juices are characterised by particularly frequent use of claims, reaching up to 97\% (Duffy et al., 2021). The most significant NCs are believed to inform about calories, vitamins, proteins, carbohydrates, and fibre (de Sousa et al., 2020). Thus, despite the intention of many countries and 
international organisations to limit the unhealthy eating habits of consumers, the use of NHCs could still be improved. In the light of this context, it would be worthwhile to conduct a study that would indicate the use of claims on selected products over a longer time period.

\section{Attention, attitude, perception, behaviour}

The use of claims influences the approach and reactions to products, for they significantly affect perceptions in terms of health, attractiveness, and taste (Gravel et al., 2012; Lähteenmäki et al., 2010). In the light of the emergence of claims, consumers should pay attention to products containing them, and this is liable to impact final purchasing decisions to a considerable extent (Bialkova et al., 2014; Samant and Seo, 2016). NHCs may also have a visible impact on consumer preferences and purchasing behaviour (Kaur et al., 2017). Nevertheless, their acceptance may depend on knowledge and the overall perception of claim-bearing products (Sandmann et al., 2015).

HCs are more diverse and sometimes more complex than NCs, which might explain Steinhau ser et al.'s (2019) finding that consumers spend more time reviewing the former. Nonetheless, other studies have shown that NHCs do not necessarily influence consumer perception and behaviour, or may even have a negative impact (Aschemann-Witzel and Grunert, 2015; Bialkova et al., 2016; Orquin and Scholderer, 2015). Hence, there is a large discrepancy in the results obtained by different researchers (Hieke et al., 2015; Kaur et al., 2017), which reflects the need for further research on customer perceptions, attitudes, or attention towards claims and products containing them.

\section{Healthy/unhealthy products and health perception}

Consumers seem to perceive food in terms of healthiness, or lack thereof (Larkin and Martin, 2016; Orquin and Scholderer, 2015). The likelihood of selecting products with claims, which are generally perceived as healthier (Benson et al., 2019), has been estimated to be $75 \%$ higher than that of products without them (Kaur et al., 2017). This may result from consumers' understanding of products and from their expectations (Hamilton et al., 2008; Lähteenmäki et al., 2010). However, NHCs are intended to help consumers make the right food choices by aiding them to identify healthier products (Hawley et al., 2013; Thorndike et al., 2012). Hence, consumers with a particular interest in health and a balanced diet are more likely to be interested in health-related information (Colby et al., 2010; Hoppert et al., 2014), including claims. This provides greater incentives to buy claim-bearing products (Bialkova et al., 2014).

The role of claims is particularly significant among people with health problems (Barreiro-Hurlé et al., 2010; Cavaliere et al., 2015), who are more motivated to study product information, including claims, in a more diligent way (Lähteenmäki, 2013). If customers perceive NHCs as having a positive effect on their well-being, they show a greater interest in products containing them (Cavaliere et 
al., 2015; Dean et al., 2012), which affects actual consumer behaviour. Moreover, consumers whose relatives or friends suffer from a disease also show more interest in claims (Lalor et al., 2011).

Consumers may react differently to claim-bearing products, especially when dealing with food considered healthy (Bialkova et al., 2016; Fenko et al., 2016) or unhealthy (Gravel et al., 2012; Maubach et al., 2014). The perceived healthiness may significantly affect both the assessment of such products and purchasing behaviour (Stancu et al., 2017; Talati et al., 2016). Most studies show that the greatest efficiency of claims is observable in the case of healthy products (Oliveira et al., 2018). Their visibility on such products is also more preferable (Choi et al., 2012; Fenko et al., 2016) and may boost consumer perception (Roseman et al., 2018).

However, there are studies providing evidence to the contrary. They point out that claims cannot have a great effect on the perception of products considered healthy, precisely because they are already considered healthy (Krutulyte et al., 2011). Furthermore, NHCs may even render perceptions unreliable, due to the uncertainty as to why healthy products require additional information confirming their quality (Turnwald et al., 2017).

On the other hand, the presence of claims on unhealthy products may ameliorate their credibility and health-related perception (Ikonen et al., 2020). Hence the greater tendency to buy them (Talati et al., 2016). Consequently, a certain cognitive dissonance created among consumers may enhance the image of unhealthy products (Egnell et al., 2018; Ikonen et al., 2020), thus leading to their increased consumption. This increase may also result from the reduction of guilt associated with unhealthy junk food (Cornish, 2012; Lampila et al., 2009), or from the justification of an unhealthy diet (Belei et al., 2012). Nevertheless, Lalor et al. (2011) argue that while the presence of claims on healthy products increases their credibility, it provokes scepticism in the case of unhealthy ones. However, this might equally be related to the general unreliability of NHCs, which interferes with preferences (Bialkova et al., 2016) and purchasing intentions (Tugault-Lafleur and Black, 2019) regarding claim-bearing products.

It can be observed that inconclusive results surround the perception of claims and their impact on the products on which they are placed. These ambiguities may result from the fact that the very perception of products determines their assessment and purchasing behaviour (Bialkova et al., 2016; Stancu et al., 2017). However, there is still no hard data showing the actual impact of claims on the perceptions of products considered healthy or unhealthy (Talati et al., 2016). Due to the aforementioned discrepancies, it is also impossible to unequivocally determine the influence of claims on attitudes, intentions, or behaviour towards such products. Further research on this issue is yet to be conducted.

\section{Claims vs. taste}

Taste is frequently viewed as one of the most influential purchasing factors (Kourouniotis et al., 2016; Kowalkowska et al., 2018). It is the perception of taste that may significantly influence the perception of healthy and unhealthy products 
(Lähteenmäki, 2013) and guide food choices (Kourouniotis et al., 2016; Kowalkowska et al., 2018). This stems from the belief that healthy products with different types of claims are blander (Benson et al., 2019) and less palatable (Choi and Reid, 2018; Suzuki and Park, 2018). Hence, health-related claims may reduce consumption, owing to their association with poorer taste (Berning et al., 2011; Raghunathan et al., 2006). Although the taste perception of claim-bearing products might vary depending on their general perception, there is still a lack of studies analysing large numbers of differently-perceived products. Such research might enable a more precise assessment of the actual impact of claims on taste perception.

\section{The role of knowledge and education}

Knowledge about NHCs is considered to be one of the key factors influencing the perception of food claims (Carrillo et al., 2014; Lähteenmäki, 2013). Women, especially those with lower incomes, are arguably more knowledgeable about this topic because they more often read food-related information (Benson et al., 2019; Bou-Mitri et al., 2020), shop, and prepare meals (Hassan and Dimassi, 2020). Despite a strong correlation between the knowledge of claims and consumer preferences (Giacalone and Jaeger, 2016), also reflected in better perceptions of products with familiar claims (Carrillo et al., 2014; Miklavec et al., 2015), there is considerable variability in both the level of knowledge and the resulting attitudes. It is believed that these attitudes are more positive in the US than in Europe, which may be related to the fact that in the US claims were introduced in 1996, while in Europe this happened ten years later (Aschemann-Witzel and Grunert, 2015).

The perception of claims also varies as a function of education. Although the interest in claims may be greater among groups of people with lower levels of education (Barreiro-Hurlé et al., 2010; Cavaliere et al., 2015), some studies show that this factor is irrelevant in the context of consumer preferences (Contini et al., 2015; Vecchio and Cavallo, 2019). In addition, consumers appear to have difficulty understanding nutritional information (Malloy-Weir and Cooper, 2017; Persoskie et al., 2017). This is a plausible reason for stronger preferences for claims written in a simple way (Bitzios et al., 2011; Lähteenmäki et al., 2010). Hence, it is essential to educate consumers about the role and meaning of NHCs in order for them to be more effective.

\section{Gender, age, and other demographic data}

Numerous studies show that age, gender, and other demographic data influence the attractiveness of claim-bearing products (Bimbo et al., 2017; Siegrist et al., 2015). It is also claimed that gender, age, and consumer knowledge affect the use of nutrition labels, and, accordingly, food claims (Bryla, 2020). Women tend to buy in response to claims more often than men (de Sousa et al., 2020). Such variability might translate into purchasing decisions (Bou-Mitri et al., 2020). Furthermore, it is believed that older consumers are more interested in claim-bearing 
products (Cavaliere et al., 2015; Dean et al., 2012) and are more prone to buying them (Baglione et al., 2012; Vecchio and Cavallo, 2019).

Nonetheless, opposing studies imply that demographic data fail to influence purchasing decisions (Aschemann-Witzel and Grunert, 2015; Urala and Lähteenmäki, 2007). Demographic or socioeconomic variables may not be significant predictors for reading food labels, including food claims (Bryla, 2020). More indepth investigation is still needed in this topic.

\section{Problems with understanding}

Nutrition labels may be too complex to be understood properly (Grunert, Wills et al., 2010). Having read labels and tried to understand them, many consumers find them difficult to interpret correctly (Cowburn and Stockley, 2005). In turn, some consumers may only partially process food information, omitting more difficult parts (Oliveira et al., 2016). Hence, consumers tend to prefer simple (Bitzios et al., 2011) and familiar claims (Lähteenmäki et al., 2010), which may result in greater interest in claims when making purchasing decisions (Campos et al., 2011). This problem also pertains to distinguishing NCs from HCs (United States Government Accountability Office, 2012), especially among less educated consumers (Malloy-Weir and Cooper, 2017; Persoskie et al., 2017). There is a need for guidelines to be issued for lawmakers and food producers, with a view to increasing customer understanding of the role and functionality of claims.

\section{Trusting claims}

Consumer confidence in claims is recognised to be one of the key determinants of food choices (Annunziata et al., 2016; Ding et al., 2015), leading to consumer acceptance of food (Strijbos et al., 2016). The more consumers value a healthy lifestyle and a healthy diet, the greater their intentions to purchase claim-bearing products (Bower et al., 2003), and, accordingly, the greater their confidence in NHCs themselves (Russo France and Fitzgerald Bone, 2005). However, the credibility of claims may be very low (Chimedtseren et al., 2020). For instance, Klopcic et al. (2020) have shown that only $30 \%$ of respondents trust claims. In turn, Bou-Mitri et al. (2020) have concluded that $49.8 \%$ of respondents (especially women) trust claims when buying bread. Yet even despite a belief in the truthfulness of claims, many consumers are still sceptical about them (Benson et al., 2019). As trust in the food system and control, including claims, is a particularly powerful tool for consumers to make food choices (Ding et al., 2015; Strijbos et al., 2016), proper consumer education is essential for increasing confidence in claims.

\section{Willingness to buy}

Research-based evidence reveals that the presence of NHCs positively influences the willingness to buy such labelled products (Kaur et al., 2017). Claims have even been found to have a greater impact on consumers' willingness to purchase 
than price and eco labels (Banovic et al., 2019). Additionally, people are frequently prepared to pay a premium for such products (Ballco et al., 2020; Jurado and Gracia, 2017). Yet, despite Franco-Arellano et al.'s (2018) finding that consumers are more likely to choose products with claims than those without, a number of studies show that the impact of claims on the willingness to buy products may be negative (Bialkova et al., 2016; Stancu et al., 2017), thus leading to a decrease in purchases (Berning et al., 2011; Kiesel and Villas-Boas, 2013). The results of studies showing an encouragement, or lack thereof, to buy claim-bearing products might also depend on the research group (Benson et al., 2019). Therefore, indepth comparative analyses conducted on a large sample of products, especially those perceived as healthy and unhealthy, might broaden the current knowledge about the willingness to pay/buy.

\section{Misleading claims and the halo effect}

The impact of NHCs on consumers may be related to misperceptions about claims and products containing them. This is partly due to issues with taste perception, associated with the erroneous belief that healthy products are often less palatable. Therefore, products with claims may be perceived as healthier than their quality implies (Annunziata et al., 2014; Williams, 2005). This phenomenon is called the halo effect (Ikonen et al., 2020; López-Galán and de-Magistris, 2020). A positive-sounding claim alone creates a positive image of the whole product, regardless of its other characteristics. This is true, for instance, for food labelled "cholesterol-free" (Andrews et al., 1998) and "fat free" (Chandon, 2013), which may improve the perception of such products. Additionally, claims stating that a product does not contain gluten may convey the meaning that it has a better nutritional quality (Asioli et al., 2017; Kaur et al., 2017).

However, the presence of claims may also lead to an increased consumption of unhealthy products. This may particularly affect people willing to eat healthily, who trust health-related information (Wansink and Chandon, 2006). Furthermore, some consumers may misinterpret the occurrence of claims (Aschemann-Witzel and Grunert, 2015; van Buul and Brouns, 2015). This might stem from taste-related issues or consumers' scepticism towards NHCs themselves (Bialkova et al., 2016; Fenko et al., 2016). Ultimately, it is impossible to state unequivocally what the actual impact of NHCs on claim-bearing food and on consumers is (Annunziata and Vecchio, 2013; Hieke et al., 2015). Therefore, this issue requires additional research and in-depth analyses.

\section{Conclusions regarding the content analysis}

The present section has analysed the main topics covered in various articles relating to NHCs. As it is still impossible to draw unequivocal and wholly convincing conclusions about the genuine perception and role of claims, this analysis may constitute the basis for further research on this topic. In particular, there is a lack of extensive longitudinal research focusing on a broad range of products. 
Furthermore, in many countries the level of knowledge or consumer confidence regarding claims is still insufficient. This should encourage not only governments but also food producers to intensify consumer education. Without undertaking such steps, achieving the goal of improving consumers' eating habits, which was set during the marketing of NHCs, may be long and difficult.

\section{Conclusions}

The present paper is an example of a systematic literature review (Paul and Criado, 2020). Its principle asset consists in it being based on the Scopus database, containing most of the magazines and articles which also appear in WoS (Mongeon and Paul-Hus, 2016). The analysis included 196 articles containing the phrase NCs in the title, abstract, or keywords, and 1588 articles with the phrase HCs and 98 with both phrases.

A number of topics are covered in the articles presented in this paper. Among other things, their authors have focused on reconciling the impact of claims on the perception of products considered healthy or unhealthy, on the influence of claims on attention, attitudes, perception, intentions, behaviour, and taste perception. NHCs have also been examined in the context of consumer knowledge and education, demographic data (e.g., age, gender), trust, understanding the meaning of claims, willingness to pay for or buy claim-bearing products, the halo effect, as well as the misleading role of claims and problems with their interpretation.

This study is not devoid of weaknesses, though. The research has been conducted only on the basis of the Scopus database. Despite the possibility of considering additional, comparative analyses using other databases in future research, the current study is highly reliable and gives a fair presentation of the publishing reality of the discussed topic (Mongeon and Paul-Hus, 2016). Therefore, it can be concluded that the strength of this article lies not only in an in-depth analysis of articles containing the investigated keywords, but also in a broad description of topics covered therein. Hence, the article might aid in indicating potential directions for further research on claims, as well as contribute to their better understanding by consumers. This may lead to future improvement of consumers' eating habits and, consequently, to the reduction in civilisation diseases, which were the intentions behind the introduction of NHCs onto the global market. As such, this article can be used both by business practitioners and, above all, by researchers analysing academic papers on NHC-related topics.

Nevertheless, it is still necessary to conduct further research, especially longitudinal or based on a great diversity of food products that differ in terms of their being perceived as healthy/unhealthy. Such analyses might enable a better and more complete examination of the actual predictors of consumer perceptions and attitudes, as well as the impact of statements on consumer intentions or behaviour. What also appears indispensable is the further education of consumers, 
which is likely to increase the understanding of and confidence in nutrition and health claims.

\section{References}

Al-Ani H.H., Devi A., Eyles H., Swinburn B., Vandevijvere S. 2016. Nutrition and health claims on healthy and less-healthy packaged food products in New Zealand. British Journal of Nutrition 116(6): 1087-1094 (https://doi.org/10.1017/S0007114516002981).

Andrews J.C., Netemeyer R.G., Burton S. 1998. Consumer generalization of nutrient content claims in advertising. Journal of Marketing 62(4): 62-75 (https://doi. org/10.2307/1252287).

Annunziata A., Mariani A., Vecchio R., 2014. Consumer understanding and use of health claims for foods. Recent Patents on Food, Nutrition \& Agriculture 6(2): 113-126 (https://doi.org/10.2174/2212798407666150213121543).

Annunziata A., Vecchio R., 2013. Consumer perception of functional foods: A conjoint analysis with probiotics. Food Quality and Preference 28(1): 348-355 (https://doi. org/10.1016/j.foodqual.2012.10.009).

Annunziata A., Vecchio R., Kraus A., 2016. Factors affecting parents' choices of functional foods targeted for children Azzurra. International Journal of Consumer Studies 40(5): 527-535. (https://doi.org/10.1111/ijcs.12297).

Aschemann-Witzel J., Grunert K.G., 2015. Influence of "soft" versus "scientific" health information framing and contradictory information on consumers' health inferences and attitudes towards a food supplement. Food Quality and Preference 42: 90-99 (https://doi.org/10.1016/j.foodqual.2015.01.008).

Aschemann-Witzel J., Hamm U., 2010. Do consumers prefer foods with nutrition and health claims? results of a purchase simulation. Journal of Marketing Communications 16(1-2): 47-58 (https://doi.org/10.1080/13527260903342746).

Asioli D., Aschemann-Witzel J., Caputo V., Vecchio R., Annunziata A., Næs T., Varela P., 2017. Making sense of the "clean label" trends: A review of consumer food choice behavior and discussion of industry implications. Food Research International 99: 58-71 (https://doi.org/10.1016/j.foodres.2017.07.022).

Baglione S.L., Tucci L.A., Stanton J.L., 2012. Self reported nutritional knowledge and the acceptance of health related food benefit claims. British Food Journal 114(4): 453-468 (https://doi.org/10.1108/00070701211219496).

Ballco P., Caputo V., De-Magistris T., 2020. Consumer valuation of European nutritional and health claims: Do taste and attention matter? Food Quality and Preference 79(103793): 1-13 (https://doi.org/10.1016/j.foodqual.2019.103793).

Ballco P., de-Magistris T., Caputo V., 2019. Consumer preferences for nutritional claims: An exploration of attention and choice based on an eye-tracking choice experiment. Food Research International 116: 37-48 (https://doi.org/10.1016/j.foodres.2018.12.031).

Banovic M., Reinders M.J., Claret A., Guerrero L., Krystallis A., 2019. A cross-cultural perspective on impact of health and nutrition claims, country-of-origin and eco-label on consumer choice of new aquaculture products. Food Research International 123: 36-47 (https://doi.org/10.1016/j.foodres.2019.04.031).

Barreiro-Hurlé J., Gracia A., de-Magistris T., 2010. Does nutrition information on food products lead to healthier food choices? Food Policy 35(3): 221-229 (https://doi. org/10.1016/j.foodpol.2009.12.006). 
Bazhan M., Keshavarz-Mohammadi N., Hosseini H., Kalantari N., 2017. Consumers' awareness and perceptions regarding functional dairy products in Iran: A qualitative research. British Food Journal 119(2): 253-266 (https://doi.org/10.1108/BFJ-062016-0270).

Belei N., Geyskens K., Goukens C., Ramanathan S., Lemmink J., 2012. The best of both worlds? Effects of attribute-induced goal conflict on consumption of healthful indulgences. Journal of Marketing Research 49(6): 900-909 (https://doi.org/10.1509/ jmr.10.0155).

Benson T., Lavelle F., McCloat A., Mooney E., Bucher T., Egan B., Dean M., 2019. Are the claims to blame? A qualitative study to understand the effects of nutrition and health claims on perceptions and consumption of food. Nutrients 11(9): 1-14 (https://doi. org/10.3390/nu11092058).

Berning J.P., Chouinard H.H., Mccluskey J.J., 2011. Do positive nutrition shelf labels affect consumer behavior? Findings from a field experiment with scanner data. American Journal of Agricultural Economics 93(2): 364-369 (https://doi.org/10.1093/ajae/ aaq104).

Bialkova S., Grunert K.G., Juhl H.J., Wasowicz-Kirylo G., Stysko-Kunkowska M., van Trijp H.C.M., 2014. Attention mediates the effect of nutrition label information on consumers' choice: Evidence from a choice experiment involving eye-tracking. Appetite 76: 66-75 (https://doi.org/10.1016/j.appet.2013.11.021).

Bialkova S., Sasse L., Fenko A., 2016. The role of nutrition labels and advertising claims in altering consumers' evaluation and choice. Appetite 96: 38-46 (https://doi. org/10.1016/j.appet.2015.08.030).

Bimbo F., Bonanno A., Nocella G., Viscecchia R., Nardone G., De Devitiis B., Carlucci D., 2017. Consumers' acceptance and preferences for nutrition-modified and functional dairy products: A systematic review. Appetite 113: 141-154 (https://doi.org/10.1016/j. appet.2017.02.031).

Bitzios M., Fraser I., Haddock-Fraser J., 2011. Functional ingredients and food choice: Results from a dual-mode study employing means-end-chain analysis and a choice experiment. Food Policy 36(5): 715-725 (https://doi.org/10.1016/j.foodpol.2011.06.004).

Bou-Mitri C., Khnaisser L., Bou Ghanem M., Merhi S., Fares J.E.H., Doumit J., Farhat A.G., 2020. Consumers' exposure to claims on pre-packed bread: the case of a developing country, Lebanon. Nutrition and Food Science 50(6): 1033-1051 (https://doi. org/10.1108/NFS-08-2019-0273).

Bower J.A., Saadat M.A., Whitten C. 2003. Effect of liking, information and consumer characteristics on purchase intention and willingness to pay more for a fat spread with a proven health benefit. Food Quality and Preference 14(1): 65-74 (https://doi. org/10.1016/S0950-3293(02)00019-8).

Bryla P., 2020. Who reads food labels? Selected predictors of consumer interest in frontof-package and back-of-package labels during and after the purchase. Nutrients 12(9): 2605.

Campos S., Doxey J., Hammond D., 2011. Nutrition labels on pre-packaged foods: A systematic review. Public Health Nutrition 14(8): 1496-1506 (https://doi.org/10.1017/ S1368980010003290).

Carrillo E., Fiszman S., Lähteenmäki L., Varela P., 2014. Consumers' perception of symbols and health claims as health-related label messages. A cross-cultural study. Food Research International 62: 653-661 (https://doi.org/10.1016/j.foodres.2014.04.028).

Cavaliere A., Ricci E.C., Banterle A., 2015. Nutrition and health claims: Who is interested? An empirical analysis of consumer preferences in Italy. Food Quality and Preference 41: 44-51 (https://doi.org/10.1016/j.foodqual.2014.11.002). 
Chandon P., 2013. How package design and packaged-based marketing claims lead to overeating. Applied Economic Perspectives and Policy 35(1): 7-31 (https://doi. org/10.1093/aepp/pps028).

Chimedtseren N., Kelly B., McMahon A.T., Yeatman H., 2020. Prevalence and credibility of nutrition and health claims: Policy implications from a case study of mongolian food labels. International Journal of Environmental Research and Public Health 17(20): 1-19 (https://doi.org/10.3390/ijerph17207456).

Choi H., Paek H.J., King K.W., 2012. Are nutrient-content claims always effective? matchup effects between product type and claim type in food advertising. International Journal of Advertising 31(3): 421-443 (https://doi.org/10.2501/IJA-31-2-421-443).

Choi H., Reid L.N., 2018. Promoting Healthy Menu Choices in Fast Food Restaurant Advertising: Influence of Perceived Brand Healthiness, Brand Commitment, and Health Consciousness. Journal of Health Communication 23(4): 387-398 (https://doi.org/10 $.1080 / 10810730.2018 .1455769)$.

Colby S.E., Johnson L.A., Scheett A., Hoverson B., 2010. Nutrition Marketing on Food Labels. Journal of Nutrition Education and Behavior 42(2): 92-98 (https://doi. org/10.1016/j.jneb.2008.11.002).

Contini C., Casini L., Stefan V., Romano C., Juhl H.J., Lähteenmäki L., Scozzafava G., Grunert K.G., 2015. Some like it healthy: Can socio-demographic characteristics serve as predictors for a healthy food choice? Food Quality and Preference 46: 103-112 (https://doi.org/10.1016/j.foodqual.2015.07.009).

Cornish L.S., 2012. Perceived trustworthiness of online shops. Journal of Consumer Behaviour 11: 392-302 (https://doi.org/10.1002/cb).

Cowburn G., Stockley L., 2005. Consumer understanding and use of nutrition labelling: a systematic review. Public Health Nutrition 8(1): 21-28 (https://doi.org/10.1079/ phn2004666).

de Boer A., Bast A., 2015. International legislation on nutrition and health claims. Food Policy 55: 61-70 (https://doi.org/10.1016/j.foodpol.2015.06.002).

de Sousa L.M.L., Stangarlin-Fiori L., Costa E.H.S., Furtado F., Medeiros C.O., 2020. Use of nutritional food labels and consumers' confidence in label information. Revista de Nutricao 33: 1-18 (https://doi.org/10.1590/1678-9865202033E190199).

Dean M., Lampila P., Shepherd R., Arvola A., Saba A., Vassallo M., Claupein E., Winkelmann M., Lähteenmäki L., 2012. Perceived relevance and foods with health-related claims. Food Quality and Preference 24(1): 129-135 (https://doi.org/10.1016/j.foodqual.2011.10.006).

Ding Y., Veeman M.M., Adamowicz W.L., 2015. Functional food choices: Impacts of trust and health control beliefs on Canadian consumers' choices of canola oil. Food Policy 52: 92-98 (https://doi.org/10.1016/j.foodpol.2014.12.002).

Drichoutis A., Lazaridis P., Nayga Jr. R., 2006. Consumers' use of nutritional labels: a review of research studies and issues. Academy of Marketing Science Review 1.

Duffy E.W., Hall M.G., Dillman Carpentier F.R., Musicus A.A., Meyer M.L., Rimm E., Smith Taillie L., 2021. Nutrition Claims on Fruit Drinks Are Inconsistent Indicators of Nutritional Profile: A Content Analysis of Fruit Drinks Purchased by Households With Young Children. Journal of the Academy of Nutrition and Dietetics 121(1): 3646.e4 (https://doi.org/10.1016/j.jand.2020.08.009).

Egnell M., Talati Z., Hercberg S., Pettigrew S., Julia C., 2018. Objective understanding of front-of-package nutrition labels: An international comparative experimental study across 12 countries. Nutrients 10(10) (https://doi.org/10.3390/nu10101542). 
Elliott C., 2019. Tracking kids' food: Comparing the nutritional value and marketing appeals of child-targeted supermarket products over time. Nutrients 11(8): 1-16 (https:// doi.org/10.3390/nu11081850).

FAO, World Health Organization, 1998. Vitamin and mineral requirements in human nutrition. Second edition. World Health Organization.

Fenko A., Kersten L., Bialkova S., 2016. Overcoming consumer scepticism toward food labels: The role of multisensory experience. Food Quality and Preference 48: 81-92 (https://doi.org/10.1016/j.foodqual.2015.08.013).

Food and Agriculture Organization of the United Nations, 2012Codex guideline for use of nutrition and health claims - CAC/GL 23-1997. In Guidelines for use of nutrition and health claims (http://www.fao.org/ag/humannutrition/32444-09f5545b8abe9a0c3baf01a4502ac36e4.pdf; access: 24.11.2021).

Franco-Arellano B., Labonté M.È., Bernstein J.T., L’Abbé M.R., 2018. Examining the nutritional quality of Canadian packaged foods and beverages with and without nutrition claims. Nutrients 10(7): 9-11 (https://doi.org/10.3390/nu10070832).

Giacalone D., Jaeger S.R., 2016. Better the devil you know? How product familiarity affects usage versatility of foods and beverages. Journal of Economic Psychology 55: 120-138 (https://doi.org/10.1016/j.joep.2016.02.005).

Ginon E., Lohéac Y., Martin C., Combris P., Issanchou S., 2009. Effect of fibre information on consumer willingness to pay for French baguettes. Food Quality and Preference 20(5): 343-352 (https://doi.org/10.1016/j.foodqual.2009.01.002).

Gravel K., Doucet É., Peter Herman C., Pomerleau S., Bourlaud A.S., Provencher V., 2012. "Healthy," "diet," or "hedonic". How nutrition claims affect food-related perceptions and intake? Appetite 59(3): 877-884 (https://doi.org/10.1016/j.appet.2012.08.028).

Grunert K.G., Fernández-Celemín L., Wills J.M., Bonsmann S.S.G., Nureeva L., 2010. Use and understanding of nutrition information on food labels in six European countries. Journal of Public Health 18(3): 261-277 (https://doi.org/10.1007/s10389-009-0307$0)$.

Grunert K.G., Wills J.M., Fernández-Celemín L., 2010. Nutrition knowledge, and use and understanding of nutrition information on food labels among consumers in the UK. Appetite 55(2): 177-189 (https://doi.org/10.1016/j.appet.2010.05.045).

Hamilton J., Knox B., Hill D., Parr H., 2008. Reduced fat products - Consumer perceptions and preferences. British Food Journal 102(7): 494-506.

Hassan H.F., Dimassi H., 2020. Usage and Understanding of Food Labels among Lebanese Shoppers Abstract. International Journal of Consumer Studies 41(5): 570-575.

Hawley K.L., Roberto C.A., Bragg M.A., Liu P.J., Schwartz M.B., Brownell K.D., 2013. The science on front-of-package food labels. Public Health Nutrition 16(3): 430-439 (https://doi.org/10.1017/S1368980012000754).

Hieke S., Cascanette T., Pravst I., Kaur A., Van Trijp H., Verbeke W., Grunert K.G., 2016. The role of health-related claims and symbols in consumer behaviour: The CLYMBOL project. Agro Food Industry Hi-Tech 27(3): 26-29.

Hieke S., Kuljanic N., Pravst I., Miklavec K., Kaur A., Brown K.A., Egan B.M., Pfeifer K., Gracia A., Rayner M., 2016. Prevalence of nutrition and health-related claims on pre-packaged foods: A five-country study in europe. Nutrients 8(3) (https://doi. org/10.3390/nu8030137).

Hieke S., Kuljanic N., Wills J.M., Pravst I., Kaur A., Raats M.M., van Trijp H.C.M., Verbeke W., Grunert K.G., 2015. The role of health-related claims and health-related symbols in consumer behaviour: Design and conceptual framework of the CLYMBOL project and initial results. Nutrition Bulletin 40(1): 66-72 (https://doi.org/10.1111/ nbu.12128). 
Hill J.O., Wyatt H.R., Reed G.W., Peters J.C., 2003. Obesity and the environment: Where do we go from here? Science 299(5608): 853-855 (https://doi.org/10.1126/ science.1079857).

Hoppert K., Mai R., Zahn S., Schwarz P.E.H., Hoffmann S., Rohm H., 2014. Is there a fit in cognitive and sensory evaluation of yogurt? The moderating role of nutrition training. Food Quality and Preference 31(1): 65-68 (https://doi.org/10.1016/j.foodqual.2013.08.001).

Ikonen I., Sotgiu F., Aydinli A., Verlegh P.W.J., 2020. Consumer effects of front-of-package nutrition labeling: an interdisciplinary meta-analysis. Journal of the Academy of Marketing Science 48(3): 360-383 (https://doi.org/10.1007/s11747-019-00663-9).

Jurado F., Gracia A., 2017. Does the valuation of nutritional claims differ among consumers? Insights from Spain. Nutrients 9(2): 1-15 (https://doi.org/10.3390/nu9020132).

Kaur A., Scarborough P., Hieke S., Kusar A., Pravst I., Raats M., Rayner M., 2016. Corrigendum: The nutritional quality of foods carrying health-related claims in Germany, The Netherlands, Spain, Slovenia and the United Kingdom. European Journal of Clinical Nutrition 70: 1388-1395 (https://doi.org/10.1038/ejcn.2016.114).

Kaur A., Scarborough P., Rayner M., 2017. A systematic review, and meta-analyses, of the impact of health-related claims on dietary choices. International Journal of Behavioral Nutrition and Physical Activity 14(1): 1-17 (https://doi.org/10.1186/s12966-0170548-1).

Kiesel K., Villas-Boas S.B., 2013. Can information costs affect consumer choice? Nutritional labels in a supermarket experiment. International Journal of Industrial Organization 31(2): 153-163 (https://doi.org/10.1016/j.ijindorg.2010.11.002).

Klopčič M., Slokan P., Erjavec K., 2020). Consumer preference for nutrition and health claims: A multi-methodological approach. Food Quality and Preference 82(103863) (https://doi.org/10.1016/j.foodqual.2019.103863).

Kourouniotis S., Keast R.S.J., Riddell L.J., Lacy K., Thorpe M.G., Cicerale S., 2016. The importance of taste on dietary choice, behaviour and intake in a group of young adults. Appetite 103: 1-7 (https://doi.org/10.1016/j.appet.2016.03.015).

Kowalkowska J., Lonnie M., Wadolowska L., Czarnocinska J., Jezewska-Zychowicz M., Babicz-Zielinska E., 2018. Health-and taste-related attitudes associated with dietary patterns in a representative sample of Polish girls and young women: A cross-sectional study (GEBaHealth project). Nutrients 10(254): 1-18 (https://doi.org/10.3390/ nu10020254).

Kreuter M.W., Brennan L.K., Scharff D.P., Lukwago S.N., 1997. Do nutrition label readers eat healthier diets? Behavioral correlates of adults' use of food labels. American Journal of Preventive Medicine 13(4): 277-283 (https://doi.org/10.1016/s07493797(18)30175-2).

Krutulyte R., Grunert K.G., Scholderer J., Lähteenmäki L., Hagemann K.S., Elgaard P., Nielsen B., Graverholt J.P., 2011. Perceived fit of different combinations of carriers and functional ingredients and its effect on purchase intention. Food Quality and Preference 22(1): 11-16 (https://doi.org/10.1016/j.foodqual.2010.06.001).

Krystallis A., Maglaras G., Mamalis S., 2008. Motivations and cognitive structures of consumers in their purchasing of functional foods. Food Quality and Preference 19(6): 525-538 (https://doi.org/10.1016/j.foodqual.2007.12.005).

Lähteenmäki L., 2013. Claiming health in food products. Food Quality and Preference 27(2): 196-201 (https://doi.org/10.1016/j.foodqual.2012.03.006).

Lähteenmäki L., Lampila P., Grunert K., Boztug Y., Ueland $\varnothing$., Åström A., Martinsdóttir E., 2010. Impact of health-related claims on the perception of other product attributes. Food Policy 35(3): 230-239 (https://doi.org/10.1016/j.foodpol.2009.12.007). 
Lalor F., Madden C., McKenzie K., Wall P.G., 2011. Health claims on foodstuffs: A focus group study of consumer attitudes. Journal of Functional Foods 3(1): 56-59 (https:// doi.org/10.1016/j.jff.2011.02.001).

Lampila P., van Lieshout M., Gremmen B., Lähteenmäki L., 2009. Consumer attitudes towards enhanced flavonoid content in fruit. Food Research International 42(1): 122129 (https://doi.org/10.1016/j.foodres.2008.09.002).

Larkin D., Martin C.R., 2016. Caloric estimation of healthy and unhealthy foods in normal-weight, overweight and obese participants. Eating Behaviors 23: 91-96 (https:// doi.org/10.1016/j.eatbeh.2016.08.004).

López-Galán B., de-Magistris T., 2020. Personal and Psychological Traits Influencing the Willingness to Pay for Food with Nutritional Claims: A Comparison between Vice and Virtue Food Products. Foods 9(6): 733 (https://doi.org/10.3390/foods9060733).

Malloy-Weir L., Cooper M., 2017. Health literacy, literacy, numeracy and nutrition label understanding and use: a scoping review of the literature. Journal of Human Nutrition and Dietetics 30(3): 309-325 (https://doi.org/10.1111/jhn.12428).

Maubach N., Hoek J., Mather D., 2014. Interpretive front-of-pack nutrition labels. Comparing competing recommendations. Appetite 82: 67-77 (https://doi.org/10.1016/j. appet.2014.07.006).

Meyerding S.G.H., Merz N., 2018. Consumer preferences for organic labels in Germany using the example of apples - Combining choice-based conjoint analysis and eye-tracking measurements. Journal of Cleaner Production 181: 772-783 (https://doi. org/10.1016/j.jclepro.2018.01.235).

Miklavec K., Pravst I., Grunert K.G., Klopčič M., Pohar J., 2015. The influence of health claims and nutritional composition on consumers' yoghurt preferences. Food Quality and Preference 43: 26-33 (https://doi.org/10.1016/j.foodqual.2015.02.006).

Mongeon P., Paul-Hus A., 2016. The journal coverage of Web of Science and Scopus: a comparative analysis. Scientometrics 106(1): 213-228 (https://doi.org/10.1007/ s11192-015-1765-5).

Murniece I., Straumite E., 2014. The information presented on labels for bread produced in Latvia. Food Chemistry 162: 117-121 (https://doi.org/10.1016/j.foodchem.2014.04.048).

Oliveira D., Ares G., Deliza R., 2018. The effect of health/hedonic claims on consumer hedonic and sensory perception of sugar reduction: Case study with orange/passionfruit nectars. Food Research International 108: 111-118 (https://doi.org/10.1016/j. foodres.2018.03.003).

Oliveira D., Machín L., Deliza R., Rosenthal A., Walter E.H., Giménez A., Ares G., 2016. Consumers' attention to functional food labels: Insights from eye-tracking and change detection in a case study with probiotic milk. LWT - Food Science and Technology 68: 160-167 (https://doi.org/10.1016/j.lwt.2015.11.066).

Oostenbach L.H., Slits E., Robinson E., Sacks G., 2019. Systematic review of the impact of nutrition claims related to fat, sugar and energy content on food choices and energy intake. BMC Public Health 19(1): 1296 (https://doi.org/10.1186/s12889-019-7622-3).

Orquin J.L., Scholderer J., 2015. Consumer judgments of explicit and implied health claims on foods: Misguided but not misled. Food Policy 51: 144-157 (https://doi. org/10.1016/j.foodpol.2015.01.001).

Paul J., Criado A.R., 2020. The art of writing literature review: What do we know and what do we need to know? International Business Review 29(4): 101717 (https://doi. org/10.1016/j.ibusrev.2020.101717). 
Persoskie A., Hennessy E., Nelson W.L., 2017US Consumers' Understanding of Nutrition Labels in 2013: The Importance of Health Literacy. Preventing Chronic Disease 14: E86 (https://doi.org/10.5888/pcd14.170066).

Peschel A.O., Orquin J.L., Mueller Loose S., 2019. Increasing consumers' attention capture and food choice through bottom-up effects. Appetite 132: 1-7 (https://doi. org/10.1016/j.appet.2018.09.015).

Provencher V., Jacob R., 2016. Impact of Perceived Healthiness of Food on Food Choices and Intake. Current Obesity Reports 5(1): 65-71 (https://doi.org/10.1007/s13679016-0192-0).

Pulker C.E., Scott J.A., Pollard C.M., 2018. Ultra-processed family foods in Australia: Nutrition claims, health claims and marketing techniques. Public Health Nutrition 21(1): 38-48 (https://doi.org/10.1017/S1368980017001148).

Raghunathan R., Naylor R.W., Hoyer W.D., 2006. The unhealthy = Tasty intuition and its effects on taste inferences, enjoyment, and choice of food products. Journal of Marketing 70(4): 170-184 (https://doi.org/10.1509/jmkg.70.4.170).

Roseman M.G., Joung H.W., Littlejohn E.I., 2018. Attitude and Behavior Factors Associated with Front-of-Package Label Use with Label Users Making Accurate Product Nutrition Assessments. Journal of the Academy of Nutrition and Dietetics 118(5): 904-912 (https://doi.org/10.1016/j.jand.2017.09.006).

Russo France K., Fitzgerald Bone P., 2005. Policy makers' paradigms and evidence from consumer interpretations of dietary supplement labels. Journal of Consumer Affairs 39(1): 27-51 (https://doi.org/10.1111/j.1745-6606.2005.00002.x).

Sajdakowska M., Gębski J., Żakowska-Biemans S., Jeżewska-Zychowicz M., 2019. Willingness to eat bread with health benefits: habits, taste and health in bread choice. Public Health 167: 78-87 (https://doi.org/10.1016/j.puhe.2018.10.018).

Samant S.S., Seo H.S., 2016. Effects of label understanding level on consumers' visual attention toward sustainability and process-related label claims found on chicken meat products. Food Quality and Preference 50: 48-56 (https://doi.org/10.1016/j. foodqual.2016.01.002).

Sandmann A., Brown J., Mau G., Saur M., Amling M., Barvencik F., 2015. Acceptance of vitamin D-fortified products in Germany - A representative consumer survey. Food Quality and Preference 43: 53-62 (https://doi.org/10.1016/j.foodqual.2015.02.011).

Siegrist M., Shi J., Giusto A., Hartmann C., 2015. Worlds apart. Consumer acceptance of functional foods and beverages in Germany and China. Appetite 92: 87-93 (https:// doi.org/10.1016/j.appet.2015.05.017).

Stancu V., Grunert K.G., Lähteenmäki L., 2017. Consumer inferences from different versions of a beta-glucans health claim. Food Quality and Preference 60: 81-85 (https:// doi.org/10.1016/j.foodqual.2017.03.001).

Steinhauser J., Hamm U., 2018. Consumer and product-specific characteristics influencing the effect of nutrition, health and risk reduction claims on preferences and purchase behavior - A systematic review. Appetite 127: 303-323 (https://doi.org/10.1016/j.appet.2018.05.012).

Steinhauser J., Janssen M., Hamm U., 2019. Who buys products with nutrition and health claims? A purchase simulation with eye tracking on the influence of consumers' nutrition knowledge and health motivation. Nutrients 11(9): 2199 (https://doi. org/10.3390/nu11092199).

Strijbos C., Schluck M., Bisschop J., Bui T., de Jong I., van Leeuwen M., von Tottleben M., van Breda S.G., 2016Consumer awareness and credibility factors of health claims on innovative meat products in a cross-sectional population study in the Netherlands. Food Quality and Preference 54: 13-22 (https://doi.org/10.1016/j.foodqual.2016.06.014). 
Suzuki S., Park J., 2018Consumer evaluation of healthy, unpleasant-tasting food and the post-taste effect of positive information. Food Quality and Preference 66: 107-110 (https://doi.org/10.1016/j.foodqual.2018.01.006).

Talati Z., Pettigrew S., Hughes C., Dixon H., Kelly B., Ball K., Miller C., 2016. The combined effect of front-of-pack nutrition labels and health claims on consumers' evaluation of food products. Food Quality and Preference 53: 57-65 (https://doi.org/10.1016/j. foodqual.2016.05.016).

Thorndike A.N., Sonnenberg L., Riis J., Barraclough S., Levy D.E., 2012. A 2-phase labeling and choice architecture intervention to improve healthy food and beverage choices. American Journal of Public Health 102(3): 527-533 (https://doi.org/10.2105/ AJPH.2011.300391).

Tugault-Lafleur C.N., Black J.L., 2019. Differences in the quantity and types of foods and beverages consumed by Canadians between 2004 and 2015. Nutrients 11(3): 526 (https://doi.org/10.3390/nu11030526).

Turnwald B.P., Jurafsky D., Conner A., Crum A.J., 2017. Reading between the menu lines: Are restaurants' descriptions of "healthy" foods unappealing? Health Psychology 36(11): 1034-1037 (https://doi.org/10.1037/hea0000501).

United States Government Accountability Office, 2012. Food labeling: FDA needs to reassess its approach to protecting consumers from false or misleading claims (https:// www.gao.gov/assets/320/314473.pdf; access: 24.11.2021).

Urala N., 2005. Functional foods in Finland costumers' views, attitudes and willingness to use. VTT Technical Research Centre of Finland.

Urala N., Lähteenmäki L., 2007. Consumers' changing attitudes towards functional foods. Food Quality and Preference 18(1): 1-12 (https://doi.org/10.1016/j.foodqual.2005.06.007).

van Buul V.J., Brouns F.J.P.H., 2015. Nutrition and Health Claims as Marketing Tools. Critical Reviews in Food Science and Nutrition 55(11): 1552-1560 (https://doi.org/10 .1080/10408398.2012.754738).

Vecchio R., Cavallo C., 2019. Increasing healthy food choices through nudges: A systematic review. Food Quality and Preference 78: 103714 (https://doi.org/10.1016/j. foodqual.2019.05.014).

Wansink B., Chandon P., 2006. Can "low-fat" nutrition labels lead to obesity? Journal of Marketing Research 43(4): 605-617 (https://doi.org/10.1509/jmkr.43.4.605).

Williams P., 2005. Consumer understanding and use of health claims for foods. Nutrition Reviews 63(7): 256-264 (https://doi.org/10.1301/nr.2005.jul.256-264).

Zaheer H., Breyer Y., Dumay J., 2019. Digital entrepreneurship: An interdisciplinary structured literature review and research agenda. Technological Forecasting and Social Change 148: 119735 (https://doi.org/10.1016/j.techfore.2019.119735). 


\title{
Sylwia Majcher
}

\section{Consumer attitudes to health and nutrition claims}

\begin{abstract}
Purpose: To examine the impact of nutrition and health claims on Polish consumers' buying attitudes and intentions.

Design/methodology/approach: The study was conducted on a group of 200 Polish consumers using the CAWI method. The selection of the sample was deliberate and used the "snowball effect". Elements of experimental measurement were used in the study. The survey form consisted of 4 parts: A - the evaluation of photos of sample products with nutrition claims, health claims, both type of claims or with no claims (control group); B - answering questions about food labelling and the use of nutrition claims; $\mathrm{C}$ - the expression of opinions on health and nutrition claims presented as separate, non-product-specific messages. In Part A, respondents were divided into 4 equivalent groups that evaluated products with different combinations of claim types.

Findings: The perception of the health and nutritional quality of products with health and nutrition claims is strongly dependent on the consumer's attitude towards a given type of food. The presence of claims seems to have a neutral effect on the perception of the taste of products associated with healthy eating, but a negative one in the case of products considered unhealthy. Despite great interest in the information contained on the labels of food products and healthy eating, Polish consumers still show a low level of knowledge about claims. At the same time, they seem to be sceptical of the reliability of the health and nutrition-related information on the packaging of food products, which is not correlated with their level of knowledge on the subject. The presence of claims is not decisive for consumers in terms of making a purchasing decision, and claims are less important to them than the use-by-date or the price of the product. Claims also do not entail that consumers perceive products as having less caloric content.

Practical implications: In order to meet the expectations of modern consumers, food producers should consider placing both types of claims on labels, and engage in other promotional activities that will draw consumers' attention to the health and nutritional benefits of their products. Due to the fact that a high level of knowledge and interest in healthy eating does not translate into a better knowledge of claims, it is necessary to increase consumers' awareness of food law. Due to consumer scepticism about health and nutritional-related information, food producers should ensure that the information on their product labels is as consistent as possible. There is a need for more research focused on identifying the factors that limit the correct interpretation of claims that are beneficial for consumers' food choices.
\end{abstract}


Originality and value: This is one of the few studies conducted on Polish food consumers which examine how the presence of health and nutrition claims on food labels affect the perception and purchase intentions of food products. Thanks to the use of various forms of questions in the survey form, it was possible not only to get to know the opinions of consumers on the use of claims and food labelling, but also to check their knowledge in this area in an objective way.

Keywords: health claims, nutrition claims, consumer behaviour, food products

\section{Introduction}

The attitudes and behaviours of food consumers have changed significantly over the last dozen or so years. This includes healthy eating trends and increasing interest in the influence of nutrients on general health, as well as the prevention and treatment of existing diseases. In the face of these changes, foods with potentially beneficial effects on health and weight control have become more common (de Boer, 2021, p. 2).

The information on food packaging can encourage consumers to make healthier food choices, facilitate the tailoring of portions to their actual nutritional needs, or support their education in healthy eating. Unfortunately, it is difficult to reap such benefits if the food market is saturated with the a great variety of food products and if an abundance of information is contained on their labels. As a result, consumers focus their attention on simple messages that will help them find a product that stands out for its health or nutritional values, such as health and nutrition claims. Such an approach may unfortunately lead them to make the wrong purchasing decisions. Claims are increasingly used to increase the purchase attractiveness of a product by food producers, who in many cases do not act honestly and mislead consumers (Davidović et al., 2021, 1-2).

Ensuring that consumers can safely use the information on food packaging is particularly important in the face of increasing obesity rates, as is verifying that this information is of the highest quality and complies with existing standards. By creating a friendly environment for consumers to make the right food choices, the epidemic of obesity and related diseases can be counteracted, and claims and other information on food packaging are a key element in this regard. For most consumers, they are the primary source of nutritional knowledge. Their role should be primarily to raise consumers' awareness of the composition and properties of food products, and thus encourage their interest in healthy foods. In practice, however, buyers do not use them sufficiently, due to difficulties in understanding them and the limited amount of time to make purchasing decisions (Oostenbach et al., 2019, p. 2).

The impact of nutrition claims on consumers' purchasing intentions and dietary choices has been the subject of research by many authors (Steinhauser et al., 2019, pp. 4-14; Steinhauser and Hamm, 2018, pp. 1-33; Lynam et al., 2011, pp. 2-6; Annunziata and Mariani, 2019, pp. 3-13). However, there are few works in which conclusions about attitudes and behaviours towards participants' 
statements are juxtaposed with their objectively verified knowledge about this form of marketing communication. There is also a lack of studies that would compare how consumers' perception of claims differs depending on whether they are placed on a product or are separate information.

Therefore, the main purposes of this work are:

1. To identify factors associated with food consumers and producers that determine the effective influencing of claims on the perception of food products bearing them.

2. To identify factors that negatively affect purchase intentions regarding claim-bearing products.

3. To determine how claims affect consumers' perception of products.

4. To check whether there is a correlation between consumers' knowledge of the claims and their attitude towards them.

5. To understand the determinants that will effectively encourage consumers to make healthier food choices through claims.

\section{The use of health and nutrition claims in the light of European food law}

Health claims describe or indicate the health-promoting effects of a given product or its ingredients. In turn, a nutrition claim is defined as any claim made on the label of a food product that relates to its nutritional value. The content of both health and nutrition claims must be understandable and transparent to consumers so that their interpretation is identical to their real meaning. The condition for making claims in accordance with European Food Law is that they must not imply that other foods are less healthy or less nutritious. It is also forbidden to use claims that seek to convince consumers that the consumption of a given product is necessary to cover all the necessary nutrients. It is important that the regulations concerning claims also apply to symbols, trademarks or even product names, which should be supplemented by permitted statements (de Boer, 2021, p. 3). In addition, claims are not only health or nutritional messages placed on food packaging, but also those used in marketing campaigns and other promotional activities (O.J. UE, L 404, 30.12.2006, p. 9).

Food law regulations regarding claims may vary depending on the laws and regulations issued in a given country. However, in the case of countries belonging to a given community, e.g. the European Union (EU), they must meet certain standards and requirements in order for the law to be unified. These conditions are primarily used to protect the health of consumers, as well as to minimize the situation of misleading them by dishonest actions of producers (Szymura, 2012, pp. 1-3). The European Union has undertaken to achieve these objectives by issuing Regulation (EC) No 1924/2006 on nutrition and health claims (O.J. UE, L 404, 30.12.2006). However, in 2008 the EU issued Regulation (EC) No 107/2008 of the European Parliament and of the Council amending Regulation (EC) No $1924 / 2006$ on nutrition and health claims made on foods as regards the implementing powers conferred on the Commission (OJ L 39, 13.2.2008, p. 8-10). In 
Europe, in addition to the regulations contained in this regulation, validation of claims by the European Food Safety Authority (EFSA) is mandatory. Any claim that a given food producer wants to put on his product must indicate nutritional or health properties, which are supported by generally accepted, reliable scientific evidence (Szymecka-Wesolowska, 2011, pp. 21-22). Claims that pass the EFSA verification are included in the publicly available list of approved claims. Currently, 30 nutrition claims, which are listed in Regulation (EC) No. 1924/2006, are allowed on the food market. Any nutrition claim that a manufacturer wants to include on the packaging of his product must have the same verbal meaning as any of the claims contained in the regulation and must meet the relevant nutritional criteria. For example, a product can be labelled "source of protein" or a statement with the same wording may be used on its label only if at least $12 \%$ of its energy value comes from protein. In addition to indicating the source of the nutrient, nutrition claims can be formulated using the words (O.J. EU, L 404, 30.12.2006, pp. 9-25):

- Low/very low content/value...;

- High in...;

- Without, without additive, there is no, no contains...;

- Contains...;

- With increased/reduced content...;

- Light;

- Natural/naturally...;

Moving on to health claims, 4 main types can be distinguished (de Boer, 2021, p. 5):

- Functional claims based on generally accepted scientific evidence;

- Functional claims based on newly developed scientific insights;

- Claims relating to the reduction of the risk factor in the development of the disease;

- Statements relating to the growth and development of children.

Although there are only 4 types of these claims, the number of claims that currently exist on the food market is 265. Examples of health claims include: Zinc helps to maintain a proper acid-base balance or magnesium contributes to the maintenance of proper energy metabolism (O. J. EU, L 136, 25.05.2012, pp. 4-40).

The conditions of use and the system for validating claims were checked during the European Commission's Regulatory Fitness and Performance Program (REFIT) from 2013 to 2020. One of the results of REFIT was that health and nutrition claims currently do not fully perform their role and new regulations are needed to take into account the problems identified (de Boer, 2021, p. 2). In addition, there are frequent cases of fraud involving use of statements that are inconsistent with the actual nutritional value or health properties of the product (Lorenzoni et al., 2019, pp. 3-12). 


\section{Food consumers' understanding of claims and their response to them}

A study conducted on a group of 100 participants from five European countries - Germany, the Netherlands, Spain, Slovenia and the United Kingdom - examined whether and how food consumers understand selected health and nutrition claims. Out of these 100 participants, 51\% declared that they use statements quite often or very often on a daily basis. Distinguishing between claims in terms of their types and meaning was not a problem for most participants of this study. The exceptions were statements with difficult vocabulary, such as, for example, one concerning homocysteine metabolism. Difficulties in understanding the statements also appeared when they referred to nutrients not very well known to participants or which were not very common. Nutrition claims were rated more positively for affordability, but at the same time the respondents believed that they should be supplemented with information on the health benefits of consuming the product. In addition, respondents expressed scepticism about nutrition claims indicating that the product is a meal replacement and those with reduced sugar and fat content. The statements were also considered by some respondents as marketing tricks urging them to make larger purchases. The correct interpretation and positive perception of the claims in this study also depended on whether they related to health benefits or nutritional values that were important to the participants. An important result of this work is also the fact that in several cases respondents overinterpreted the statements by assigning them meanings that they did not objectively indicate (Hodgkins et al., 2019, pp. 7-24).

In another paper - a systematic review and meta-analysis of studies conducted in 2014-2017, the impact of food labelling on food purchases, consumer health and the activities of producers was verified. The overall conclusion of this publication is that food labelling has a beneficial effect in protecting the health of consumers. Food labels have been shown to reduce fat consumption and the overall energy value of the diet. In addition, they encourage more frequent consumption of vegetables. However, they still do not affect the consumption of salt, carbohydrates, protein, saturated fats, fruits or whole grains (Shangguan et al., 2019, pp. 7-10).

However, there are also papers whose results indicate that claims induce consumers to consume excessively. This may be the case for individual nutrients when consumers mistakenly believe that the more they consume, the better for their health or are unaware that they are already consuming the ingredient in excess. It also happens that statements are not precise, which leads to them being misunderstood. This is so, for example, in the case of the statement "provides energy", which only states that the product is not calorie-free (and often that it is high-calorie), but for some consumers this message may mean that the consumption of the product will have a stimulating effect on them (Chandon and Wansink, 2012, p. 8).

Misinterpretation is also common in the case of claims regarding the content of a particular nutrient. This is mainly the case when the consumer judges the product based on the claim itself without analysing the nutritional table or ingredient list. This is a particularly harmful approach, as the claims only draw 
attention to healthy ingredients, thereby diverting it from those that are dangerous to health. The same is true when the claim concerns the reduction of the risk of disease by consuming a particular product, while this product also contains ingredients that increase this risk. An equally important problem for consumers is the so-called "Halo effect", which in relation to products with claims refers to the phenomenon of attributing to them qualities that they do not have. However, there is no doubt that not only consumers are to blame, but also producers who are fully aware of the presence and operation of these mechanisms (Talati et al., 2017, p. 2).

\section{Awareness and perception of claims among consumers on the basis of the author's own research}

In the period from 20.04.2021 to 04.05.2021, the author carried out a questionnaire survey with elements of experimental measurement. The study used the CAWI method using Google's web forms. The selection of the sample was deliberate and was performed using the "snowball" effect.

The sample consisted of 200 respondents of Polish nationality. The individual characteristics of respondents are presented in Table 1.

In the first questions of the survey, participants rated the food product presented to them in the pictures, which contained various configurations of claims on their packaging. This part of the form was the only one that differed for individual participants. By sending the appropriate versions of the form, the respondents were divided into 4 groups of 50 people. Group 1 received a form with pictures of products bearing nutrition claims, group 2 with health claims, group 3 with both types of claims, and group 4 with pictures of products without claims. The other packaging elements of the products presented in the pictures for all groups were identical and did not contain any advertising slogans, trademarks or names of manufacturers.

The evaluation criteria were:

- Health;

- Caloric value;

- Taste;

- The reliability of the information on the label;

- Willingness to purchase;

- Willingness to consume.

The rating scale was from 1 to 5 . The ratings in each group were added up and then the average was drawn from them.

The next questions concerned the degree of interest in healthy eating and the information on food labels, as well as the respondents' level of practical and theoretical knowledge regarding claims. Thanks to this, it was possible to get to know the level of knowledge of food law among the respondents, as well as to check how it translates into the ability to use claims. 
Table 1. Individual characteristics of respondents

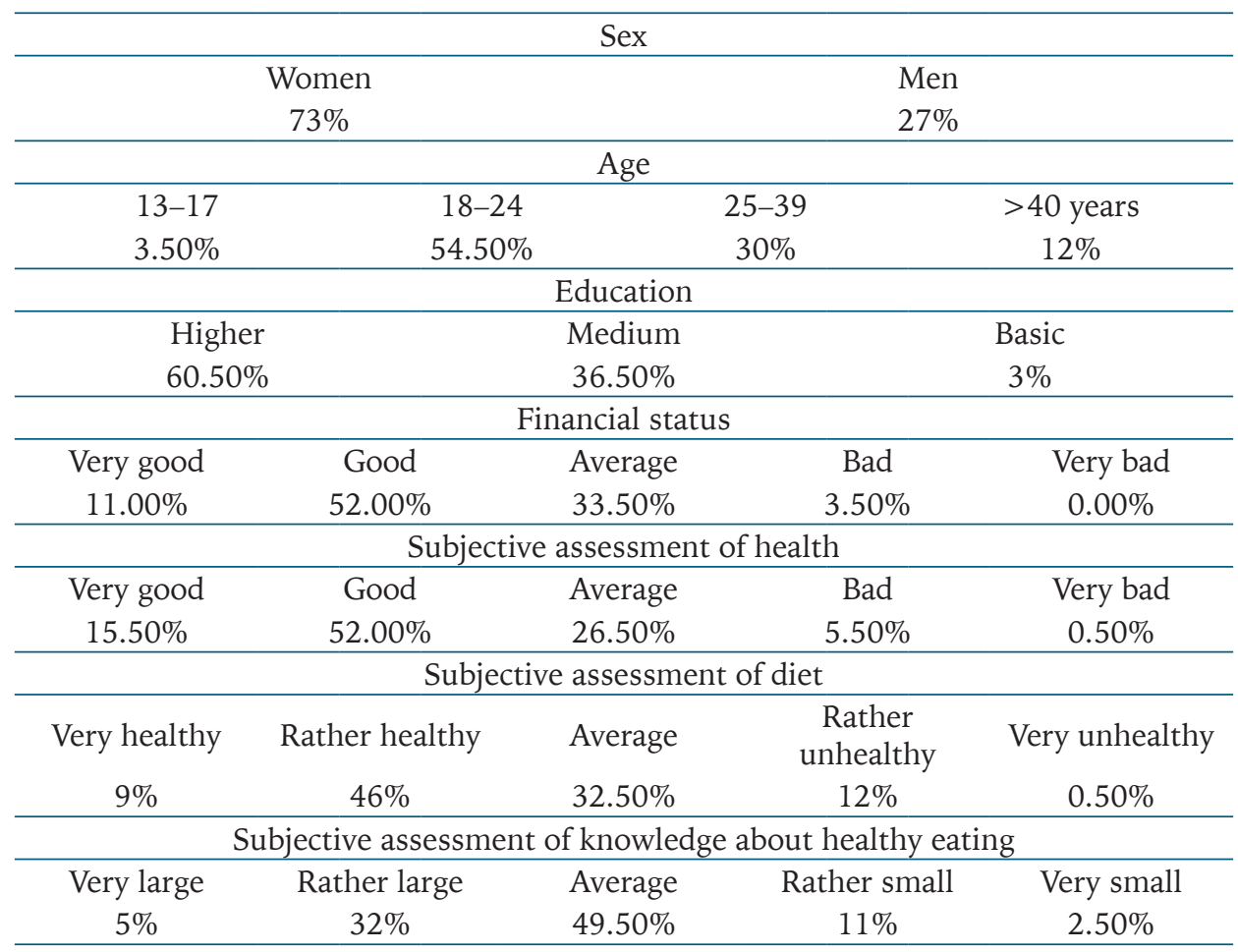

Source: The author's own study.

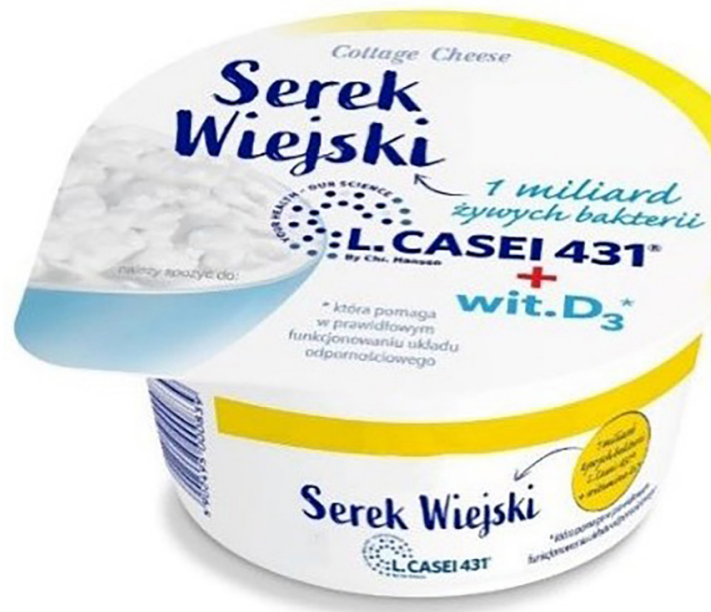

Fig. 1. Example of a product picture used in Part A of a research questionnaire Source: The author's own study. 
The study also addressed the interpretation of claims as separate messages not appearing on a specific product. Participants were asked to choose answers in the form of sentences that most accurately describe their feelings about a specific health or nutrition claim presented to them. For statements, any number of responses could be selected from:

1. It is worth buying this product;

2. The information is reliable to me;

3. The information is understandable to me;

4. This product is healthy;

5. This product is distasteful;

6. The information encourages the consumption of the product.

The survey form was completed by collecting basic data on respondents, such as age, education, financial situation or health status, all of which are of great importance for making food choices and purchasing decisions.

In order to obtain reliable results, the collected data were subjected to statistical tests. Statistical analysis was based, among other things, on the Pearson correlation test or the Student's t-test for two averages.

The differences in the assessment of the products depending on the claims made on them were statistically insignificant. However, for some products, the impact of the claims on the assessment was particularly evident:

- $83 \%$ of the sample rated their level of interest in healthy eating as medium and $20 \%$ as very high. The most important information for the respondents on food labels turned out to be: use-by date, the price of the product and nutritional information on the back of the packaging, such as the nutritional table or composition. Right behind them were: text and information contained on the front of the pack.

- $29 \%$ of respondents stated they always pay attention to the detailed information presented on the packaging of food products, $41 \%$ that they usually do it, while only $4 \%$ that they never do it.

Table 2. The highest and lowest product ratings due to the claim on them

\begin{tabular}{|c|c|c|c|c|}
\hline $\begin{array}{l}\text { Assessment } \\
\text { criterion }\end{array}$ & $\begin{array}{l}\text { Lowest } \\
\text { rating }\end{array}$ & Product & $\begin{array}{l}\text { Highest } \\
\text { rating }\end{array}$ & Product \\
\hline Healthiness & $\mathrm{C}$ & Chocolate bar & $\mathrm{NHC}$ & Cottage cheese \\
\hline Calorific value & $\mathrm{NHC}$ & Cottage cheese & \multirow{2}{*}{$\mathrm{C}$} & Chocolate bar \\
\hline Taste & \multirow{3}{*}{$\mathrm{HC}$} & Salt & & Fruit juice \\
\hline $\begin{array}{l}\text { Reliability of the information } \\
\text { contained on the label }\end{array}$ & & & & \\
\hline Willingness to purchase & & Chocolate bar & $\mathrm{NHC}$ & Oatmeal \\
\hline
\end{tabular}

Source: The author's own study

$\mathrm{HC}$ - group of health claims, NHC - group of nutrition and health claims, C - group without claims (Controlled).

In the group of nutritional claims, neither the lowest nor the highest ratings were recorded. 
Slightly more than half of the participants could not distinguish between a nutrition claim and a health claim, while the vast majority did not know what the real meaning of individual nutrition claims was.

Indicate the difference between claim types

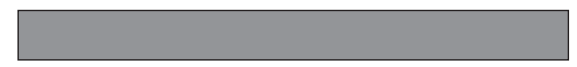

$42 \%$

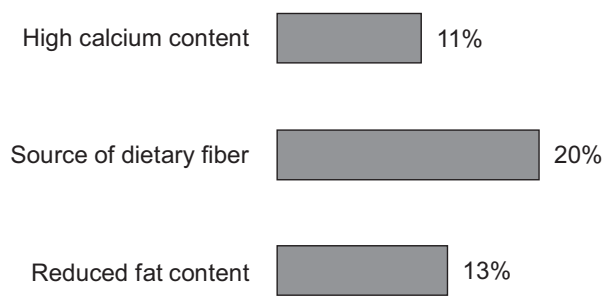

Reduced sugar content

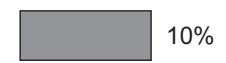

Fig. 2. Knowledge of claims among respondents

Source: Based on the author's own research.

It was also noted that respondents were sceptical of health-related information on food packaging. 36\%, which is the largest proportion, believed that placing such information on the label is regulated by law, but the rules are often violated by manufacturers.

Statements presented as separate messages were most often associated by respondents with a healthy product, and the least often indicated to them that the product is distasteful.

\section{Conclusions}

This study was one of the few on the impact of health and nutrition claims on the purchasing intentions of Polish food consumers. Similar research was conducted by Bryła in 2018. It is important to compare the results of these studies, especially since they were carried out in the periods before and after the COVID-19 pandemic (Bryła, 2020, pp. 177-214). In this research, for the vast majority of respondents health and nutrition claims were important when making purchasing decisions, and more than half of the respondents acknowledged that they were willing to pay more for products with claims. These results differ significantly from the results of this study. This is shown in Part A, which shows no major differences between the ratings of products with and without claims. Importantly, one of the evaluation criteria was the willingness to purchase the product.

There were also significant differences in the understanding and perception of the credibility of claims. In the research made in 2018, claims were understandable and rather reliable, while in this study, the understanding of claims 
was rather low, as was the perception of their credibility. However, the low level of respondents' knowledge about the statements did not affect the perception of their credibility (Bryła, 2020, pp. 177-214).

As in the study made in 2018 for respondents in this study, the most important information on food packaging was the expiration date and nutrient list. The perception of the importance of the claim has not differ either. In Bryla's study, health claims were indicated as slightly more important than nutrition claims and in this study the information on the back of the packaging (more often health claims) was according to respondents more important than those on the front (more often nutrition claims) (Bryła, 2020, pp. 177-214).

Thus, it can be concluded that in the last 3 years food consumers have become more sceptical about claims and their impact on purchasing decisions has decreased. These changes may have been influenced by the COVID-19 pandemic, which significantly affected the food market and consumer habits.

However, it should be noted, that in Bryła's study respondents were told beforehand what claims are, so these results may be more subjective than the results of this paper. In addition, the groups of respondents in both studies differed significantly in age and gender, average BMI, financial status and place of living (Bryła, 2020, pp. 177-214).

The characteristics of the study group were one of the limitations of this study. Only Polish food consumers participated in the study and most of them were women with good health, higher education and good financial status. The majority of respondents declared a high level of interest in healthy eating and at least average quality of diet. It is not known what the results would have been if the research had been conducted on respondents with other individual characteristics. It is also unclear how the results of this study translate into food purchases in real-world shop conditions. There is a need for more research with a larger and more diverse group of consumers and more similar to the real conditions of food purchases.

\section{References}

Annunziata A., Mariani A., 2019. Do Consumers Care about Nutrition and Health Claims? Some Evidence from Italy. Nutrients 11(11): 2735 (https://doi.org/10.3390/ nu11112735).

Bryła P., 2020. Oświadczenia zdrowotne i żywieniowe na rynku produktów żywnościowych. Wydawnictwo Uniwersytetu Łódzkiego, Łódź (https://doi.org/10.18778/8142872-9).

Chandon P., Wansink B., 2012. Does food marketing need to make us fat? A review and solutions. Nutrition Reviews 70(10): 571-593 (https://doi.org/10.1111/j.17534887.2012.00518.x).

Davidović D., Paunović K., Zarić D., Jovanović A., Vasiljević N., Stošović D., Tomanić M., 2021. Nutrition and Health Claims Spectra of Pre-Packaged Foods on Serbian Supermarket Shelves: A Repeated Cross-Sectional Study. Nutrients 13(8): 2832. (https:// doi.org/10.3390/nu13082832). 
De Boer A., 2021. Fifteen Years of Regulating Nutrition and Health Claims in Europe: The Past. the Present and the Future. Nutrients 13(5): 1725 (https://doi.org/10.3390/ nu13051725).

Hodgkins C.E., Egan B., Peacock M., Klepacz N., Miklavec K., Pravst I., Raats M.M., 2019. Understanding How Consumers Categorise Health Related Claims on Foods: A Consumer-Derived Typology of Health-Related Claims. Nutrients 11(3): 539 (https://doi. org/10.3390/nu11030539).

Lorenzoni G., Minto C., Temporin M., Fuscà E., Bolzon A., Piras G., Gregori D., 2019. (Ab)use of Health Claims in Websites: The Case of Italian Bottled Waters. International Journal of Environmental Research and Public Health 16(17): 3077 (https://doi. org/10.3390/ijerph16173077).

Lynam A., McKevitt A., Gibney M., 2011. Irish consumers' use and perception of nutrition and health claims. Public Health Nutrition 14(12): 2213-2219. (https://doi. org/10.1017/S1368980011000723).

Oostenbach L.H., Slits E., Robinson E., Sacks G., 2019. Systematic review of the impact of nutrition claims related to fat. Sugar and energy content on food choices and energy intake. BMC Public Health 19(1): 1296 (https://doi.org/10.1186/s12889-019-7622-3).

Regulation (EC) No 107/2008 of the European Parliament and of the Council of 15 January 2008 amending Regulation (EC) No 1924/2006 on nutrition and health claims made on foods as regards the implementing powers conferred on the Commission.

Regulation (EC) No 1924/2006 of the European Parliament and of the Council of 20 December 2006 on nutrition and health claims made on foods.

Shangguan S., Afshin A., Shulkin M., Ma W., Marsden D., Smith J., Food PRICE (Policy Review and Intervention Cost-Effectiveness) Project (2019). A Meta-Analysis of Food Labeling Effects on Consumer Diet Behaviors and Industry Practices. American Journal of Preventive Medicine 56(2): 300-314 (https://doi.org/10.1016/j.amepre.2018.09.024).

Steinhauser J., Hamm U., 2018. Consumer and product-specific characteristics influencing the effect of nutrition. health and risk reduction claims on preferences and purchase behavior - a systematic review. Appetite 127: 303-323 (https://doi.org/10.1016/j.appet.2018.05.012).

Steinhauser J., Janssen M., Hamm U., 2019. Who Buys Products with Nutrition and Health Claims? A Purchase Simulation with Eye Tracking on the Influence of Consumers' Nutrition Knowledge and Health Motivation. Nutrients 11(9): 2199 (https:// doi.org/10.3390/nu11092199).

Szymecka-Wesołowska A., 2011. Regulacja oświadczeń żywieniowych i zdrowotnych w Stanach Zjednoczonych. Przegląd Prawa Rolnego 2(9) (https://repozytorium. amu.edu.pl/bitstream/10593/2326/1/AGNIESZKA_SZYMECKA-WESOLOWSKA_199-223.pdf; access: 24.11.2021).

Szymura M., 2012. Oświadczenia żywieniowe i zdrowotne - aspekty prawne. Logistyka 4(2): 1308-1314 (https://www.logistyka.net.pl/bank-wiedzy/item/download/78499_1119627c77618e158a60e3ca3ceef5f5; access: 24.11.2021).

Talati Z., Pettigrew S., Neal B., Dixon H., Hughes C., Kelly B., Miller C. 2017. Consumers' responses to health claims in the context of other on-pack nutrition information: a systematic review. Nutrition Reviews 75(4): 260-273 (https://oi.org/10.1093/nutrit/ nuw070). 



\title{
Mirosław Pacut
}

\section{Consumers' preferences on the food market in selected European countries}

\begin{abstract}
Purpose: The purchasing behaviours of consumers are a phenomenon of significant dynamics, subject to significant changes, taking place along with changes in environmental factors, in particular, rapidly evolving technology and observed social changes. One of the key determinants shaping these behaviours are consumer preferences, which are also subject to significant modifications due to the trends observed in contemporary consumer societies. This phenomenon can be clearly observed, inter alia on the food market - especially in the context of healthy nutrition trends. The paper aims to identify and compare the purchasing preferences of food consumers in selected European countries in the context of healthy nutritional trends observed in contemporary consumer societies.

Design/methodology/approach: The analysis was based on the data provided by Euromonitor International (collected in the Euromonitor International's Lifestyles Survey). The data analysed covered the period 2015 to 2017 and concerned six European countries: France, Germany, Poland, Russia, Italy and the United Kingdom. It comprised comparisons of food consumers' pro- health preferences - made both in relation to individual elements/ingredients of purchased food products, and as a whole - using a synthetic index (calculated with the use of the taxonomic measure of distance to the benchmark).

Findings: The analysis revealed that food consumers' pro-health preferences show some differentiation in terms of their declared importance for consumers. The highest percentage of consumers declaring pro-health preferences was observed in the case of such attributes of food products as: natural ingredients, low sugar content and low calorie; while a lower percentage was observed in the case of sterilized food and trustworthy packaging. The synthetic index of pro-health food consumer preferences allowed the intensity of such preferences in analysed countries to be compared. The most pro-health preferences were declared in Poland, followed by Russia, France and Italy, while they were significantly weaker in the UK and Germany. However, the above analysis is subject to a certain reservation, resulting from a relatively low percentage of consumers declaring that they carefully read the nutritional tables on product labels (which seems to be a condition for making rational decisions about choosing healthy products). So it may indicate a discrepancy
\end{abstract}

SM - University of Economics in Katowice, College of Management, Department of Marketing • miroslaw.pacut@ue.katowice.pl • (D) https://orcid.org/0000-0001-6494-5167 
between the preferences declared by consumers in a survey and the ones actually manifested in their market choices.

Originality: The paper highlights the significance of healthy nutritional trends in shaping consumer preferences on contemporary food markets. The analysis shows the differences between the importance of individual attributes of food products perceived by consumers, as well as the differences between the intensity of pro-health consumer preferences, in six European countries.

Key words: consumer preferences, food markets, consumer behaviour, healthy food trends

\section{Introduction}

Turbulence - which is so characteristic of today's markets - causes the high dynamics of changes observed in the area of consumer purchasing behaviour, among other things. These changes occur with the development of external factors, especially such as fast-evolving information and communication technologies, social transformations or the COVID-19 pandemic, which generate global disturbances in the course of business cycles and force adjustments in the economic policies of most countries of the world. Significant changes in purchasing behaviours can be also observed in the food market - triggered by economic factors (such as price fluctuations) and social-cultural ones. The examples include trends concerning rational diets and healthy lifestyle, the fashion for being fit, and the growth of social awareness in the sphere of nutrition and ecology (a shift towards organic food, which is unprocessed and free of harmful ingredients, additives and preservatives, and towards sustainable food consumption). Customers thus look for food products of high nutritional value that are tailored to fit the needs of the human organism. They turn to natural food, which is little processed and which does not contain any artificial ingredients, additives or preservatives, and the same time avoid high-calorie foods, with high fat content and high levels of sugar or salt.

The aim of the paper is to compare the preferences of food buyers in the selected European countries in the context of healthy food trends observed in modern consumption societies. For analysis, we used data from Euromonitor International, based on the global study regularly conducted by this institution - Euromonitor International's Lifestyles Survey for the years 2015, 2016 and 2017 - concerning six European states: France, Germany, Poland, Russia, Italy and the United King$\mathrm{dom}^{1}$. On the basis of the obtained data, we compared the health-promoting preferences of food consumers, both regarding the individual elements/ingredients/ parameters of purchased products and holistically - comparing the values of the synthetic indicator of the healthfulness of preferences declared by consumers in the particular countries.

\footnotetext{
1 The reason behind the choice was the intention to analyse relatively diverse markets and the availability of data. The Euromonitor International's Lifestyles Survey has been carried out every year since 2011, but its scope has been changing over consecutive editions - the most recent data on food consumers' preferences is available for 2017.
} 


\section{Purchasing preferences as one of the key determinants of consumer behaviour in food markets}

Purchasing preferences are among the key factors determining the behaviour of consumers in the market. The concept of preferences - introduced to economics by V. Pareto - is usually defined as a set of the consumer's subjective evaluations and priorities (where some products, their types and brands, are valued more highly than others, creating a specific hierarchy of products belonging to the same category) that constitute the basis of choices made in the consumer decision process (Szymańska, 2012; Rudnicki, 2004; Czarny, 2006). Purchasing preferences do not always have to be equivalent to making a buying decision, but they are reflected in the acts of choosing material or immaterial goods, being revealed before or in the course of shopping and constituting one of the factors determining the choice of a specific product (Bajdak, 2005; Kaczmarczyk, 2006), or of such a sets of goods which maximize the usefulness and satisfaction generated by consuming them (Zawadzka, 2006). Regarding their relation to behaviours, preferences can be divided into expressed (declared by the consumer, concerning hypothetical behaviours) and revealed (concerning the consumer's actual behaviours) (Trojanek, 2009).

Consumers' preferences may stem from internal (psychological) factors or external (demographic, economic, social and cultural) ones - which is the basis for a division into internal and external preferences, respectively. Internal preferences are primarily shaped by declared choices, while external ones - by the actual market choices (O'Shaughnessy, 1994). Preferences thus reflect the consumer's tastes, likings and personality, but they are not only shaped by the internal factors of a psychological character. What is of equal importance are demographic factors (such as age, gender, stage in the family lifecycle, educational level), economic factors (income, wealth, market supply, prices) and socio-cultural ones (cultural norms, standards of affiliation and aspiration reference groups, the influence of opinion leaders, social fashions and trends) (Szymańska, 2012). As the result of permanent changes and revaluations in the area of the above factors, new trends in consumption behaviours have appeared. They are defined as the specific direction of changes in consumer preferences, being a consequence of transformations in the business environment (Zalega, 2013). The ongoing general consumption trends include ecologization and socially responsible consumption, as well as its virtualization, ethnocentrism, co-consumption, prosumption, consumerism, sustainable consumption, smart shopping, hyper-consumerism and luxury democratization (Sobczyk, 2018; Lemanowicz and Szwacka-Mokrzycka, 2019).

In the context of shaping the preferences of food buyers, the impact of socio-cultural factors may be a particularly interesting subject of analysis - because of the multi-aspect influence of this sphere on changes in consumers' dietary patterns, manifesting themselves in following global nutrition trends, among other things (Bylok, 2018). Among the determinants of these trends are religious-philosophical aspects (e.g., vegetarianism, the elimination of some kinds of meat), 
ethical-moral issues (e.g., taking care of the well-being of animals in the process of food production), ecological factors (e.g., sustainable consumption, zero waste), but the most important factor determining the contemporary food trends are health aspects (Gadzała and Lesiów, 2019), which is partly the effect of the general increase in the nutritional awareness of societies (Goryńska-Goldmann and Ratajczak, 2010). Health-promoting food trends mostly involve a reduction in the consumption of high-calorie products (Gniedziejko and Lesiów, 2018), high-fat foods (Hamilton et al., 2000) (particularly hydrogenated fats) (Dhaka et al., 2011), sugar (Yeo et al., 2020), and salt (Denver et al., 2021), while at the same time preferring organic food, free of chemical additives (Hemmerling et al., 2016) and food processed and packaged in a way that is safe for health - without physical and biological food contamination (Żbikowska et al., 2019). Other, less obvious expressions of health-promoting dietary trends include the avoidance of ingredients whose harmfulness to the human body has not been verified yet - such as genetically modified food (Rodriguez-Entrena and Sayadi, 2013), or products containing gluten, lactose (Gadziała and Lesiow, 2019), or monosodium glutamate (MSG) (Wang and Adhikari, 2018).

Consumer preferences in the food market have been the subject of numerous research projects, both on the nationwide and international scale, covering both attempts to identify preferences regarding the food industry (Świetlik, 2017; Grzybowska-Brzezińska, 2018) and specific studies concerning particular product ranges (Cichocka et al., 2016; Mehta and Bhanja, 2018), individual products (Połom and Baryłko-Piekielna, 2004; Haghiri, 2014) or even the elements of products and packaging (Białek and Kondratowicz-Pietruszka, 2015; Arboretti and Bordignon, 2016) or brands (Maciejewski et al., 2018; Anselmsson et al., 2008). It should be pointed out that these studies concerned preferences within specific socio-geographical groups (Dioszegi et al., 2019), food types (Bilska et al., 2017; Janiak et al., 2016), quality aspects (Pagliuca and Scarpato, 2011) and food origin (Savelli et al., 2021; Yijun et al., 2015). Another important line of study in the area of consumption preferences in food markets is research into nutrition trends affecting changes in these preferences (Jeżewska-Zychowicz, 2015; Stevens, 1993; Casini et al., 2015; Pindado and Barrena, 2020; Lemanowicz and Szwacka-Mokrzycka, 2019; Gadziała and Lesiów, 2019).

\section{Consumers' health-promoting preferences in the food markets of selected European countries}

In order to identify and compare the consumption preferences of food buyers in particular countries, we used an analysis of data accessed from Euromonitor International, obtained within the framework of the global periodic study, Euromonitor International's Lifestyles Survey, which covers multiple and diverse aspects reflecting the observed lifestyles of modern societies - including habits related to declared preferences regarding the consumption of food products, among other things, in the context of its health-promoting attributes. 
The fundamental issue to be analysed in the above context are declared preferences concerning organic food, which does not contain artificial ingredients and additives. Such preferences are expressed by slightly less than a half of consumers in the examined countries (Table 1, Table 2), with significant differences between them - the high percentage of Russians preferring ecological food is worth attention (approx. 60-70\%); the high share of such preferences is also observed in Poland and France (expressed by about a half of the respondents); in the other countries this indicator is lower. These values are generally stable throughout the period under study (the years 2015-2017).

Table 1. Declared preferences regarding the purchase of food containing only natural ingredients (in \%)

\begin{tabular}{lccc}
\hline \multicolumn{1}{c}{ Country } & 2015 & 2016 & 2017 \\
\hline France & 35.0 & 41.2 & 45.1 \\
Germany & 34.4 & 33.6 & 33.2 \\
Poland & N/A & 44.8 & 46.7 \\
Russia & 65.5 & 70.3 & 71.4 \\
Great Britain & 29.3 & 31.5 & 31.6 \\
Italy & N/A & 47.7 & 51.9 \\
\hline
\end{tabular}

Source: The author's own work, based on Euromonitor International data.

Table 2. Declared preferences regarding the purchase of food containing few artificial additives/ingredients (in \%)

\begin{tabular}{llll}
\hline \multicolumn{1}{c}{ Country } & 2015 & 2016 & 2017 \\
\hline France & 35.3 & 43.1 & 43.6 \\
Germany & 43.0 & 45.3 & 45.0 \\
Poland & N/A & 55.8 & 55.0 \\
Russia & 48.6 & 57.3 & 59.6 \\
Great Britain & 36.7 & 40.8 & 37.8 \\
Italy & N/A & 42.1 & 40.7 \\
\hline
\end{tabular}

Source: The author's own work, based on Euromonitor International data.

In order to recognize the particular ingredients of food articles as natural or artificial, the consumer needs to know them (Table 3). The percentage of consumers declaring that they purchase food products containing only ingredients familiar to them amounts to a little more than $20 \%$ in France, Germany and the UK and is higher in Italy and Poland (approx. 35\%) and Russia (over 40\%).

One of the basic indicators of health-promoting preferences regarding the purchase of food products is their low-calorie content (Table 4). In this case, the percentage of consumers declaring such preferences does not vary across the examined countries, assuming the values from $1 / 4$ to $1 / 3$, being the lowest in Russia (24\%) and the highest in Italy - (almost 37\%). 
Table 3. Declared preferences regarding the purchase of food containing only ingredients familiar to the consumer (in \%)

\begin{tabular}{llll}
\hline \multicolumn{1}{c}{ Country } & 2015 & 2016 & 2017 \\
\hline France & 20.7 & 24.5 & 22.4 \\
Germany & 24.5 & 24.2 & 23.6 \\
Poland & N/A & 33.4 & 35.1 \\
Russia & 39.9 & 43.9 & 41.6 \\
Great Britain & 20.9 & 22.1 & 22.6 \\
Italy & N/A & 38.1 & 35.7 \\
\hline
\end{tabular}

Source: The author's own work, based on Euromonitor International data.

Table 4. Declared preferences regarding the purchase of food with low-calorie content (in $\%)$

\begin{tabular}{llll}
\hline \multicolumn{1}{c}{ Country } & 2015 & 2016 & 2017 \\
\hline France & 23.8 & 25.1 & 26.8 \\
Germany & 26.9 & 27.5 & 28.5 \\
Poland & N/A & 32.4 & 31.2 \\
Russia & 23.0 & 26.1 & 24.0 \\
Great Britain & 30.1 & 29.7 & 31.9 \\
Italy & N/A & 36.1 & 36.8 \\
\hline
\end{tabular}

Source: The author's own work, based on Euromonitor International data.

The percentage of consumers avoiding high-fat products is a lot higher than in the case of high-calorie food. We can see more significant differences among the examined countries here (Table 5). The lowest percentage of consumers preferring low-fat food is observed in Russia (slightly below 30\%, although it should be stressed that it considerably increases over the period under analysis), it is a bit higher in Germany (approx. 1/3), with considerably higher values in the other countries (around 40\%). It must be emphasized here that this indicator significantly increased in most countries (except for Germany and the United Kingdom) in the years 2015-2017.

Table 5. Declared preferences regarding the purchase of low-fat foods (in \%)

\begin{tabular}{lccc}
\hline \multicolumn{1}{c}{ Country } & 2015 & 2016 & 2017 \\
\hline France & 39.6 & 41.8 & 43.1 \\
Germany & 33.4 & 36.6 & 33.7 \\
Poland & N/A & 39.8 & 42.8 \\
Russia & 23.2 & 25.8 & 28.2 \\
Great Britain & 41.7 & 37.2 & 38.9 \\
Italy & N/A & 39.5 & 41.8 \\
\hline
\end{tabular}

Source: The author's own work, based on Euromonitor International data. 
The preference for low-sugar foods is another significant indicator from the point of view of health-promoting nutrition trends (Table 6). The percentage of consumers declaring the daily purchase of such products fluctuates around or slightly exceeds $50 \%$ (the indicator is the highest in Poland -55\%). Considerably lower values are observed only in Italy (38\%) and Russia (29\%). It should also be stressed that the indicator rises throughout the examined period in France and Poland.

Table 6. Declared preferences regarding the purchase of low-sugar foods (in \%)

\begin{tabular}{lccc}
\hline \multicolumn{1}{c}{ Country } & 2015 & 2016 & 2017 \\
\hline France & 44.5 & 48.0 & 49.0 \\
Germany & 42.3 & 45.8 & 44.9 \\
Poland & N/A & 50.7 & 55.3 \\
Russia & 21.9 & 27.4 & 29.2 \\
Great Britain & 51.0 & 50.3 & 51.2 \\
Italy & N/A & 39.4 & 37.6 \\
\hline
\end{tabular}

Source: The author's own work, based on Euromonitor International data.

There is a similar situation with regard to the declared preferences of low-sodium foods (Table 7). Here, we can also observe clear differences among the analysed countries. The indicator stands at only $17 \%$ in Russia and $18 \%$ in Italy, being only slightly higher in Italy $(24 \%)$. In the other countries low-sodium food products are preferred by about $40 \%$ consumers (the largest share is in the United Kingdom - almost 43\%).

Table 7. Declared preferences regarding the purchase of low-sodium foods (in \%)

\begin{tabular}{lccc}
\hline \multicolumn{1}{c}{ Country } & 2015 & 2016 & 2017 \\
\hline France & 36.6 & 38.3 & 41.3 \\
Germany & 19.0 & 19.8 & 18.0 \\
Poland & N/A & 37.5 & 39.2 \\
Russia & 12.6 & 17.0 & 17.1 \\
Great Britain & 43.9 & 41.4 & 42.9 \\
Italy & N/A & 29.0 & 24.0 \\
\hline
\end{tabular}

Source: The author's own work, based on Euromonitor International data.

Undoubtedly one of the most important requirements of healthy diet is the reduction of unsaturated fatty acids, which is produced in the process of partial hardening (hydrogenation) of fat oils. Preferences in this respect significantly vary among the examined countries (data only for 2015, no data for Poland and Italy) (Table 8). It was Russia where the percentage of such declared preferences was the highest (almost a half of consumers avoid partially hydrogenated fats), while the lowest value was observed in Germany (about 1/5 of the respondents declaring such preferences). 
Table 8. Declared preferences regarding the purchase of food not containing trans fatty and partially hardened (hydrogenated) fat oils (in \%)

\begin{tabular}{lc}
\hline \multicolumn{1}{c}{ Country } & $2015^{*}$ \\
\hline France & 33.1 \\
Germany & 19.8 \\
Poland & N/A \\
Russia & 48.4 \\
Great Britain & 27.2 \\
Italy & N/A \\
\hline
\end{tabular}

Source: The author's own work, based on Euromonitor International data.

* the question on preferences concerning trans fatty and partially hardened fat oils was not included in the 2016 and 2017 editions of the Euromonitor International's Lifestyles Survey.

Another key element of the health safety of food is the way it is processed (eliminating biological contamination) and packaged. However, the percentage of consumers preferring sterilized food (e.g., in the pasteurization process) in the analysed countries is relatively low in general (Table 9). The highest level is reported in Poland and Russia (a little more than 20\%) and Italy, while it does not exceed a few per cent in the remaining countries. It should be added that the percentage of the declared preferences of sterilized food slightly drops in all the examined countries.

Table 9. Declared preferences regarding the purchase of pasteurized or differently processed food (in \%)

\begin{tabular}{lrrr}
\hline \multicolumn{1}{c}{ Country } & 2015 & 2016 & 2017 \\
\hline France & 5.7 & 5.4 & 4.8 \\
Germany & 6.4 & 6.7 & 6.2 \\
Poland & N/A & 20.6 & 18.3 \\
Russia & 17.0 & 18.2 & 17.8 \\
Great Britain & 4.3 & 3.7 & 3.4 \\
Italy & N/A & 15.5 & 13.5 \\
\hline
\end{tabular}

Source: The author's own work, based on Euromonitor International data.

The indicator of declared preferences with regard to the safe, trustworthy packaging of food products is slightly higher (Table 10). Just as in the previous case, Russia holds the leading position here (more than $1 / 3$ of consumers indicating such preferences), followed by Poland and Russia (about 1/4), while the lowest value of this measure is observed in Germany (below 10\%).

Another clear expression of pro-health preferences with reference to purchasing food is also the choice of products recommended by health promotion organizations (Table 11). Such recommendations have the strongest influence on consumers' preferences in Russia (almost 40\%) and are relatively strong in Poland (approx. 1/4), while in the remaining countries the indicator is not higher than a dozen or so per cent. 
Table 10. Declared preferences regarding the purchase of food packaged in a trustworthy manner (in \%)

\begin{tabular}{lrrr}
\hline \multicolumn{1}{c}{ Country } & 2015 & 2016 & 2017 \\
\hline France & 22.1 & 24.1 & 24.5 \\
Germany & 9.9 & 9.2 & 9.3 \\
Poland & $\mathrm{N} / \mathrm{A}$ & 26.1 & 22.4 \\
Russia & 35.7 & 35.4 & 36.5 \\
Great Britain & 14.1 & 14.0 & 13.1 \\
Italy & $\mathrm{N} / \mathrm{A}$ & 16.3 & 16.5 \\
\hline
\end{tabular}

Source: The author's own work, based on Euromonitor International data.

Table 11. Declared preferences regarding the purchase of food recommended by a health promotion organization (in \%)

\begin{tabular}{lrrr}
\hline \multicolumn{1}{c}{ Country } & 2015 & 2016 & 2017 \\
\hline France & 9.9 & 11.7 & 12.6 \\
Germany & 9.2 & 9.5 & 11.0 \\
Poland & $\mathrm{N} / \mathrm{A}$ & 26.2 & 23.5 \\
Russia & 36.5 & 38.4 & 38.3 \\
Great Britain & 7.0 & 8.7 & 10.9 \\
Italy & $\mathrm{N} / \mathrm{A}$ & 16.7 & 16.6 \\
\hline
\end{tabular}

Source: The author's own work, based on Euromonitor International data.

On the sidelines of the main discussion, it is worth paying attention to the ingredients whose influence on the health aspect of food has not been verified yet. Nevertheless, they are considered to be controversial - some people believe that they should be eliminated from our daily diet for health reasons. This is reflected in the observed trends or even fashions for foods that are gluten-free, free of genetic modification, or which do not contain monosodium glutamate. It is genetically modified food that meets the biggest resistance: in Russia, 2/3 of all consumers prefer GMO-free products, in Germany and France - more than

Table 12. Declared preferences regarding the purchase of GMO-, gluten- and MSG-free food (2015)

\begin{tabular}{lccc}
\hline \multirow{2}{*}{ Country } & \multicolumn{3}{c}{ Declared preferences regarding food products (in \%) } \\
\cline { 2 - 4 } & GMO-free & gluten-free & MSG-free \\
\hline France & 42.0 & 7.2 & 13.4 \\
Germany & 35.6 & 10.8 & 14.4 \\
Poland & N/A & N/A & N/A \\
Russia & 66.6 & 21.6 & 44.2 \\
Great Britain & 18.7 & 5.7 & 19.3 \\
Italy & N/A & N/A & N/A \\
\hline
\end{tabular}

Source: The author's own work, based on Euromonitor International data. 
$1 / 3$, while relative indifference towards genetically modified additives is observed in the UK, where only every fifth consumer declares avoiding such foods (Table 12). With reference to MSG, it is Russia again that reports the highest percentage of people preferring food devoid of this additive (over 40\%), while in the other countries the indicator does not exceed a dozen or so per cent.

In order to obtain a general picture of the level of health-promoting preferences of food buyers in the particular countries, we calculated the synthetic measure of the "healthfulness' of preferences declared by consumers. To devise the indicator, we focused on variables describing the percentage of preferences with regard to, respectively: exclusively natural food ingredients, the low level of artificial additives, the content of only those ingredients which are familiar to the consumer, low-calorie content, low-sodium, the reduced content of partially hydrogenated fat oils, sterilized food, properly packaged food, and food recommended by a health promotion organization. The first two of the above variables (preferences for exclusively natural food ingredients and the low level of artificial additives) as they actually refer to the same preferences and would have too much weight - were replaced with one variable calculated as their arithmetic mean.

The value of the synthetic indicator was calculated with the application of the taxonomic method of measuring distance from the pattern. As the pattern values, we selected the maximum values obtained for each variable as of 2017 (with the exception of the variable describing preferences with regard to partially hydrogenated fat oils, where the data concerned only 2015 and did not cover Italy and Poland - in the case of these countries, the value of the variable was adopted as the arithmetic mean of the values for the other states).

In calculating the distance from the pattern, we applied the measure of Euclidean distance, estimated for n-dimensional space as:

$$
d(p, q)=\sqrt{\left(p_{1}-q_{1}\right)^{2}+\left(p_{2}-q_{2}\right)^{2}+\ldots+\left(p_{i}-q_{i}\right)^{2}+\ldots+\left(p_{n}-q_{n}\right)^{2}}
$$

where: $d$ - Euclidean distance between observations $p$ and $q ; p_{1} \ldots n, q_{1} \ldots n$-variable values $1 \ldots n$ for observations $p$ and $q$.

The estimated synthetic indicator has values from 31.39 to 66.00 , where the higher value means the bigger distance from the pattern (i.e., less intensity of declared health- promoting consumption preferences). Hence, the strongest health-promoting declared preferences with regard to the purchase of food products can be observed among Polish consumers, followed by Russian, French and Italian buyers, while the weakest can be seen among consumers from the United Kingdom and especially Germany (Table 13).

In the context of the above considerations, one reservation should be made. It is unknown to what degree consumers' declared preferences translate into their actual behaviours. The analysis of data concerning the percentage of people who really familiarize themselves with the tables of food nutrients raises doubts whether this is the case. As few as $20 \%$ to $40 \%$ of the respondents declare that they carefully read these tables - the largest number in Russia (approx. 40\%), the 
Table 13. The value of the synthetic indicator of distance from the pattern of preferences regarding the purchase of healthy food (in \%)

\begin{tabular}{lc}
\hline \multicolumn{1}{c}{ Country } & Synthetic indicator of distance from the pattern \\
\hline France & 46.68 \\
Germany & 66.00 \\
Poland & 31.39 \\
Russia & 41.63 \\
Great Britain & 57.77 \\
Italy & 47.28 \\
\hline
\end{tabular}

Source: The author's own work, based on Euromonitor International data.

smallest in the United Kingdom (about 20\%). Therefore, the data concerning consumers' declared health-promoting preferences must be approached with caution since it seems obvious that without becoming acquainted with the information on the content and nutritional values of a product it is difficult, if not impossible at all, to make a rational decision about the healthfulness of particular products (Table 14). It is thus likely that the revealed (actual) preferences may be far from the declared ones.

Table 14. The percentage of consumers who carefully read the tables of food nutrients on the labels of food articles (in \%)

\begin{tabular}{llll}
\hline \multicolumn{1}{c}{ Country } & 2015 & 2016 & 2017 \\
\hline France & 29.6 & 26.6 & 24.2 \\
Germany & 27.3 & 25.3 & 22.1 \\
Poland & N/A & 33.6 & 28.4 \\
Russia & 47.4 & 45.8 & 40.2 \\
Great Britain & 22.2 & 20.9 & 19.7 \\
Italy & N/A & 33.8 & 27.3 \\
\hline
\end{tabular}

Source: The author's own work, based on Euromonitor International data.

\section{Conclusions}

Purchasing preferences constitute an important determinant of consumer behaviour, at the same time being subject to dynamic changes, which are a consequence of permanent transformations in the business environment. This is reflected in, among other things, new trends in consumption behaviour, defined as a specific direction of changes in buyers' preferences, including those concerning the consumption of food products. Among the trends that have the strongest impact on changes of preferences in this respect are tendencies to adopt health-promoting values as the criterion of market choices. In order to identify and compare the consumption preferences of food buyers, we analysed the declared health-promoting preferences in six European countries - demonstrating that they differ in terms of declared relevance for consumers. The highest percentage of consumers 
declaring pro-health preferences was observed with regard to such attributes of food products as natural ingredients, low-sugar and low-calorie content; while a lower percentage was observed with reference to sterilized food and trustworthy packaging.

In order to compare the level of food consumers' health-promoting preferences in the selected countries, we estimated the synthetic indicator of the "healthfulness" of declared preferences, calculated with the use of the taxonomic method of measuring distance from the pattern. The strongest health-promoting preferences with regard to the purchase of food products were declared by Polish consumers, followed by Russian, French and Italian ones, while the weakest can be seen among British and especially German buyers. To conclude our analysis, however, we must make one reservation, which stems from quite a low percentage of consumers declaring their familiarity with the tables of food nutrients. This seems to be the condition for making rational decisions regarding the choice of healthy products; thus, there may be a discrepancy between the preferences declared in the study and those actually revealed in the market.

\section{References}

Anselmsson J., Johansson U., Persson N., 2008. The battle of brands in the Swedish market for consumer packaged food: A cross-category examination of brand preference and liking. Journal of Brand Management 16(1-2): 63-79.

Arboretti R., Bordignon P., 2016. Consumer preferences in food packaging: CUB models and conjoint analysis. British Food Journal 118(3): 527-540.

Bajdak A., 2005. Preferencje nabywców instytucjonalnych - metody badania. Prace Naukowe Akademii Ekonomicznej w Katowicach, Katowice.

Białek J., Kondratowicz-Pietruszka E., 2015. Preferencje konsumentów w zakresie wyboru opakowań tłuszczów roślinnych Zeszyty Naukowe Akademii Morskiej w Gdyni 88: 182-187.

Bilska A., Malant M., Danyluk B., Kowalski R., 2017. Preferencje konsumentów w zakresie żywności tradycyjnej i regionalnej. Nauka, Przyroda, Technologie 11(1): 45-54.

Bylok F., 2018. Społeczne aspekty konsumpcji żywności - socjologiczna perspektywa. Handel Wewnętrzny 1(372): 5-16.

Casini L., Contini C., Romano C., Scozzafava G., 2015. Trends in food consumptions: what is happening to generation X? British Food Journal 117(2): 705-718.

Cichocka I., Krupa J., Shypot A., 2016. Organic food in the commercial offer and consumer preferences while purchasing it. Journal of Agrobusiness and Rural Development 3(41): 273-281.

Czarny E., 2006. Mikroekonomia. Polskie Wydawnictwo Ekonomiczne, Warszawa.

Denver S., Christensen T., Nordström J., 2021. Consumer preferences for low-salt foods: a Danish case study based on a comprehensive supermarket intervention. Public Health Nutrition 24(12): 3956-3965.

Dhaka V., Gulia N., Ahlawat K., Singh K., Bhupender S., 2011. Trans fats-sources, health risks and alternative approach - A review. Journal of Food Science and Technology 48(5): 534-541.

Diószegi J., Pikó P., Kósa Z., Sándor J., Ádány R., 2019. Taste and food preferences of the Hungarian Roma population. European Journal of Public Health suppl. 4, 29. 
Gadzała K., Lesiow T., 2019. Wybrane aktualne trendy żywieniowe. Praca przeglądowa. Nauki Inżynierskie i Technologie 2(33): 9-25.

Gniedziejko M., Lesiów T., 2018. Zachowania konsumenckie związane z wyborem mlecznych produktów light i ich uwarunkowania. Nauki Inżynierskie i Technologie 4(31): 31-51.

Goryńska-Goldmann E., Ratajczak P. (2010). Świadomość żywieniowa a zachowania żywieniowe konsumentów. Journal of Agribusiness and Rural Development 4(18): 4148.

Grzybowska-Brzezińska M., 2018. Preferencje konsumentów wobec atrybutów produktów żywnościowych. Handel Wewnętrzny 3(374): 184-196.

Haghiri M., (2014). An evaluation of consumers' preferences for certified farmed Atlantic salmon. British Food Journal 116(7): 1092-1105.

Hamilton J., Knox B., Hill D., Parr H., 2000. Reduced fat products - Consumer perceptions and preferences. British Food Journal 102(7): 494-506.

Janiak E., Orzechowska-Przybyła K., Lesiów T., 2016. Analysis of knowledge and consumer preferences in the field of organic food. Engineering Sciences \& Technologies 1(20): 43-58.

Jeżewska-Zychowicz M., 2015. Czynniki determinujące gotowość konsumentów do nabywania żywności prozdrowotnej. Handel Wewnętrzny 3(356): 90-99.

Kaczmarczyk S., 2006. Zastosowania badań marketingowych. Zarządzanie marketingowe i otoczenie przedsiębiorstwa. Wydawnictwo PWE, Warszawa.

Lemanowicz M., Szwacka-Mokrzycka J., 2019. Identification of leading consumer trends on the food market. Economic Science for Rural Development Conference Proceedings 51: 291-297.

Maciejewski G., Mokrysz S., Wróblewski Ł., 2018. Preferencje konsumentów wobec marek kaw dostępnych na polskim rynku - analiza porównawcza. Marketing i Rynek 24: 27-39.

Mehta R., Bhanja N., 2018. Consumer preferences for wine attributes in an emerging market. International Journal of Retail \& Distribution Management 46(1): 34-48.

O’Shaughnessy J., 1994. Dlaczego ludzie kupują. PWE, Warszawa.

Pagliuca M.M., Scarpato D., 2011. Food quality, consumer perception and preferences: an analysis on olive oil. Electronic Journal of Applied Statistical Analysis 4(2): 215-226.

Pindado E., Barrena R., 2020. Using Twitter to explore consumers' sentiments and their social representations towards new food trends. British Food Journal 123(3): 10601082.

Połom A., Baryłko-Pikielna N., 2004. Analiza czynników decydujących o preferencjach polskich konsumentów mięsa wieprzowego. Żywność. Nauka. Technologia. Jakość 3(40): 7-23.

Rodríguez-Entrena M., Sayadi S., 2013. Analyzing consumers' preferences towards GM food in southern Spain. New Genetics \& Society 32(1): 18-36.

Rudnicki L., (2004). Zachowania rynkowe nabywców. Mechanizmy i uwarunkowania. Wydawnictwo Akademii Ekonomicznej w Krakowie, Kraków.

Savelli E., Bravi L., Francioni B., Murmura F., Tonino P., 2021. PDO labels and food preferences: results from a sensory analysis. British Food Journal 123(3): 1170-1189.

Sobczyk G., 2018. Zachowania konsumentów wobec nowych trendów konsumpcji - wyniki badań. Annales Universitatis Mariae Curie-Skłodowska 52(1): 171-180.

Stevens G.L., 1993. Food Trends and the Changing Consumer. The Journal of Consumer Affairs 27(1): 202.

Szymańska A.I., 2012. Preferencje konsumenckie i ich determinanty. Zeszyty Naukowe Wyższej Szkoły Ekonomii i Informatyki w Krakowie 8: 67-86. 
Świetlik K., 2017. Preferencje konsumentów na rynku żywności w Polsce w warunkach deflacji w latach 2014-2015. Zeszyty Naukowe SGGW - Ekonomika i Organizacja Gospodarki Żywnościowej 117: 75-92.

Trojanek M., 2009. Preferencje nabywców na pierwotnym rynku mieszkaniowym w Poznaniu. Acta Scientiarum Polonorum, Administratio Locorum 8(1): 5-19.

Varian H.R., 2005. Mikroekonomia. Kurs średni - ujęcie nowoczesne. Wydawnictwo Naukowe PWN, Warszawa.

Yeo G., Cho M., Oh J., 2020. Food-related lifestyle segmentation and beverage attribute' selection: toward understanding of sugar-reduced beverages choice. British Food Journal 122(12): 3663-3677.

Yijun H., Suyun L., Nan J., 2015. Chinese Consumers' Awareness, Preferences and Purchasing Behavior on Korean Food. Asian Agricultural Research 7(8): 16-21.

Zalega T., 2013. Nowe trendy w zachowaniach konsumpcyjnych miejskich gospodarstw domowych w okresie kryzysu. Marketing i Rynek 8: 24-31.

Zawadzka Z., 2006. Podstawy teorii zachowań konsumenta, [in:] S. Marciniak (ed.), Makro- i mikroekonomia. Podstawowe problemy współczesności. PWN, Warszawa, pp. $254-275$.

Żbikowska A., Mendryk A., Onacik-Gür S., Marciniak-Łukasiak K., Szymańska I., 2019. Analiza opinii konsumentów na temat bezpieczeństwa opakowań do żywności. Badania wstępne. Nauki Inżynierskie i Technologie 1(32): 58-69. 


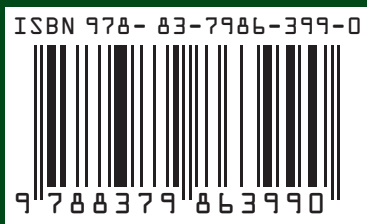

